\author{
UNIVERSIDADE DE SÃO PAULO \\ FACULDADE DE CIÊNCIAS FARMACÊUTICAS \\ Programa de Pós-Graduação em Farmácia \\ Área de Análises Clínicas
}

\title{
Fatores de virulência e genes regulatórios agr de Staphylococcus aureus e outras espécies coagulase positivas isoladas de mastites bovina e ovina
}

Lara Mendes de Almeida

Dissertação para obtenção do grau de MESTRE

Orientadora: Prof ${ }^{\mathrm{a}}$ Dra. Elsa Masae Mamizuka

São Paulo 
Lara Mendes de Almeida

Fatores de virulência e genes regulatórios agr de Staphylococcus aureus e outras espécies coagulase positivas isoladas de mastites bovina e ovina

Comissão julgadora da dissertação para obtenção do grau de Mestre

Prof $f^{a}$ Dra. Elsa Masae Mamizuka

Orientador/ presidente

$1^{\mathrm{o}}$ examinador

$2^{\circ}$ examinador

São Paulo, de

de 2009 . 
Ao Carlos 
Aos meus filhos, Natalie e Felipe 


\section{Agradecimentos}

À Prof ${ }^{a}$ Dra. Elsa Masae Mamizuka, pela oportunidade, por sua orientação sempre paciente e pela compreensão e carinho em momentos difíceis.

Aos veterinários Franklin Bispo dos Santos, sua orientadora Prof ${ }^{\mathrm{a}}$ Titular Elizabeth Oliveira da Costa e ao Prof. Doutor Luiz Francisco Zafalon pela coleta e disponibilidade das amostras provenientes de bovinos do Estado de SP analisadas neste estudo. À Prof ${ }^{a}$ Doutora Carla Lopes de Mendonça (UFRPE), pelas amostras de ovinos da região do agreste do Estado de $\mathrm{PE}$.

Ao John Anthony McCulloch, por suas explicações sempre claras e problematizadoras, por ter compartilhado o trabalho de padronização de suas técnicas e pela colaboração em alguns ensaios dessa pesquisa.

Ao Nilton Lincopan, por questionar, algumas vezes, o foco e os meios de desenvolvimento dessa pesquisa, sugerindo outros caminhos interessantes e por sua generosidade no dia a dia.

À Prof $f^{a}$ Marina Martinez, por suas aulas no curso de Microbiologia que me incentivaram a voltar à pesquisa. Aos seus alunos, Ana Carolina, Elisabeth, Carla, Renata e Lucas pelo apoio na realização de muitos experimentos.

À banca examinadora de qualificação, composta pelo Prof. Luiz Francisco Zafalon e pela Prof ${ }^{a}$ Maria de Lourdes Ribeiro de Souza da Cunha, pelas leituras cuidadosas e sugestões.

À Renata Pacheco, pela generosidade ao compartilhar técnicas bem padronizadas.

Aos meus colegas de laboratório, Mariama, Mónica, Álvaro, Charline, Patrícia, Lilian e Franciele pelo convívio carinhoso e pelas possibilidades de troca. 
Ao meu pai, Fernando, pelas conversas sobre Ciências Naturais, e à Rose.

À minha mãe, Fátima e ao Djalma.

Aos funcionários do departamento, pelo atendimento a inúmeras solicitações administrativas e pela ajuda na organização do laboratório.

Ao CNPq, pelo auxílio financeiro para a realização deste estudo. 


\section{Lista de abreviaturas e siglas}

\begin{tabular}{|c|c|}
\hline agr & Regulador de Genes Acessórios \\
\hline AIP & Peptídeo Auto-indutor \\
\hline APC & Célula Apresentadora de Antígeno \\
\hline BAP & Proteína associada à formação de biofilme \\
\hline bap & Gene codificador da proteína associada à formação de biofilme \\
\hline BBP & Proteína ligadora de sialoproteína óssea \\
\hline$b b p$ & Gene codificador da proteína ligadora de sialoproteína óssea \\
\hline BHI & Infusão de Coração e Cérebro \\
\hline BORSA & Borderline Oxacillin-Resistant Staphylococcus aureus \\
\hline CCS & Contagem das Células Somáticas \\
\hline CIM & Concentração Inibitória Mínima \\
\hline CLFA & Clumping factor A \\
\hline clfA & Gene codificador do Clumping factor A \\
\hline CLFB & Clumping factor B \\
\hline clfB & Gene codificador do Clumping factor B \\
\hline CLSI & Clinical and Laboratory Standards Institute \\
\hline CMT & California Mastitis Test \\
\hline CNA & Proteína ligadora de colágeno \\
\hline cna & Gene codificador da proteína ligadora de colágeno \\
\hline DNA & Ácido Desoxirribonucléico \\
\hline EBP & Proteína ligadora de elastina \\
\hline$e b p$ & Gene codificador da proteína ligadora de elastina \\
\hline EDTA & Ácido Etileno-Diamino Tetra-Acético \\
\hline ENO & Proteína ligadora de laminina \\
\hline eno & Gene codificador da proteína ligadora de laminina \\
\hline ETA & Toxina Esfoliativa A \\
\hline eta & Gene codificador da Toxina Esfoliativa A \\
\hline ETB & Toxina Esfoliativa B \\
\hline
\end{tabular}


$e t b$

FIB

fib

FNBA

fib

FNBA

fnbA

FNBB

$f n b B$

HLA

hla

HLB

hlb

HLG

hlg

ICAA

icaA

ICAD

icaD

$\mathrm{KDa}$

LUKDE

lukED

MHC

MRSA

MSSA

ORF's

ORSA

$\mathrm{pb}$

PBP

PCR

PFGE
Gene codificador da Toxina Esfoliativa B

Proteína ligadora de fibrinigênio

Gene codificador da proteína ligadora de fibrinigênio

Proteína A ligadora de fibronectina

Gene codificador da proteína ligadora de fibrinigênio

Proteína A ligadora de fibronectina

Gene codificador da proteína A ligadora de fibrinigênio

Proteína B ligadora de fibronectina

Gene codificador da proteína B ligadora de fibrinigênio

Hemolisina A ou Alfa-toxina

Gene codificador da Hemolisina A

Hemolisina B ou Beta-hemolisina

Gene codificador da Beta-Hemolisina

Hemolisina Gama

Gene codificador da Gama-Hemolisina

Proteína A de adesão intercelular

Gene codificador da proteína A de adesão intercelular

Proteína D de adesão intercelular

Gene codificador da proteína D de adesão intercelular

Kilodalton

Leucocidina LukED

Gene codificador da Leucocidina LukED

Complexo Principal de Histocompatibilidade

Staphylococcus aureus Resistente à Meticilina

Staphylococcus aureus Sensível à Meticilina

Open Reading Frames

Staphylococcus aureus Resistente à Oxacilina

Pares de Base

Proteína Ligadora de Penicilina

Reação em Cadeia da Polimerase

Eletroforese em Gel por Campo Pulsado 
PTs

PTSAgs

PVL

SAGs

SAPIs

SEA-SEE

sea-see

SSSS

TCR

TSST-1

tst

UFC

RNA

SCCmec

Tris
Toxinas Pirogênicas

Toxinas Pirogênicas com Atividade de Superantígenos

Leucocidina Panton-Valentine

Superantígenos

Ilhas de Patogenicidade

Enterotoxinas A-E

Genes codificadores das Enterotoxinas A-E

Síndrome da Pele Escaldada Estafilocócica

Receptor de Células T

Toxina da Síndrome do Choque Tóxico

Gene codificador da Toxina da Síndrome do Choque Tóxico

Unidades Formadoras de Colônias

Ácido Ribonucléico

Cassete Cromossômico Estafilocócico mec

Tris-hidroximetilaminometano (2-amino-2-(hidroximetil) propano-1, 3-diol) 


\section{SUMÁRIO}

1.

1.1

1.1.1

1.1 .2

1.1.3

1.1.4

1.2

1.2.1

1.3

1.3.1

1.3.2

1.3.3

1.4

1.5

1.6

1.7

1.7.1

1.7.1.1

1.7.1.2

1.7.1.3

1.7.1.4

1.7.2

1.7.2.1

1.7.2.2

1.7.2.3

2.

3.

3.1

3.2

3.2 .1

3.2.2

3.2 .3

3.2 .4

3.2 .5

3.2.6

3.2 .7

3.2 .8

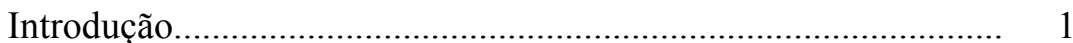

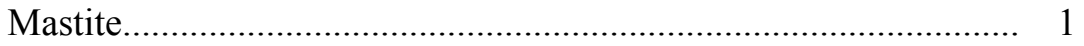

Mastite clínica e subclínica........................................................... 1

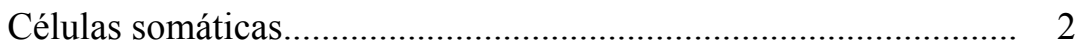

Mastite em bovinos leiteiros.......................................................... 2

Mastite em ovinos leiteiros.......................................................... 3

Colonização da glândula mamária e estabelecimento da mastite

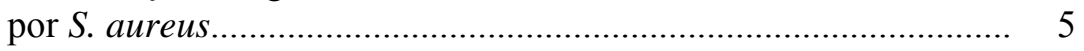

Imunidade da glândula mamária..................................................... 6

Estafilococos coagulase positivos................................................. 7

Staphylococcus aureus............................................................... 8

Staphylococcus aureus resistentes à oxacilina (ORSA)........ 9

Borderline oxacillin-resistant Staphylococcus aureus (BORSA) .............................................................. 10

Locus agr e a regulação da expressão dos genes de virulência................................................................... 13

Adesinas................................................................... 14

Genes relacionados à produção de biofilme......................... 18

Toxinas estafilocócicas................................................ 20

Citotoxinas............................................................... 21

Alfa-toxina.............................................................. 21

Beta-hemolisina...................................................... 22

Delta-hemolisina................................................... 24

Leucotoxinas bi-componentes........................................... 25

Toxinas com atividade de superantígenos.......................... 29

Enterotoxinas Estafilocócicas (SEs)................................... 30

Toxina da Síndrome do Choque Tóxico (TSST-1)............... 33

Toxinas Esfoliativas (ETs)................................................ 34

Objetivos..................................................................... 36

Material e métodos......................................................... 37

Amostras bacterianas.................................................... 37

Metodologia................................................................. 37

Identificação fenotípica das amostras de estafilococos coagulase positivos......................................................... 37

Extração do DNA cromossômico.......................................... 38

Confirmação genotípica da espécie por meio da detecção do gene $n$ ис...................................................................... 39

Eletroforese em gel de agarose........................................... 40

Determinação das linhagens de $S$. aureus e demais espécies coagulase positivas por meio de eletroforese em campo pulsado (PFGE) ......................................................... 40

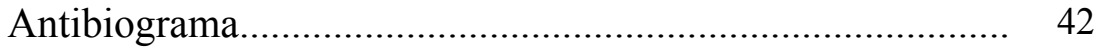

Confirmação da resistência à oxacilina................................. 42

Determinação da concentração inibitória mínima (CIM) de oxacilina. 

das estruturas gênicas relativas a fatores de virulência (toxinas).

Reação em cadeia da polimerase (PCR) para amplificação dos genes de adesinas e dos genes relacionados à produção de biofilme.

Reação em cadeia da polimerase (PCR) para tipagem do sistema agr.

4.

Identificação fenotípica das cepas de estafilococos coagulase positivos.

Confirmação genotípica da espécie por meio da detecção do gene nuc......

Determinação das linhagens de $S$. aureus e demais coagulase positivos por meio de eletroforese em campo pulsado (PFGE).

Amostras bovinas provenientes das fazendas do Município de Nova Odessa - SP.

Amostras ovinas provenientes da região do agreste do Município de Garanhuns - PE

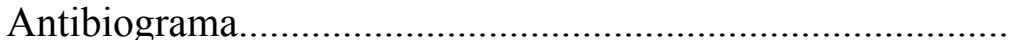

Determinação da concentração inibitória mínima (CIM) de oxacilina.

Fatores de virulência, grupo agr e os perfis clonais (PFGE) de $S$. aureus e outras espécies coagulase positivas provenientes de leite e óstios bovinos e de

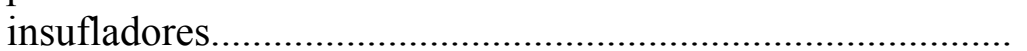

Genes relacionados à adesão e formação de biofilme............ 56

Genes codificadores de citotoxinas e toxinas com atividade de superantígenos.

Fatores de virulência e os perfis clonais (PFGE) dos demais estafilococos coagulase positivos provenientes de bovinos... Fatores de virulência, grupo agr e os perfis clonais (PFGE) de $S$. aureus provenientes de ovinos.

Genes codificadores de citotoxinas e toxinas com atividade de superantígenos

Discussão. 


\section{Lista de figuras}

Figura 1 Perfis de restrição (PFGE) do DNA das cepas resistentes à oxacilina com utilização da enzima de restrição SMAI.......

Figura 2 Perfis de restrição (PFGE) do DNA das cepas provenientes de amostras de leite mastítico bovino das fazendas A e B com utilização da enzima de restrição SMAI.......................

Figura 3 Perfis de restrição (PFGE) do DNA das cepas provenientes de amostras de leite mastítico bovino da fazenda $\mathrm{C}$ com utilização da enzima de restrição SMAI..............................

Figura 4 Dendrograma das cepas coagulase positivas provenientes de bovinos e insufladores - SP...........................................

Figura 5 Dendrograma das cepas $S$. aureus provenientes de ovinos

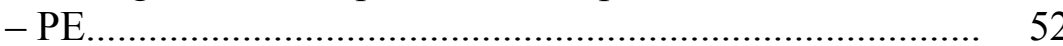

Figura 6 Valores de concentração inibitória mínima (CIM) de oxacilina apresentados pelas cepas BORSA...................... 54 


\section{Lista de tabelas}

Tabela 1 Iniciadores para amplificação dos genes nuc.....................

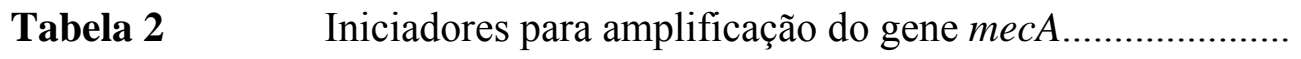

Tabela 3 Iniciadores para amplificação dos genes codificadores de

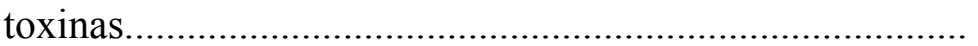

Tabela 4 Iniciadores para amplificação dos genes codificadores de adesinas e biofilmes................................................ 46

Tabela $5 \quad$ Iniciadores para tipagem do sistema regulatório agr..........

Tabela 6 Perfis de susceptibilidade dos isolados provenientes de bovinos e ovinos...............................................................

Tabela 7 Distribuição dos perfis de susceptibilidade dos isolados provenientes de leite e óstios bovinos e de insufladores das fazendas do município de Nova Odessa - SP..............

Tabela 8 Distribuição dos genes codificadores dos fatores de virulência e grupo agr entre os perfis clonais (PFGE) de $S$. aureus e outras espécies coagulase positivas provenientes de leite e óstios bovinos e de insufladores.... 55

Tabela 9 Distribuição dos genes codificadores dos fatores de virulência e grupo agr entre os perfis clonais (PFGE) de $S$. aureus provenientes de ovinos. 


\section{RESUMO}

A mastite é um sério problema em rebanhos leiteiros com consideráveis conseqüências econômicas. Embora alguns patógenos possam causar essa doença, Staphylococcus aureus é o mais importante agente etiológico em mastites bovinas e ovinas. $\mathrm{O}$ surgimento de linhagens resistentes a diferentes antibióticos e a presença de múltiplos fatores de virulência dificultam o tratamento das infecções causadas por essa espécie. Neste estudo, foram analisados 70 isolados de estafilococos coagulase positivos de origem animal: 52 provenientes de amostras de leite de bovinos portadores de mastite subclínica, do óstio dos tetos desses animais e de insufladores de três fazendas de exploração leiteira do Estado de São Paulo. Os outros 18 isolados foram provenientes de ovinos da região do agreste do Estado de PE, sendo 6 de casos de mastite clínica e 12 de casos de mastite subclínica. Por meio da eletroforese de campo pulsado (PFGE), pôde-se concluir que houve alta diversidade genética entre as linhagens de $S$. aureus isoladas das diferentes fontes analisadas das três fazendas do Estado de SP. No entanto, um perfil clonal comum foi identificado nas amostras de leite de duas dessas fazendas e, em uma terceira fazenda, houve a predominância de outro perfil clonal de $S$. aureus entre os isolados de leite bovino proveniente de animais portadores de mastite subclínica. Em relação às outras espécies coagulase positivas, todas originadas de óstios bovinos, foi possível determinar os perfis clonais dos isolados S. schleiferi spp coagulans e $S$. delphini e identificar a ocorrência de dois perfis distintos entre as linhagens de $S$. intermedius. Os isolados $S$. aureus provenientes de ovinos mostraram baixa diversidade genética com três perfis clonais comuns aos casos de mastite clínica e subclínica. Observou-se, em relação à combinação dos fatores de virulência de bovinos e ovinos, a ocorrência do gene cflA em $100 \%$ das amostras, o que indica o seu envolvimento no processo de colonização da glândula mamária, independente do hospedeiro. Dois clones bovinos destacaram-se por apresentar multiplicidade dos genes codificadores dos fatores de virulência. No entanto, houve pouca ocorrência dos genes relacionados ao processo toxigênico entre os isolados dessa espécie animal, ao contrário das cepas provenientes de ovinos. Em relação ao sistema regulador agr, o grupo II foi associado aos perfis clonais que apresentaram maior combinação dos genes codificadores dos fatores de virulência em isolados $S$. aureus provenientes de bovinos. Já o grupo III e agr negativos, aos isolados portadores de poucos desses genes. A presença do gene eta, pouco freqüente em linhagens animais, foi associada tanto com cepas bovinas agr negativas como do grupo II. Assim como nos isolados bovinos, o grupo II de $a g r$, em ovinos, também foi relacionado com o perfil que apresentou maior combinação dos fatores de virulência, incluindo a associação dos genes sec e tst, mas também com perfis portadores de poucos genes de adesinas ou de nenhum gene para exotoxinas. O mesmo foi observado para o grupo I em linhagens ovinas. As cepas resistentes à oxacilina (BORSA), provenientes de isolados bovinos e de insufladores, apresentaram concentração inibitória mínima $\geq 1-\leq 16 \mu \mathrm{g} / \mathrm{ml}$ com múltipla resistência a outros antimicrobianos, mas foram negativas para o gene mecA, o que indica que sejam portadoras de outros mecanismos de resistência aos beta-lactâmicos, diferente da produção de PBP2a.

Palavras-chave: Mastite. Staphylococcus aureus. Virulência. Resistência. 


\begin{abstract}
Mastitis is a serious problem in dairy herds with considerable economic consequences. Although some pathogens may cause this disease, Staphylococcus aureus is the most important etiologic agent in bovine and ovine mastitis. The appearance of antibiotic resistant strains and the presence of multiple factors of virulence, make the treatment of the infections caused by these species very difficult. In this study, we analyzed 70 isolates of coagulase positive Staphylococcus sp of animal origin: 52 from milk samples of subclinic mastitis, bovine teats and milking linners collected in three dairy farms from São Paulo State. The other 18 isolates were from the agreste region ovine in the State of Pernanbuco, with 6 strains from cases of clinic mastitis and 12 cases of subclinic mastitis. By pulsed-field electrophoresis (PFGE), we found high genetic diversity among $S$. aureus strains from different sources analyzed in the three farms from São Paulo State. However, a common S. aureus cloning profile was identified in the milk samples from two farms and, the third farm, presented a predominance of different profile from two previous farms. The six coagulase positive isolates from bovine teats were identified as $S$. schleiferi spp coagulans (1), S. delphini (1) and $S$. intermedius (4). This last specie presented two distinct profiles among strains. The ovine $S$. aureus strains showed a low genetic diversity presenting three common profiles in both clinic and subclinic mastitis. The cflA gene occurred in $100 \%$ of the bovine and ovine strains, showing its involvement in the process of colonization of the mammary glands independent of host species. Two bovine clones was notable for presenting multiplicity of virulence factors genes. However, there was a low occurrence of toxin encoding genes among bovine strains, unlike the ovine strains. The group II agr regulatory systems of $S$. aureus from bovine strains was associated to a wider combination of the virulent factors encoding genes. However, group III and negative agr was associated to few combination genes. Although the gene eta is, in general, less frequent in animal strains, in this study it was associated in both agr negative and group II agr bovine strains. In ovine, agr group II, as in the bovine isolates, it was also related to a wider combination of virulence factors, including the association of sec and tst genes. It was also found a few genes encoding adhesion and exotoxins in this group, occurring the same in agr group I in ovine strains. The borderline oxacillin-resistant Staphylococcus aureus (BORSA) strains isolated from bovine ostium, milk and milking apparatus line presented minimum inhibitory concentration $\geq 1-\leq 16 \mu \mathrm{g} / \mathrm{ml}$ with multiple resistance to other antimicrobial, but they were negative to the mecA gene, suggesting they are carrying other resistance mechanisms to beta-lactam antibiotics, different from the production of PBP2a.
\end{abstract}

Keywords: Mastitis. Staphylococcus aureus. Virulence. Resistance. 


\section{Introdução}

\subsection{Mastite}

A mastite é o processo inflamatório da glândula mamária que afeta a produção leiteira tanto em qualidade como em quantidade resultando em alterações físicas, químicas e bacteriológicas do leite, assim como em alterações patológicas no tecido glandular (BLOOD \& RADOSTITS, 1991). Essa doença é a principal afecção dos animais destinados à produção leiteira pela sua alta freqüência, pelos aspectos econômicos a ela relacionados diminuição da produção e menor rendimento dos subprodutos lácteos para a indústria de laticínios - e pelos aspectos de Saúde Pública, pois o leite pode veicular uma série de microrganismos capazes de ocasionar infecções e toxinfecções alimentares (LANGONI, 2007).

A mastite pode ter diversas causas: traumática, infecciosa, metabólica, fisiológica e alérgica. Entre essas, a infecciosa é considerada a mais importante por não ser autolimitante e por ser contagiosa, podendo disseminar-se rapidamente a outros animais do rebanho e, dessa forma, adquirir importância para a Saúde Pública pela possibilidade de veiculação de microrganismos causadores de mastite, toxinas e resíduos de antimicrobianos no leite (COSTA, 1998).

\subsubsection{Mastite clínica e subclínica}

De acordo com a intensidade do processo inflamatório, as mastites são classificadas em clínica e subclínica. A mastite clínica caracteriza-se por modificações visíveis no leite, como a presença de grumos de fibrina ou pus e, muitas vezes, alterações na glândula mamária como aumento de volume, presença de dor, aumento de temperatura e rubor. A mastite subclínica, ao contrário, não apresenta sintomas clínicos evidentes, tendo o leite aspecto macroscópico normal sem sinais visíveis de inflamação do úbere (BLOOD \& RADOSTITS, 1991). 


\subsubsection{Células somáticas}

As células somáticas são principalmente de dois tipos: células epiteliais e células brancas, de origem sanguínea. As células epiteliais existem normalmente no leite e são predominantes em glândulas mamárias não infectadas. Elas não têm papel imunológico, mas podem liberar substâncias chamadas citoquinas que atraem células brancas. As células brancas predominantes em uma glândula normal são os macrófagos e, na glândula infectada, neutrófilos e células T. Em mastites agudas, os neutrófilos podem representar praticamente $100 \%$ das células encontradas na secreção mamária. Em casos crônicos o quadro é diferente, com as células T apresentando maior participação. As células epiteliais

já estão presentes na glândula mamária e seu aparecimento é conseqüência do processo natural de desprendimento de células velhas. As demais têm origem sanguínea e são atraídas para o interior da glândula mamária por meio da inflamação produzida por uma infecção. O processo inflamatório produz substâncias que são quimiotáticas para os neutrófilos. Essas substâncias se ligam ao endotélio vascular nos locais próximos à infecção fazendo com que os neutrófilos que apresentam receptores para elas em suas membranas deslizem sobre a parede interna do vaso sanguíneo atravessando o endotélio transferindo-se para o leite (VAZ, 2007).

Para o diagnóstico das mastites clínicas, além de exames minuciosos da glândula mamária, utiliza-se a caneca de fundo negro ou prova de Tamis para a observação dos primeiros jatos de leite quanto à presença de grumos, coágulos de pus, sangue ou leite aguado. Já para os casos de mastite subclínica, o diagnóstico pode ser realizado a partir de métodos indiretos como a contagem das células somáticas (CCS) e o California Mastitis Test (CMT) (LANGONI, 2007).

\subsubsection{Mastite em bovinos leiteiros}

Os processos inflamatórios da glândula mamária são freqüentes e adquirem importância em bovinos por causarem grandes prejuízos à pecuária leiteira em virtude da redução da produção de leite, gastos com medicamentos e com assistência veterinária, descarte de leite contaminado após tratamento e descarte precoce de animais doentes (COSTA et al., 1999). O controle da mastite infecciosa bovina baseia-se em medidas 
preventivas, tratamento imediato dos casos clínicos e , nos casos subclínicos, tratamento no período seco (COSTA et al., 1994).

É comum a prevalência de Staphylococcus aureus em mastites bovinas. As infecções causadas por esse patógeno persistem por um longo tempo, de modo que as glândulas mamárias infectadas atuam como reservatórios a partir dos quais o microrganismo pode distribuir-se a outros bovinos dentro do rebanho e, ocasionalmente, a outros rebanhos (BRAMLEY \& DODD, 1984). É de amplo conhecimento que a transmissão de S. aureus ocorre principalmente durante a ordenha com vacas cronicamente infectadas que atuam como os principais reservatórios desse processo (ROBERSON et al., 1994) e, mesmo quando medidas de controle são implementadas, novas infecções intramamárias causadas por esse microrganismo continuam a ocorrer, impossibilitando sua erradicação (ZADOKS et al., 2002). Embora as linhas de ordenha mecânica sejam importantes fontes nesse processo de transmissão de S. aureus em rebanhos leiteiros - uma vez que esses equipamentos podem estar contaminados com a bactéria proveniente da pele do teto ou do leite (SANTOS et al., 2003; FOX et al., 1991) - existem, ainda, outras fontes de S. aureus como a ração, a pele bovina e outros animais (ROBERSON et al., 1994).

\subsubsection{Mastite em ovinos leiteiros}

A mastite dos pequenos ruminantes tem como origem predominante as infecções bacterianas. As ovelhas apresentam com maior freqüência que fêmeas de outras espécies o quadro mais grave de mastite, a mastite flegmonosa, cuja evolução tende à gangrena e, portanto, é descrita por muitos autores como mastite gangrenosa (SMITH, 1994; ANDERSON et al., 2005), podendo se manifestar de forma aguda e subaguda. Staphylococcus aureus é um agente comum desse tipo de mastite, podendo o mesmo hospedeiro apresentar quadros distintos frente ao patógeno e responder de maneira diferente em cada glândula mamária (LIBERA et al., 2007). No entanto, essa independência entre as mamas, quando infectadas pelo mesmo agente, torna-se relativa (SANTOS et al., 2007). Foi observado nesse estudo de indução experimental de mastite em ovinos que a mama contralateral à inoculação, a mama controle, também diminuiu a produção de leite apresentando alterações em sua composição. 
Os animais acometidos pela mastite gangrenosa aguda apresentam inicialmente um quadro sistêmico com febre seguida de hipotermia, inapetência, desidratação, congestão da mucosa ocular, taquicardia, taquipnéia, hipomotilidade à atonia ruminal, fezes diarréicas, perda de peso e até morte do animal. No início, a pele da glândula mamária se apresenta eritematosa, com aumento de temperatura e o edema pode ser local ou mesmo atingir a região abdominal ou xifóidea para, posteriormente, tornar-se cianótica (MENZIES \& RAMANOON, 2001; ANDERSON et al., 2005). A patogenia da afecção em ovinos pode levar à perda da mama e até mesmo à morte do animal (RADOSTITIS et al, 2002; PUGH, 2005).

CONTRERAS et al (2007), em um trabalho de revisão, descreveram a freqüência dos agentes causadores de mastite em pequenos ruminantes e destacaram Staphylococcus spp como mais freqüente. Mesmo sendo mais comum a presença de estafilococos coagulase negativos, é preocupante a ocorrência de S. aureus, pois esse microrganismo pode causar mastite gangrenosa devido à produção de toxinas específicas responsáveis por lesões graves na mama, como a alfa-toxina que produz necrose nos alvéolos (SANTOS et al., 2007). S. aureus é bastante comum na pele e nas mucosas de ovelhas, sendo as infecções relacionadas a esta bactéria, muitas vezes, atribuídas à falta de higiene durante a ordenha, à sucção excessiva do cordeiro ou ao contato com pastagens contaminadas (ANDERSON et al., 2005). As toxinas de S. aureus podem provocar trombose vascular, gangrena e desprendimento de tecidos subjacentes. Geralmente, a infecção causa um processo inflamatório local que altera o fluxo sanguíneo mamário gerando uma diminuição da produção de leite e alterações na coloração do úbere decorrentes da isquemia. (SMITH, 1994; ANDERSON et al., 2005). Outro fator que contribui com a invasão bacteriana e inibição da resposta imune do hospedeiro é a grande variedade na produção de hemolisinas por S. aureus (SILVA et al., 2005).

Há prejuízos qualitativos e quantitativos à produção de leite com conseqüências tanto para animais especializados para esta função, quanto para os não especializados (CLEMENTS et al., 2003; BLAGITZ, 2007). Como conseqüência da presença de $S$. aureus, o leite consumido pelo homem pode apresentar toxinas e/ou a própria bactéria com potencial zoonótico (CONTRERAS et al, 2007). 


\subsection{Colonização da glândula mamária e estabelecimento da mastite por S. aureus}

A aderência de $S$. aureus ao canal do teto do úbere é considerada a primeira etapa da infecção da glândula mamária (SUTRA \& POUTREL, 1994). No período entre ordenhas, esse canal encontra-se normalmente fechado por um anel muscular bloqueado por um tampão de queratina derivada das células da parede do próprio canal. Essa queratina é encontrada tanto na cisterna do teto como no ducto papilar tendo a função de vedação deste. A ação da queratina apresenta um efeito relativo conforme o lipídio associado a essa proteína. Estudos eletroforéticos mostraram que frações que migraram para o anodo tinham maior capacidade de destruir colônias de S. aureus, enquanto frações catódicas foram apenas bacteriostáticas (SENFT et al., 1990).

A ordenha ou o ato de mamar remove o tampão de queratina tornando flácido o esfíncter e mais vulnerável a infecções o canal do teto. Após o término da ordenha, a musculatura retoma seu tônus e o tampão é novamente formado. No entanto, alguns fatores podem impedir este retorno à normalidade: seqüência de ordenhas realizadas com ordenhadeira com excesso de vácuo ou com pulsação excessivamente rápida, produtos químicos como desinfetantes com ação cáustica, baixa temperatura, dentre outros. Consequentemente, podem provocar uma hiperqueratose na extremidade do canal do teto, o que dificulta o seu fechamento. Esta lesão caracteriza-se por um anel esbranquiçado e ligeiramente elevado ao redor do orifício, podendo haver necrose da abertura, com rachaduras que se irradiam do ponto inicial do tecido necrosado e que podem servir de abrigo para os agentes patogênicos (VAZ, 2007).

Por outro lado, S. aureus tem a capacidade de produzir um amplo número de fatores de virulência (FITZGERALD et al., 2000). Alguns podem ser mais importantes que outros no desenvolvimento de diferentes doenças ou em diferentes estágios da patogênese de determinadas infecções (KALOREY et al., 2007). Esse patógeno pode apresentar adesinas específicas que se ligam a uma diversidade de proteínas hospedeiras, principalmente na matriz extracelular do hospedeiro, como colágeno, fibrinogênio e fibronectina (NOVICK et al., 2000). A interação com os tecidos do hospedeiro representa um papel crítico no estabelecimento da infecção da mastite por S. aureus (KERRO DEGO et al., 2002). 


\subsubsection{Imunidade da glândula mamária}

Uma vez que o agente patogênico atravessa o canal do teto e alcança a cisterna mamária, passam a atuar, especialmente, os fatores solúveis e as células fagocíticas da imunidade inespecífica. A enzima lactoperoxidase, um dos fatores solúveis, é uma substância que ajuda na prevenção e controle de infecções mastíticas, mas, ao contrário de seu efeito bactericida em Gram-negativos, é bacteriostática para Gram-positivos (KUMAR \& BHATIA, 1994).

O complemento é considerado um fator quimiotático para o recrutamento de células fagocíticas para o local da infecção. No entanto, um de seus componentes, o C5a, é pouco estimulado por Staphylococcus sp e o C3, apesar de ser eficiente em opsonizar isolados de S. aureus de casos de mastites bovinas, não promove alterações significativas na fagocitose das bactérias, o que sugere que sua ligação com componentes de superfície de $S$. aureus não contribui para a defesa da glândula mamária bovina (KEHRLI, 2001 citado por CARVALHO, 2005).

Com relação às citocinas IL-8 e TNF- $\alpha$, ao contrário do que ocorre em E. coli, sua produção não é observada em infecções causadas por S. aureus, o que explica em parte a maior capacidade dessa espécie em estabelecer infecções crônicas (BANNERMAN et al., 2004). Já IL-2 e G-CSF são importantes para o controle de infecções causadas por $S$. aureus, pois em bovinos aumentam o número de linfócitos e a produção de anticorpos (NICKERSON, 1991). Citocinas da família dos fatores estimulantes de colônias (CSF) atuam na regulação positiva da resposta imune, aumentando em quantidade e qualidade os leucócitos recrutados para o sítio inflamatório, mas, apesar da contagem de células somáticas (CCS) de bovinos tratados com G-CSF ter aumentado no estudo de SORDILLO \& DALEY (1995), não foi observada nenhuma relação entre esse aumento com as unidades formadoras de colônia de S. aureus.

Um recente estudo (BOYSO et al., 2008) mostrou que o tratamento de células endoteliais bovinas com TNF- $\alpha$ ou IL-1 $\beta$ aumentou a capacidade dessas células para

eliminar tanto S. aureus como S. epidermidis, sendo este patógeno oportunista mais sensível ao mecanismo de eliminação das células endoteliais, enquanto aquele foi capaz de se multiplicar no citoplasma dessas células. Observou-se, também, que linhagens 
citotóxicas de $S$. aureus escaparam da atuação dos lisossomos, ao contrário de linhagens não citotóxicas, eliminadas por vias de degradação lisossomal.

Outro fator solúvel importante é a lactoferrina. Um aumento na produção dessa substância pelas células epiteliais glandulares é relacionado com a exposição dessas células a E. coli e S. aureus. De qualquer forma, a quantidade de lactoferrina em leite de vacas é bem inferior à encontrada em leite de búfalas, por exemplo (WELLNITZ \& KERR, 2004).

As defesas celulares inespecíficas da glândula mamária normal são representadas pelos macrófagos e células fagocíticas que, como as demais células brancas, são capazes de reconhecer estruturas bastante conservadas na superfície das bactérias dentro de uma classe de patógenos. No entanto, a resposta celular na glândula mamária é muito inferior em eficácia em relação à resposta observada, por exemplo, no sangue ou nos demais tecidos do organismo. Vários fatores parecem contribuir para isto, mas o mais aceito é que no leite as células esgotam sua capacidade fagocítica ao englobarem micelas de caseína e glóbulos de gordura (VAZ, 2007).

Em relação à imunidade específica, sabe-se que, na glândula mamária, a quantidade de células produtoras de anticorpos é reduzida. As imunoglobulinas presentes no leite são do tipo IgG1, IgG2, IgA e IgM, esta última em reduzidas concentrações. Em bovinos, Staphylococcus aureus induz uma resposta intensa de IgG1 e IgA durante toda a lactação (BUTLER, 1999). Embora a concentração de IgG1 seja alta tanto no sangue como no leite, em ruminantes, essa imunoglobulina não é a mais eficaz, pois, como $\operatorname{IgA}$, não atua como opsonina em função dos neutrófilos desses animais não possuírem receptores específicos, o que dificulta a opsonização dos antígenos bacterianos. Os receptores presentes nos neutrófilos de ruminantes são específicos para $\operatorname{IgG} 2$, que normalmente ocorre em baixas concentrações (VAZ, 2007).

\subsection{Estafilococos coagulase positivos}

O gênero Staphylococcus compreende diversas espécies e subespécies que se encontram amplamente distribuídas na natureza, sendo principalmente encontrados na pele, membranas e mucosas de aves e mamíferos (KLOOS \& BANNERMAN, 1999). O gênero Staphylococcus foi proposto em 1884 por Rosenbach e inserido dentro da família 
Micrococaceae. Recentemente, estudos de biologia molecular, perfis de ácidos graxos, composição da parede celular e, principalmente, estudos com RNA ribossômico 16S promoveram a inclusão do gênero Staphylococcus em uma nova família, a Staphylococaceae (GARRITY, 2006). Atualmente, já são 41 espécies descritas dentro do gênero (BANNERMAN, 2003; EUZÉBY, 2007), sendo a maioria negativa para a presença da coagulase. A síntese dessa enzima - propriedade que caracteriza e identifica as outras espécies do gênero - é restrita ao $S$. aureus, S. schleiferi subsps. coagulans, S. intermedius, S. hyicus e S. delphini (BANNERMAN, 2003).

Em amostras clínicas humanas, a detecção da coagulase é suficiente para a identificação e distinção de $S$. aureus dos estafilococos coagulase negativos. No entanto, esse procedimento fenotípico não diferencia $S$. aureus das outras espécies coagulase positivas do gênero. Para amostras veterinárias, essa distinção é importante para evitar falsas identificações de $S$. aureus, uma vez que $S$. intermedius e $S$. hyicus, também coagulase positivos, são freqüentemente isolados de várias espécies animais.

Os estafilococos são cocos Gram-positivos, imóveis, anaeróbios facultativos, apresentando metabolismo fermentativo com produção de ácido e não gás, não fotossintéticos, não esporulados, catalase positivos e capazes de crescer em meios contendo $10 \%$ de cloreto de sódio. São microrganismos mesófilos, com temperatura de desenvolvimento de 7 a $48^{\circ} \mathrm{C}$ com ótima de $37^{\circ} \mathrm{C}$ e $\mathrm{pH}$ na faixa de 4 a 10, com ótimo de 6 a 7 (KLOOS \& BANNERMAN, 1999).

\subsubsection{Staphylococcus aureus}

S. aureus pode causar uma gama de infecções em gado e é o mais comum agente etiológico de mastite bovina contagiosa, causando significativas perdas na indústria leiteira (SEARS \& MCCARTHY, 2003). É também o microrganismo patogênico mais freqüentemente isolado no leite cru (ZECCONI \& HAHN, 2000). Destaca-se como microrganismo causador de mastite contagiosa pela maior ocorrência nos rebanhos mundiais e de tratamento mais difícil devido à elevada resistência aos antibióticos (FAGUNDES \& OLIVEIRA, 2004). Infecções intramamárias por S. aureus geralmente respondem mal a tratamentos antimicrobianos e se tornam crônicas (SOL et al., 2000). 
S. aureus causa uma variedade de doenças em múltiplas espécies de hospedeiros incluindo humanos e animais (HERRON-OLSON et al., 2007). No entanto, estudos têm mostrado um limitado número de genótipos associados à persistência da mastite em bovinos leiteiros ressaltando a idéia de que certos genótipos de $S$. aureus são particularmente bem sucedidos como causadores dessa doença (KAPUR et al., 1995; REINOSO et al., 2004; HAVERI et al., 2005).

\subsubsection{Staphylococcus aureus resistentes à oxacilina (ORSA)}

Logo após a criação da meticilina, beta-lactâmico sintético resistente à ação das beta-lactamases, foi descrito por JEVONS (1961) o primeiro caso de resistência a esse antibiótico em S. aureus. Os estafilococos resistentes à oxacilina, antibiótico análogo à meticilina, são resistentes a todos os antibióticos beta-lactâmicos atualmente disponíveis, dificultando o tratamento contra infecções estafilocócicas (CHAMBERS, 1997).

$\mathrm{O}$ mecanismo que confere resistência à oxacilina e aos demais antibióticos betalactâmicos é caracterizado pela expressão de uma proteína ligadora de penicilina (penicillin binding protein) modificada - a PBP2'ou PBP2a - extremamente funcional, mas com afinidade reduzida por beta-lactâmicos, conferindo à bactéria a capacidade de sintetizar a parede celular mesmo na presença de meticilina. A PBP2a é codificada pelo gene mecA, carreado em um elemento genético móvel denominado cassete cromossômico estafilocócico mec ( $\mathrm{SCCmec).} \mathrm{A} \mathrm{estrutura} \mathrm{desse} \mathrm{consiste} \mathrm{em} \mathrm{dois} \mathrm{componentes} \mathrm{genéticos.}$ O primeiro é o gene mec composto pela IS431, o gene mecA e seus reguladores, um operon com um repressor (mecl) e um transdutor de sinal (mecR1), esses dois últimos, elementos regulatórios transcritos de forma divergente. Os genes $c c r$, responsáveis pela transposição do SCCmec, são o segundo componente desse elemento genético móvel. (ITO et al., 2003).

Recentemente, a transmissão de uma linhagem MRSA entre vacas e humanos, a CC1, previamente descrita nesses, foi relatada por JUHÁSZ-KASZANYITZKY et al (2007). Outros três casos envolvendo a linhagem ST188 e oito casos envolvendo a CC97 relativamente incomuns em humanos, mas que ainda não tinham sido relatadas em animais - colocam em questão a idéia de que somente isolados animais causam doenças animais e que isolados humanos são restritos a essa espécie e apenas causam doenças humanas (SEARS \& MCCARTHY, 2003). 
Linhagens MRSA também são uma preocupação em outras espécies, como cães, cavalos e porcos, que freqüentam as fazendas leiteiras (LOEFFLER et al., 2005; WEESE et al., 2005; HUIJSDENS et al., 2006), pois esses animais podem atuar como reservatórios de isolados humanos podendo promover a evolução de linhagens resistentes e patogênicas. A disseminação de resistência entre linhagens S. aureus é facilitada pelo fato dos genes codificadores de tais mecanismos serem tipicamente codificados por elementos genéticos móveis, como os cassetes cromossômicos estafilocócicos (SCCmec), plasmídios e transposons (LINDSAY \& HOLDEN, 2006).

\subsubsection{Borderline oxacillin-resistant Staphylococcus aureus (BORSA)}

As linhagens BORSA são caracterizadas por apresentarem uma concentração inibitória mínima (CIM) de oxacilina próxima ao breakpoint de resistência (CLSI, 2007). São isolados mecA negativos e apresentam baixo nível de resistência à oxacilina com CIMs entre 1-8 $\mu \mathrm{g} / \mathrm{ml}$ (BARG et al., 1991). Essa redução de susceptibilidade pode resultar de mecanismos intrínsecos relacionados à capacidade de ligação alterada das proteínas ligadoras de penicilinas ou de mecanismos extrínsecos que dependem da atividade das betalactamases (MASSIDDA et al., 2006).

A natureza não intrínseca dessa redução de sensibilidade foi confirmada pela inabilidade de detectar a PBP2a em linhagens BORSA por ensaios convencionais de PBP (MONTANARI et al., 1990) ou por hibridização com sondas específicas para o gene mecA que codifica a PBP2a (CHAMBERS et al, 1989; KNAPP et al, 1996). Segundo a descrição inicial de MCDOUGAL \& THORNSBERRY (1986), essas linhagens produzem grandes quantidades de beta-lactamases e são completamente sensíveis às penicilinas resistentes às penicinilases (PRPs) na presença de inibidores de beta-lactamases. Não são heteroresistentes e nem apresentam múltipla resistência. Segundo esses autores, as betalactamases, quando produzidas em excesso, apresentam uma atividade parcial de hidrólise da meticilina e PRPs relacionadas.

Outra explicação foi proposta por MASSIDDA et al (1992; 1996). Em adição às clássicas penicinilases, uma beta-lactamase seria capaz de hidrolizar lentamente as PRPs e outros substratos não afetados pelas penicinilases. Essa atividade de meticilinase foi 
demonstrada primeiramente por esses autores e, posteriormente, por GAL, Z. et al (2001) por espectrofotometria. De qualquer forma, o suposto gene codificador dessa enzima ainda não foi identificado. A atividade enzimática dessa beta-lactamase - ligada à membrana que hidrolisa a meticilina e a oxacilina eficientemente - não é causada pela penicinilase codificada pelo gene blaZ, uma vez que a clonagem desse gene de uma linhagem borderline em um vetor e sua transferência para uma linhagem de E. coli não tornou esse hospedeiro capaz de hidrolisar penicilinas resistentes às penicinilases (MASSIDDA et al., 1994). Isolados Borderline Oxacillin-Resistant Staphylococcus aureus (BORSA) são hiperprodutores de beta-lactamases, pertencem quase que exclusivamente ao grupo fágico $\mathrm{V}$ do complexo 94/96 e possuem um plasmídio que codifica uma penicinilase estafilocócica do tipo A, resultando em excesso de produção de beta-lactamase (MASSIDDA et al., 1996; CHAMBERS et al., 1997).

O plasmídio, denominado originalmente de $\mathrm{pBW} 15$, foi descrito por conter quatro fragmentos HindIII (de 7.0, 5.3, 3.5 e $1.4 \mathrm{~kb}$ ) com um tamanho total estimado em $17.2 \mathrm{~kb}$. Experimentos de hibridização mostraram que o gene blaZ estava contido no maior desses quatro fragmentos e uma transferência desse plasmídio para linhagens $S$. aureus sensíveis conferiu resistência à penicilina (BARG \& MCMURRAY, 1990; MASSIDDA et al., 1994). Em outro estudo (MASSIDDA et al., 2006), o pBORa53, um plasmídio parecido com o pBW15 derivado de uma linhagem BORSA já estudada, foi caracterizado e seqüenciado e revelou a presença do complexo do gene bla - constituído por blaZ, blaR1 e blaI - e de dois determinantes de resistência ao cádmio, cadD e cadX, codificadores de um novo tipo de resistência a esse elemento químico. O plasmídio pBORa53, de tamanho $17,334 \mathrm{pb}$, contém 14 ORFs e uma cópia completa do transposon Tn552, o qual compreende os três genes do complexo bla. Entre as outras 11 ORFs identificadas estão os dois determinantes de resistência ao cádmio.

Plasmídios como o pBW15 pertencem a um grupo de elementos genéticos que carregam determinantes de resistência a metais pesados como o cádmio, mercúrio e arsênio e um transposon Tn552 ou derivados desse, que codificam penicinilases. A caracterização do pBORa53 indica que plasmídios do grupo pBW15 têm uma estreita relação com linhagens BORSA, pois diferem de todos os outros plasmídios relacionados à produção de beta-lactamases. O seqüenciamento do indutor BlaR1 de pBORa53 mostrou 99\% de 
identidade com seu correspondente homólogo do Tn552 (ROWLAND \& DYKE, 1990), no entanto, ainda não foi esclarecido se as substituições encontradas em BlaR1 afetam a produção de beta-lactamase.

Com a intenção de melhor caracterizar linhagens BORSAs já descritas como produtoras de beta-lactamase e comparar sua produção de meticilinase com outras linhagens não borderline, KESERU et al. (2005) encontraram duas enzimas de pesos moleculares 30 e $13 \mathrm{kDa}$, ambas presentes em frações de membranas de linhagens BORSA e MRSA. A enzima de $30 \mathrm{kDa}$ parecia ser a responsável pela hidrólise da oxacilina, pois não foi encontrada nas membranas das linhagens sensíveis à meticilina. Essas linhagens também não produziram nenhuma beta-lactamase extracelular, ao contrário das linhagens BORSA e MRSA que secretaram uma enzima com peso molecular correspondente à enzima de $30 \mathrm{kDa}$ ligada à membrana. Além disso, quando linhagens BORSAs foram cultivadas na presença de $50 \mu \mathrm{g} / \mathrm{ml}$ de globomicina, substância que inibe o processamento das proteínas de membrana, a proteína de $30 \mathrm{kDa}$ não apareceu em eletroforese e no ensaio houve uma diminuição da atividade de hidrólise da oxacilina, o que sugere uma relação entre essa meticilinase e o fenótipo BORSA. Essa meticilinase foi produzida constitutivamente pelas linhagens BORSAs examinadas nesse estudo e sua produção pôde ser aumentada por adição de $0.5 \mu \mathrm{g} / \mathrm{ml}$ de meticilina nas culturas.

Além da nova meticilinase e da presença do plasmídio (KESERU et al., 2005 e MASSIDDA et al., 2006), outros mecanismos podem explicar o fenótipo BORSA. Foram notadas diferentes substituições na PBP2 de $S$. aureus em um estudo com a linhagem BORSA CDC-6 (HACKBARTH et al., 1995). Substituições espontâneas nessa proteína ligadora de penicilina podem ser induzidas por seleção no crescimento com ceftizoxime (LESKI \& TOMASZ, 2005).

PBP2 é uma proteína de 727 aminoácidos, essencial para a construção do peptidoglicano e que pode ser inibida por beta-lactâmicos. Apresenta um domínio Nterminal transglicosilase que compreende os aminoácidos 76-244 e um domínio C-terminal transpeptidase com os aminoácidos 360-653 (PINHO et al., 2001a, b). Substituições nesses domínios em linhagens BORSA, e não em MSSA e MRSA, poderiam explicar tal fenótipo.

Em um estudo (NADARAJAH et al., 2006), o isolado bovino MSSA RF122 (HERRON-OLSON et al; GenBank accession n $n^{0}$ NC_007622) apresentou apenas duas 
substituições na PBP2: Pro285 $\rightarrow$ Ala e Thr43 $\rightarrow$ Val. Em linhagens sensíveis como essa, as substituições foram incomuns e não promoveram resistência. Neste mesmo estudo, o gene pbp2 de linhagens que perderam o blaZ foram clonados em pRN5548 para expressão em S. aureus e observou-se que apenas esse gene é suficiente para conferir o fenótipo BORSA e que diferentes substituições na PBP2 podem promover esse fenótipo.

\subsection{Locus agr e a regulação da expressão dos genes de virulência}

Os fatores de virulência não são expressos constantemente, é vantajoso para a bactéria coordenar o que será produzido e quando. A expressão da maioria dos genes de virulência de S. aureus é controlada por um sistema de regulação global composto por dois operons divergentes, denominado agr (acessory gene regulator). A atuação do sistema agr está associada ao quorum-sensing em S. aureus, mecanismo pelo qual uma bactéria consegue "perceber" a densidade celular do meio em que se encontra. O efeito quorumsensing é conseguido pela bactéria devido a uma comunicação entre as células presentes no mesmo ambiente por meio de moléculas secretadas por uma célula e detectadas por outras, similar ao sistema endócrino em animais (MCCULLOCH, 2006).

O locus agr é composto por dois operons divergentes, controlados pelos promotores P2 e P3. O operon que tem o P2 como promotor contém quatro genes: $\operatorname{agrA}, \operatorname{agr} B, \operatorname{agrC} e$ $\arg D$. O operon com o promotor P3 contém apenas o gene da $\delta$-hemolisina (hld) e o gene para um RNA mensageiro denominado RNAIII, efetor do sistema agr. Os produtos dos genes $\operatorname{agrB}$ e $\operatorname{agrD}$, respectivamente as proteínas AgrB e AgrD, se juntam formando um peptídeo auto-indutor (AIP). AgrC é uma proteína transmembrânica com receptor para AIP. Quando AIP liga-se à AgrC, este fosforila a proteína AgrA, ativando-a. A proteína AgrA fosforilada age como indutor dos promotores P2 e P3. O produto da transcrição do operon P3 é um RNA denominado RNAIII, um mRNA que funciona como indutor ou repressor da transcrição de genes acessórios. Este mRNA nunca chega a ser traduzido a proteína, pois ele mesmo é o efetor à resposta do agr (YARWOOD \& SCHLIEVERT, 2003).

Um polimorfismo na seqüência dos genes deste sistema regulador, que correspondem ao peptídeo auto-indutor e seu receptor transmembrânico correspondente, divide as linhagens de $S$. aureus em quatro grupos alélicos específicos denominados agr I, II, III e IV, descritos por JI et al (1997). O AIP produzido por um grupo pode interferir na 
expressão do agr dos outros grupos, promovendo interferência bacteriana. O gene da $\delta$-hemolisina, hld, está contido dentro do produto transcricional RNAIII, todavia, o RNAIII logo se enovela em uma conformação não traduzível. Este RNAIII enovelado tem uma ação indutora sobre certos genes acessórios. Para que o gene da $\delta$-hemolisina seja traduzido, o RNAIII se desenovela com o auxílio de algum co-fator ainda desconhecido e então retorna à sua conformação original. O produto final da cascata do locus agr é o RNAIII. Um locus agr funcional resulta, por meio dessa molécula, em um aumento da transcrição dos genes codificadores dos fatores de virulência (YARWOOD \& SCHLIEVERT, 2003).

Os efeitos do RNAIII sobre certos genes, como os envolvidos com a adesão bacteriana, ainda não são totalmente esclarecidos. No entanto, segundo SAKOULAS et al (2002) o RNAIII inibiria a transcrição de genes que expressam proteínas envolvidas com a adesão da bactéria. Cepas com uma mutação que leva à disfunção do locus agr apresentam maior facilidade de adesão ao poliestireno e à produção de biofilme (VOUNG et al., 2000).

A expressão do sistema agr contribui com a patogênese estafilocócica em diferentes momentos da infecção. Considerando a curva de crescimento de S. aureus, observa-se com exceção da enterotoxina A que é produzida durante todas as fases de crescimento que todas as exoproteínas são secretadas na fase pós-exponencial. Por outro lado, as proteínas associadas à membrana como a proteína $\mathrm{A}$ e as adesinas são produzidas durante a fase exponencial e não na fase pós-exponencial (BOHACH et al., 1997). O locus agr tem uma atuação positiva na regulação da expressão dos genes de exoproteínas e negativa na síntese de adesinas de superfície celular durante a transição da fase exponencial para pósexponencial (CHEUNG et al., 2004).

\subsection{Adesinas}

A fibronectina - alvo para a adesina codificada pelo gene fnbA de S. aureus - é uma proteína encontrada em toda parte no hospedeiro presente em forma solúvel no sangue e na forma fibrilar nas matrizes celulares (PATTI et al., 1994). A proteína ligadora de fibronectina (FnBP) é um exemplo dos determinantes bacterianos que apresentam múltiplas

funções. Nesse caso, a proteína também é uma adesina para o fibrinogênio (WANN et al., 2000). As FnBPs têm sido propostas como fatores de virulência envolvidos com mastite 
bovina (SUTRA \& POUTREL, 1994). Pelo menos um dos genes codificadores dessa proteína é encontrado na maioria das linhagens de S. aureus (SMELTZER et al., 1997).

Por considerar a falta de dados que confirmem a importância das proteínas ligadoras de fibronectina na colonização da glândula mamária, BROUILLETTE et al (2003) desenvolveram um estudo que demonstrou uma redução de $30 \%$ na capacidade de aderir às células epiteliais mamárias bovinas em $S$. aureus DU5883, linhagem que perdeu as FnBPs, quando comparada ao tipo selvagem 8325-4. Essa linhagem de S. aureus que perdeu as FnBPs esteve presente em baixa proporção - em relação ao total composto por ela e o tipo selvagem - em momentos do experimento em que a pressão era menor que a da lactação, bem como na ausência dessa pressão. A baixa porcentagem de DU5883 encontrada em tecidos mamários confirmou, também, a diminuição da capacidade desse mutante em colonizar as glândulas sob uma pressão menor que a da lactação (BROUILLETTE et al., 2003). O experimento mostrou que as FnBPs de $S$. aureus conferem uma vantagem seletiva para a bactéria in vivo, pois são fatores de virulência para a colonização de glândulas mamárias em condições anteriores às do fluxo de leite. A capacidade de aderência às células, conferida por FnBPs, previne a eliminação de $S$. aureus durante a lactação.

Em oposição a outros estudos de aderência in vitro, este forneceu condições que melhor representam um meio natural encontrado durante uma infecção, como a presença de soro e leite e a incorporação de alguns fatores físicos semelhantes aos da lactação. Dessa forma, considerou a complexidade da inflamação e reações imunes que ocorrem durante o processo infeccioso da doença.

Os resultados de BROUILLETTE et al (2003) estão de acordo com alguns estudos anteriores. Um deles (DZIEWANOWSKA et al., 1999), utilizando a mesma linhagem selvagem de $S$. aureus 8325-4, mostrou que um mutante isogênico com ausência dos genes fnbps teve uma diminuição de 40\% na capacidade de aderir às células epiteliais de glândulas mamárias bovinas quando comparado à linhagem selvagem. Outro estudo (REDY \& ROSS, 2001) também mostrou que as FnBPs ajudam na aderência de $S$. aureus às células endoteliais da aorta bovina em condições que antecedem às do fluxo. A capacidade de adesão e permanência da linhagem S. aureus 8325-4 - em relação ao mutante que perdeu as FnBPs - foi observada somente quando a circulação do tampão usado no experimento foi interrompida por trinta minutos favorecendo a colonização da bactéria 
antes do recomeço do fluxo. Durante a circulação contínua, nenhuma aderência foi observada nas duas linhagens. Considerando que o fluxo de leite também não é contínuo durante a lactação, as observações feitas nesse estudo sugerem que a presença de FnBPs confere à bactéria a oportunidade de adesão entre as ordenhas.

Por outro lado, a importância das FnBPs foi questionada por FLOCK et al (1996) em um estudo no qual observou capacidades equivalentes em S. aureus 8325-4 e seu mutante isogênico com deleções de $f n b A$ e $f n b B$ para a colonização de válvulas danificadas. Esse experimento apresentou uma situação diferente da lactação, mas aponta para uma questão que pode ser comum nos processos de colonização de $S$. aureus, o fato de outra adesina poder compensar in vivo a ausência de FnBP. Um estudo já mostrou que a falta dessa proteína acentua a virulência de $S$. aureus em modelos de ratos com pneumonia (MC ELROY et al., 2002). No mesmo ano do estudo de FLOCK et al foi descoberto que a inativação do gene $f n b$ ocorre devido a uma inserção de um transposon, o Tn918, entre o gene fnb e seu promotor (GREENE et al., 1996).

Muitos estudos, como os apresentados até o momento, investigam o papel individual dos fatores relacionados à virulência por meio de clássicas inativações de genes, mas podem gerar resultados inconclusivos considerando a multiplicidade dos fatores patogênicos que são expressos por S. aureus. Como exemplo desse complexo contexto, QUE et al (2001) propõem que as quatro maiores adesinas de superfície, clumping factor A (ClfA), clumping factor B (ClfB) e as proteínas ligadoras de fibronectina A e B demonstram alta afinidade na ligação com seus alvos específicos in vitro, porém limitada relevância em experimentos in vivo. Os autores sugerem que uma explicação possível para o paradoxo in vitro/ in vivo seria a presença de fatores adicionais nos mutantes portadores de genes inativados que poderiam complementar, no processo da doença, a função das adesinas perdidas. Essa hipótese poderia explicar os resultados de MOREILLON et al (1995) em um estudo onde foi observado que mutantes com o gene clfA deletado mostraram diminuição do potencial infeccioso quando comparados com o progenitor positivo para esse gene, porém com essa diferença registrada somente para um número reduzido de bactérias. Outro estudo (STUTZMANN et al., 2001) que sugere um limitado envolvimento de clfA no processo de colonização mostrou que houve um aumento de 
aderência bacteriana ao se transferir o gene clfA para um hospedeiro, Streptococcus gordonii, mas a diferença entre esses organismos modificados e os que tiveram o gene transferido foi insignificante. Resultados como esses colocam em questão o uso dessa adesina como alvo primário em novas estratégias de tratamento antiestafilocócico (QUE et al., 2001) e, embora tenham sido obtidos de experimentos com modelos de endocardite, evidenciam a dificuldade de tornar precisa a importância de algumas adesinas no processo de colonização utilizando-se mutantes específicos para determinados genes, excluindo os múltiplos fatores de S. aureus.

QUE et al (2001) reavaliaram, ainda, o papel do clumping factor e das proteínas ligadoras de fibronectina de $S$. aureus. Esse estudo utilizou, como hospedeiro para os genes clfA e fnbA, o Lactococcus lactis, um recombinante muito menos capaz de induzir endocardites em ratos que Staphylococcus e Streptococcus. O sistema adotado na pesquisa permitiu a expressão de somente uma adesina na superfície do recombinante. Quando expressava ClfA, Lactococcus lactis adquiria a capacidade de aderir ao fibrinogênio e induzir endocardite em níveis similares aos expressos por S. aureus, o que levou os autores a identificar ClfA como uma adesina crítica capaz de mediar infecção endovascular. Assim como para ClfA, o recombinante revelou o efeito completo da proteína ligadora de fibronectina, uma vez que nenhuma adesina adicional estava presente em Lactococcus lactis. Esses resultados atribuem um papel crítico a essas adesinas em infecções endovasculares, reforçando os experimentos originais de KUYPERS \& PROCTOR (1989) em um estudo no qual utilizaram um isolado S. aureus, 879R4S, que carregava um único gene fnb e um mutante inativado para esse mesmo gene. Foi observado que o mutante teve menor capacidade de aderência do que a outra linhagem.

Um estudo recente (SUNG et al., 2008) mostrou que muitos genes conservados em isolados humanos como $f n b A$ e $f n b B$ apresentaram variações ou desapareceram em uma ou mais linhagens animais e, quando encontrados, não possuiam os quatro tipos de regiões correspondentes às quatro linhagens humanas seqüenciadas nesse trabalho, sugerindo que os isolados animais possuem regiões específicas próprias. Essas observações estão de acordo com os dados do projeto de seqüenciamento da RF122 (HERRON-OLSON et al., 2007), linhagem animal que apresentou uma única região com variações nos genes fnbA e fnbB. Nesse estudo, HERRON-OLSON et al (2007) utilizaram a linhagem ET3-1, que 
representa o clone mais comum de $S$. aureus isolado de casos de mastite bovina do mundo todo, e mostraram por meio de seqüenciamentos que muitos genes - envolvidos com a colonização do hospedeiro, produção de toxinas, regulação dos genes, metabolismo do ferro e resistência a antibióticos - apresentam uma alta relação entre substituições sinônimas e não sinônimas ( $d n: d s)$ se comparados aos genes dos isolados associados a humanos - o que talvez explique as variações entre as linhagens com relação a esses genes. O estudo descobriu também que o gene clfA é um pseudogene na linhagem ET3-1.

Quanto à freqüência do gene cna - codificador da proteína ligadora de colágeno em isolados animais, SMELTZER et al (1997) relataram que linhagens S. aureus geralmente não possuem esse gene. Em outro estudo mais recente (REINOSO et al., 2008), a detecção desse gene pôde ser efetuada somente para cinco linhagens humanas em um estudo de caracterização e comparação genotípica de isolados S. aureus de amostras humanas, mastite bovina subclínica e de alimentos. Poucos são os dados na literatura sobre essa adesina e sua atuação no processo de colonização da glândula mamária.

\subsection{Genes relacionados à produção de biofilme}

A formação de biofilme ocorre por meio de sucessivas etapas. A ligação inicial da bactéria a uma superfície sólida resulta em subseqüente proliferação e acúmulo de grupos de células em multicamadas e formação final de um reservatório bacteriano (STOODLEY et al., 2002). Esse reservatório de bactérias estrategicamente posicionadas dificulta a penetração e difusão de antimicrobianos e dos elementos de defesa do organismo (TRABULSI, 2004).

Um grupo de proteínas de superfície está emergindo como um importante elemento no processo de formação de biofilme de diversas espécies bacterianas. O primeiro membro desse grupo de proteínas foi identificado em um isolado $S$. aureus de mastite bovina como uma proteína essencial para a formação de biofilme (CUCARELLA et al., 2001) e foi denominado Bap (biofilm-associated protein). Esp, LapA e BapA, ao lado de Bap, são as outras proteínas desse grupo melhor caracterizadas até o momento.

A composição da matriz extracelular é complexa e pode variar entre espécies e até mesmo entre linhagens da mesma espécie dependendo das condições ambientais. Apesar da 
sua composição heterogênea, exopolissacarídeos são constantemente descritos como componentes essenciais dessa matriz fornecendo a estrutura onde as células microbianas são inseridas. Proteínas de superfície estão, também, freqüentemente na matriz do biofilme, mas sua presença tem sido principalmente relacionada com a ligação inicial das células microbianas às superfícies. O papel dessas proteínas na adesão intercelular e acúmulo em multicamadas de grupos de células ainda não está esclarecido (LASA \& PENADÉS, 2006).

A proteína Bap de $S$. aureus caracteriza-se por multidomínios de proteínas de superfície de bactérias Gram-positivas. O gene bap está contido em um transposon junto com o gene transposase e três genes codificadores de proteínas de um ATP-binding cassete $(A B C)$ transporter. Isso pode ser interpretado como coincidência ou como uma indicação de que o $(A B C)$ transporter pode estar envolvido direta ou indiretamente na secreção de Bap, como ocorre em bactérias Gram-negativas. Em bactérias Gram-positivas, o ( $A B C$ ) transporter não tem sido relacionado à mediação da secreção de Bap, apenas ao transporte de bacteriocinas e ferrormônios (LASA \& PENADÉS, 2006). O transposon está inserido em uma ilha de patogenicidade, SaPIbov2 (UBEDA et al., 2003) e sua mobilidade depende da atividade de uma recombinase funcional da família integrase que promove excisão, circularização e integração específica dentro do sítio att $_{\mathrm{B}}$ do cromossomo de $S$. aureus (LASA \& PENADÉS, 2006).

Estudos de ligação primária, agregação intercelular e formação de biofilme mostraram que Bap promove tanto a ligação primária a superfícies abióticas como a adesão intercelular. Uma vez que a interrupção do gene bap provoca a diminuição no acúmulo do principal exopolissacarídeo da matriz do biofilme de $S$. aureus, a primeira interpretação foi que a deficiência de biofilme em linhagens mutantes de bap era principalmente causada por diminuição do acúmulo desse exopolissacarídeo, o PIA/PNAG (LASA \& PENADÉS, 2006). A inativação do codificador de proteínas envolvidas na síntese de PIA/PNAG - o operon icaADBC - em uma linhagem bap positiva não teve efeito na formação de biofilme in vitro (CUCARELLA et al., 2004). Em direção semelhante a esses resultados, TORMO et al (2005) observaram que todos os isolados estafilocócicos testados que continham o gene bap eram fortemente produtores de biofilme, apesar da maioria deles não conter o operon ica $A D B C$. Esses resultados indicam que a proteína Bap é capaz de mediar um outro mecanismo de desenvolvimento de biofilme, alternativo ao mecanismo regular dependente 
de PIA/PNAG (LASA \& PENADÉS, 2006). O número de repetições de nucleotídeos dentro de Bap não foi relacionado até esse momento com a habilidade de formar biofilmes in vitro. Dessa forma, o fenótipo do biofilme de uma linhagem portadora da proteína Bap com uma única C-repeat é indistinguível de um biofilme produzido por uma linhagem que contém uma proteína Bap com trinta C-repeats (ARRIZUBIETA et al., 2004).

A aderência de $S$. aureus às proteínas solúveis e componentes da matriz extracelular do hospedeiro é uma das principais etapas da patogênese das infecções estafilocócicas. $S$. aureus apresenta uma família de adesinas denominada MSCRAMMs (microbial surface components recognizing adhesive matrix molecules) que reconhece especificamente componentes da matriz do hospedeiro. Estudos sobre a influência da presença de Bap na aderência de $S$. aureus às proteínas do hospedeiro, culturas de células epiteliais e regiões da glândula mamária têm indicado que linhagens bap positivas mostram aderência inferior ao fibrinogênio imobilizado, fibronectina e culturas de células epiteliais (CUCARELLA et al., 2002). Estudos experimentais de infecção da glândula mamária têm indicado que Bap pode atuar como um fator que impede a ligação bacteriana inicial aos tecidos do hospedeiro, embora, ainda que em longo período, a presença de Bap facilite a persistência de $S$. aureus na glândula mamária (CUCARELLA et al., 2004). O mecanismo pelo qual as proteínas da família Bap contribuem para o desenvolvimento do biofilme é desconhecido - apesar da grande proporção e do alto número de repeats sugerindo que essas proteínas possam mediar interações intercelulares homofílicas ou heterofílicas. Segundo LASA \& PENADÉS (2006), o papel dessas proteínas na virulência ainda está pouco claro.

\subsection{Toxinas estafilocócicas}

S. aureus sempre foi a espécie do gênero mais importante relacionada a uma série de infecções e intoxicações em humanos e nos animais. Vários fatores de virulência são responsáveis pelos sintomas e gravidade das infecções causadas pelo microrganismo. Esses fatores incluem as hemolisinas alfa, beta, delta e gama, as leucocidinas e um grupo de superantígenos tóxicos pirogênicos constituído pela toxina da síndrome do choque tóxico (TSST-1) e pelas enterotoxinas estafilocócicas (EEs) que causam intoxicações alimentares (BANNERMAN, 2003). 


\subsubsection{Citotoxinas}

As exotoxinas produzidas por Staphylococcus aureus com atividade em membranas compreendem as toxinas alfa, beta, delta e gama e as leucocidinas (BOHACH \& FOSTER, 2000).

\subsubsection{Alfa-toxina}

A alfa-toxina - denominada anteriormente de alfa-hemolisina devido à sua capacidade de lisar hemáceas - também atua na membrana celular de leucócitos promovendo a evasão do conteúdo da célula e conseqüente morte celular. É uma proteína citolítica que atua por meio da formação de poros em células sangüíneas e uma das toxinas bacterianas mais potentes. Suspeita-se que os eritrócitos de coelhos possuam um maior número de sítios de alta afinidade para a alfa-toxina, o que explicaria a ação especialmente tóxica dessa hemolisina a essas células, enquanto outras células menos sensíveis à ação da toxina, como os eritrócitos humanos, possuiriam apenas sítios com baixa afinidade (BOHACH \& FOSTER, 2000).

Os monômeros de alfa-toxina ligam-se à membrana celular formando hexâmeros ou heptâmeros, o que promove a formação de poros em forma de anel, os canais hidrofílicos (BHAKDI et al., 1991). Alterações no equilíbrio osmótico na entrada e saída de íons da célula e apoptose são efeitos decorrentes da formação desses poros e determinam a morte celular. Eritrócitos, células mononucleares, epiteliais, endoteliais e plaquetas são possíveis alvos da alfa-toxina que pode ser hemolítica, citotóxica, dermonecrótica e letal (BOHACH \& FOSTER, 2000). O gene codificador dessa hemolisina, hla, já foi clonado e seqüenciado (SAKO et al., 1983) e está sob o controle do sistema regulador agr. Alfa-toxina é produzida na fase pós-exponencial do crescimento bacteriano. 


\subsubsection{Beta-hemolisina}

Assim como a alfa-toxina, a beta-hemolisina é uma proteína que atua na membrana citoplasmática de várias células, apesar da denominação específica que recebe. Os poros formados na membrana tornam a célula instável e permitem o extravasamento do conteúdo celular. No entanto, esse processo é decorrente da atividade de esfingomielinase apresentada por beta-hemolisina, diferente da atuação de outras toxinas citolíticas. A hidrólise de esfingomielina, fosfolipídio encontrado na membrana, depende da síntese de beta-toxina que ocorre na fase pós-exponencial do crescimento bacteriano.

A beta-hemolisina - diferenciada da alfa-hemolisina por apresentar lise em eritrócitos de carneiro e não de coelhos - é produzida por aproximadamente $20 \%$ dos isolados S. aureus e sua identificação é relacionada principalmente a cepas de mastite bovina (BOHACH et al., 1997). A beta-hemolisina, de massa molecular $35 \mathrm{kDa}$, é também conhecida como toxina hot-cold devido a uma característica particular que apresenta quando inoculada em placas contendo ágar sangue de carneiro. A $37^{\circ} \mathrm{C}$, a toxina interage com as células sanguíneas vermelhas, mas não ocorre lise. Caso os eritrócitos sejam incubados em seguida a $4^{\circ} \mathrm{C}$, observa-se lise das células (HUSEBY et al., 2007).

O local ativo da beta-toxina é o centro inferior da proteína, como em todos os membros da superfamília DNase I. No entanto, um aspecto estrutural que individualiza as esfingomielinases (SMases) em relação aos outros membros dessa superfamília é a ocorrência de um filamento $\beta$, duplo e longo, formado pelas fitas $\beta 12$ e $\beta 13$ que interage com a cadeia $\mathrm{N}$-acil da esfingomielina. Em um estudo, HUSEBY et al (2007) testaram a capacidade de clivar a esfingomielina de um recombinante selvagem e dos mutantes H150N e H289N. A mutação His-150 ou His-289 suprimiu a atividade de esfingomielinase. Além disso, a capacidade de executar a lise hot-cold em eritrócitos de carneiro foi verificada usando as mesmas linhagens e observou-se uma redução de 60 e 200 dobras nos mutantes, respectivamente. OPENSHAW et al (2005) propuseram que o filamento duplo tem um papel significativo na penetração da membrana e preparação da clivagem da esfingomielina. No entanto, HUSEBY et al (2007) acreditam que isso seja improvável devido à conservação das características dos resíduos nesse filamento.

As diferenças de sensibilidade dos eritrócitos à beta-toxina relacionam-se com a quantidade de esfingomielina presente na constituição dessas células. MARSHALL et al 
(2000), usando ensaios biológicos e microscopia eletrônica, demonstraram que tanto linfócitos como neutrófilos também são sensíveis à beta-hemolisina e que a toxicidade da enzima é acentuada pela presença de $\mathrm{Mg}^{+2}$. No entanto, esses dois tipos de células são consideravelmente menos sensíveis que eritrócitos de carneiro, provavelmente devido à presença de menos esfingomielina na membrana dessas células (HUSEBY et al., 2007).

Importantes patógenos animais, como a linhagem de S. aureus NCTC 8325-4 (= RN4220), são conhecidos por secretarem grandes quantidades de beta-toxina, acima de $500 \mu \mathrm{g} / \mathrm{ml}$ e não eram associados a patogêneses humanas. HUSEBY et al (2007) mostraram, no entanto, que essa toxina afeta linfócitos sangüíneos periféricos humanos, especificamente por morte na proliferação de linfócitos T. Outras células humanas sensíveis à beta-toxina são os monócitos (WALEV et al., 1996), demais linfócitos e leucócitos polimorfonucleados (MARSHALL et al., 2000). A atuação da beta-toxina em linfócitos ocorre provavelmente com o intuito de promover a evasão da bactéria da maquinaria imune do hospedeiro e para auxiliar no processo de obtenção de nutrientes (HUSEBY et al., 2007). BOHACH \& FOSTER (2000) relataram que a atuação da betahemolisina é dependente da espécie, sendo os eritrócitos de carneiros, vacas e cobaias mais sensíveis que os eritrócitos humanos, enquanto os de murinos e caninos são resistentes à ação da toxina.

Um papel proposto para as hemolisinas como a beta-toxina é o de dotar os organismos com a capacidade de adquirir ferro da forma heme. Fontes potenciais de heme são hemoglobinas e mioglobinas que podem ser encontradas em eritrócitos (HUSEBY et al., 2007). O ferro é um nutriente limitante para todos os organismos e é necessário em muitos processos biológicos. S. aureus tem um sistema multicomponente de obtenção de heme de proteínas do hospedeiro de onde extrai o ferro essencial ao seu metabolismo (TORRES et al., 2006).

Os resultados do estudo de HUSEBY et al (2007) sugerem que a beta-toxina pode, também, contribuir com a modulação imune do hospedeiro na presença de fatores acessórios de virulência como os superantígenos. Quando linfócitos foram incubados com TSST-1 e beta-toxina, observou-se uma diminuição da quantidade de tritium incorporado no DNA. Para assegurar que era a beta-toxina que estava inibindo a incorporação de $\left[{ }^{3} \mathrm{H}\right]$ timidina, mutantes com alterações em seus sítios ativos foram construídos, H289N e 
H150N. Nenhum desses mostrou clivagem da esfingomielina in vitro e, quando testados para hemólise de eritrócitos de carneiro, pouca lise foi observada depois de 48 horas de incubação. A beta-toxina reduziu significativamente a incorporação de timidina na proliferação de células. TSST-1 causou proliferação de linfócitos identificada na forma de um grande número de colônias, provavelmente devido à ocorrência de linfócitos $\mathrm{T}$ contendo receptores específicos. Linfócitos incubados sem TSST-1 não formaram essas colônias. O efeito proliferativo caracterizado pela formação de colônias não ocorreu na presença de beta-toxina tanto nos isolados S. aureus como em E. coli.

As seqüências de aminoácidos codificadas pelo gene da beta-hemolisina $(h l b)$ são essencialmente idênticas em genomas conhecidos de S. aureus. As exceções são as linhagens em que os fagos $\$ 42$ e $\$ 13$ recombinam com a porção 5' final da beta-toxina produzindo fenótipos hlb mutantes (COLEMAN et al., 1991). Nas linhagens 8325-4, USA300, MSSA476, MRSA252 e MW2, isso resulta na deleção dos primeiros vinte e quatro resíduos da porção terminal amino da seqüência completa da beta-toxina. Os efeitos dessa troca incluem deleção do sinal de exportação e de $\beta 1$, filamento interno da folha $A$, explicando desse modo o fenótipo negativo. No caso da linhagem 8325-4, observa-se

produção de beta-toxina funcional quando é "curada" dos fagos $\phi 11$, ф12 e ф13 (COLEMAN et al., 1986). Nas linhagens N315 e Mu50, a inserção resulta em substituição dos resíduos 1-24 por uma determinada seqüência, longa o suficiente para repor o filamento $\beta 1$, mas isso poderia resultar em substituição dos resíduos hidrofóbicos Leu-10 e Val-13 por arginina e lisina, respectivamente. Não apenas o espaço seria insuficiente para esses largos resíduos, como essas trocas poderiam resultar na finalização de cargas avulsas, que são extremamente desestabilizantes (DAO-PIN et al., 1991), o que novamente produziria o fenótipo negativo.

\subsubsection{Delta-hemolisina}

Em 1947, Williams e Harper propuseram a existência da delta-hemolisina como uma quarta toxina citolítica de $S$. aureus, considerando as descritas até então, alfa, beta e gama. A delta-hemolisina é única em seu pequeno tamanho, estabilidade ao calor, propriedades surfactivas e é lítica para vários tipos de membrana da maioria das espécies animais, incluindo eritrócitos, outras células, organelas e até mesmo protoplastos 
bacterianos. A atuação de delta-hemolisina provoca vazamento citoplasmático e lise das células expostas a essa toxina (BOHACH \& FOSTER, 2000).

Codificado pelo gene hld - localizado próximo à porção final 5' do transcrito RNAIII do locus agr - esse peptídeo com vinte e seis resíduos é produzido por praticamente todos os isolados $S$. aureus e em alta porcentagem por outras espécies estafílocócicas. Quanto à localização e orientação da proteína em relação à membrana, pouco se sabe, mas parece que a toxina se insere dentro da bicamada lipídica, desordenando a estrutura da cadeia de lipídeos (BOHACH \& FOSTER, 2000).

\subsubsection{Leucotoxinas bi-componentes}

Entre os fatores de virulência de $S$. aureus, as leucotoxinas constituem uma família de toxinas formadoras de poros que, por terem como alvo células fagocíticas, provavelmente interferem nas defesas imunológicas (PREVOST et al., 2001). Gamahemolisina, leucocidina Panton-Valentine, LukE-D, a variante LukEv-Dv e lukM-lukF'-PV são exemplos de leucotoxinas bi-componentes, compostas por duas proteínas distintas secretadas independentemente e de ações sinérgicas.

Nenhuma informação sobre a existência de toxinas citolíticas formadoras de poros hetero-oligômericos em bactérias foi obtida até o momento, exceto em linhagens estafilocócicas (KANEKO \& KAMIO, 2004). Membros dessa família de toxinas apresentam uma distribuição epidemiológica e associações clínicas com determinadas doenças humanas ou com mastites de ruminantes leiteiros (BARRIO et al., 2006). As cepas S. aureus produtoras da toxina PVL e sua relação com casos de pneumonia adquirida na comunidade são um exemplo dessas associações. Após o primeiro relato feito por LINA et al (1999), outros casos foram descritos em instituições na França, Suíça, Holanda e Inglaterra, o que permitiu que os genes $p v l$ fossem adotados como marcadores estáveis para cepas CA-ORSA (HOLMES et al., 2005). Outro exemplo é a leucotoxina LukE-D que foi relacionada com cepas de $S$. aureus isoladas de pacientes com diarréia após o uso de antibióticos (GRAVET et al., 1999). No caso da toxina lukM-lukF’-PV, a associação com humanos não foi feita até o momento, pois os genes codificadores dessa proteína só foram encontrados em linhagens isoladas de mastite de ruminantes e não em linhagens de origem humana (FUEYO et al., 2005). 
As duas proteínas constituintes das toxinas bi-componentes são denominadas como subunidades de classe $\mathrm{S}(31-32 \mathrm{kDa})$ e de classe F (36-38 kDa). Por convenção, as denominações S e F (slow and fast) referem-se à velocidade com que as proteínas são eluídas de uma coluna cromatográfica de troca iônica de caboxi-metil-celulose. Pelo menos cinco classes de subunidades S (LukS-PV, HlgA, HlgC, LukE e LukM) e quatro classes de subunidades F (LukF-PV, HlgB, LukD e LukF'-PV) têm sido descritas em S. aureus (PREVOST et al., 2001).

Um componente, membro da classe $\mathrm{S}$, reconhece um receptor celular. Isso não produz nenhuma resposta da célula, mas possibilita que membros da classe F, junto com outros componentes S, associem-se em complexos hexa ou octaméricos que acionam atividades biológicas. A consecutiva associação com a membrana da célula alvo é rapidamente seguida pela ativação de canais de cálcio e pela formação de poros transmembrânicos que são permeáveis a cátions monovalentes como o etídium (PREVOST et al., 2001). O aumento da concentração de $\mathrm{Ca}^{2+}$ livre intracitoplasmático é relacionado com a ativação celular, um evento que acontece antes da formação do poro e abaixo das concentrações citotóxicas da toxina (STAALI et al., 1998).

Até o momento, foram caracterizados quatro loci codificadores de leucotoxinas bicomponentes: $h l g$, pvl, lukE-lukD e lukM-lukF`-PV, sendo os três primeiros investigados neste trabalho. O locus hlg, codificador da gama-hemolisina, é constituído por três ORF's que compreendem os genes $h \lg A, h \operatorname{lgC}$ e $h \operatorname{lgB}$, identificados por COONEY et al. (1993). As subunidades $\mathrm{HlgA}$ e HlgC pertencem à classe $\mathrm{S}$ e a subunidade $\mathrm{HlgB}$, à classe $\mathrm{F}$. Dessa forma, cepas portadoras do locus hlg podem formar duas combinações para a formação de toxinas: $\mathrm{H} \operatorname{lgB}$ e $\mathrm{H} \lg \mathrm{A}$ ou $\mathrm{H} \operatorname{lgB}$ e HlgC. No caso da leucocidina Panton-Valentine ou simplesmente PVL, o locus codificador é o luk-PV que possui como subunidade $\mathrm{S}$ o LukSPV e como subunidade F, LuKF-PV. Qualquer componente de uma proteína da classe S pode se combinar com outro da classe F. Essas combinações podem ser tóxicas e geram intensa resposta inflamatória (GRAVET et al., 1998). Uma cepa de S. aureus portadora do locus hlg e, também, do luk-PV terá seis possibilidades de combinações para a formação de toxinas. Um exemplo de associação preocupante é a interação de HlgA e LukD, fortemente indutora dos canais de cálcio (GRAVET et al., 1998). 
A atuação sinérgica das leucotoxinas é tóxica aos leucócitos polimorfonucleados, monócitos e macrófagos de coelhos e humanos e a associação HlgA e HlgB pode ter efeitos sobre alguns linfócitos $\mathrm{T}$ e eritrócitos humanos. A leucocidina LukE-D não tem forte ação hemolítica em eritrócitos humanos e quando comparada a outras leucocidinas é pouco tóxica aos leucócitos também (GRAVET et al., 1998). No entanto, entre as leucocidinas consideradas, LukE-D é a mais rápida na produção de efeitos como acumulação de fluidos, por exemplo. Neutrófilos e macrófagos podem ser lisados pela PVL, mas essa toxina não tem atividade hemolítica. Ao contrário, a gama-hemolisina tem forte atuação em hemáceas de humanos e outras espécies de mamíferos e é pouco leucotóxica. No entanto, o componente LukF-PV pode combinar com HlgC ou HlgA e promover atividade leucotóxica e pouco hemolítica. Apesar dos leucócitos polimorfonucleados, monócitos e macrófagos humanos serem alvos comuns das leucotoxinas estafilocócicas, essas toxinas não afetam sítios onde células típicas do sangue estão presentes. Segundo BOHACH \& FOSTER (2000), os alvos primários são as células especializadas na defesa do hospedeiro em tecidos moles como o folículo piloso, intestino e pulmão, até mesmo porque o sistema complemento do sangue parece inativar tanto a PVL como a gama-hemolisina.

Enquanto as atividades citotóxicas de algumas leucotoxinas entre neutrófilos polimorfonucleados humanos têm sido bem caracterizadas (FERRERAS et al., 1998), em neutrófilos polimorfonucleados de isolados de casos de mastite bovina essa caracterização tem ocorrido parcialmente (BARRIO et al., 2006). Em um de seus estudos, BARRIO et al (2006) compararam a atividade citotóxica de leucotoxinas que fazem parte do genótipo de linhagens causadoras de mastite - a gama-hemolisina, LukE-D e lukM-lukF`-PV - em seu alvo comum, o neutrófilo. Uma das observações dessa investigação foi a alta atividade da toxina LukM-LukF'-PV em neutrófilos polimorfonucleados bovinos, o que é condizente com um estudo anterior que determinou que isolados de mastite contendo lukM-lukF`-PV foram mais ativos em neutrófilos polimorfonucleados bovinos do que em isolados que perderam esses genes (RAINARD et al., 2003). Os genes lukM-lukF`-PV foram identificados no cromossomo da linhagem P83, originalmente isolada de um teto bovino infectado (KANEKO et al., 1997). BARRIO et al (2006) reforçam ainda que a atuação de LukE-D é caracterizada por ser a menos ativa em neutrófilos polimorfonucleados bovinos. No entanto, uma nova variante dessa toxina, LukEv-Dv, assim como em neutrófilos 
polimorfonucleados humanos, mostrou ter maior atividade que LukE-D em leucócitos de coelho. Essa variante foi identificada em uma linhagem de S. aureus, a ATCC 27733 (MORINAGA et al., 2003). Tanto LukE-D como LukEv-Dv não possuem um segmento que é fosforilado pela proteína quinase e essencial para a atividade leucocitolítica em PVL (KANEKO \& KAMIO, 2004). Dados do seqüenciamento completo dos genomas das linhagens N315 e Mu50 revelaram que $l u k E v-D v$ está em uma ilha de patogenicidade no cromossomo dessas linhagens (KURODA et al., 2001).

Ainda nesse estudo sobre a atuação das leucotoxinas em neutrófilos bovinos, BARRIO et al (2006) compararam as atividades das combinações homólogas das subunidades S e F e obtiveram o seguinte resultado: LukM-LukF'-PV > HlgA-HlgB > $\mathrm{HlgC} / \mathrm{HlgB}>\mathrm{LukEv}-\mathrm{LukDv}>\mathrm{LukE}-\mathrm{LukD}$. Os possíveis pares heterólogos de leucotoxinas também foram testados e LukM foi a mais ativa das subunidades $\mathrm{S}$ em combinação com todas as subunidades F. HlgB ou LukD mostraram um aumento na atividade em combinação com LukM, comparado com a atividade obtida com os seus homólogos da classe S. Em particular, a associação LukM-LukDv foi a segunda mais ativa, muito perto da atividade de LukM-LukF'-PV. LukDv foi também muito eficiente quando associada com $\mathrm{HlgA}$, mas $\mathrm{HlgA}$ e $\mathrm{HlgC}$ foram mais ativas com $\mathrm{HlgB}$ do que com qualquer outra subunidade da classe F. Em geral, LukE apresentou menor atividade. Esses dados indicam que algumas associações heterólogas são mais ativas que pares homólogos, a mais notável segundo esse estudo foi LukM-LukDv quando comparada com LukEv-LukDv. GRAVET et al (1998) já haviam demonstrado que pares heterólogos são ativos em alvos celulares e esse estudo mostrou que isso também se aplica aos neutrófilos polimorfonucleados bovinos.

A leucotoxina LukM-F'-PV parece particular de linhagens causadoras de mastite porque não é atribuída a isolados de outras origens e é associada às linhagens mais citotóxicas em neutrófilos polimorfonucleados bovinos (FUEYO et al., 2005). É também a mais ativa leucotoxina em neutrófilos polimorfonucleados bovinos, outro argumento que sustenta uma contribuição particular desta leucotoxina para a síndrome de mastite de ruminantes. LukE-D e LukEv-Dv são muito menos ativas em neutrófilos bovinos, embora quase todos os isolados de mastite tenham genes para essas toxinas (RAINARD et al., 2003). Esses dados podem sugerir que LukE-D é menos significativa em casos de mastite 
que LukM-LukF'-PV ou que, por outro lado, o alvo principal de LukE-D possa ser outro tipo celular (BARRIO et al., 2006).

Os resultados da análise da capacidade citotóxica das leucocidinas no estudo de BARRIO et al (2006) sugerem que a gama-hemolisina é mais eficiente em ativar do que lisar neutrófilos polimorfonucleados bovinos, o que parece possível, pois atividades de estimulação e lise da leucocidina PVL podem ser dissociadas sugerindo que essas duas funções das leucotoxinas estafilocócicas sejam formadas por diferentes partes da molécula (MOUSSA et al., 1999).

Comparando as atividades das mesmas leucotoxinas em neutrófilos polimorfonucleados humanos e bovinos, a principal diferença consiste na leucocidina PVL e LukM-LukF'-PV. Aquela é a mais ativa e esta a menos ativa em neutrófilos polimorfonucleados humanos e o contrário ocorre em neutrófilos polimorfonucleados bovinos (GRAVET et al., 1998).

\subsubsection{Toxinas com atividade de superantígenos}

O termo superantígeno (SAg) foi introduzido em 1989 por MARRACK \& KAPPLER para descrever uma acentuada expansão de células T em casos de exposição às toxinas que desencadeavam esse processo. As toxinas com atividade de superantígenos se ligam diretamente à molécula da classe II do complexo principal de histocompatibilidade (MHC II) das células apresentadoras de antígenos - uma forma diferente do que ocorre com os antígenos normais - resultando em uma estimulação de muitas células $\mathrm{T}$ e, conseqüentemente, em uma produção excessiva de citocinas como as interleucinas I (IL-1) e II (IL-2), gama interferon (IFN- $\gamma$ ) e fator de necrose tumoral (TNFa) (MARRACK \& KAPPLER, 1990).

O reconhecimento do antígeno pelo seu receptor, presente na membrana da célula $\mathrm{T}$, é a primeira etapa da resposta imune celular. O antígeno é apresentado a esses receptores na forma de peptídeos ligados às moléculas do complexo principal de histocompatibilidade (MHC), ou seja, ligados às proteínas associadas à membrana da célula apresentadora de antígeno. $\mathrm{O}$ comportamento dos superantígenos é caracterizado por interações inespecíficas com várias células $\mathrm{T}$. Para a ativação das propriedades dessas toxinas é necessário somente o reconhecimento de uma das porções da cadeia Beta do receptor de 
antígeno das células $\mathrm{T}$, a porção $\mathrm{V}$. De forma diferente, os antígenos convencionais, ao entrarem em contato com o MHC das células apresentadoras de antígenos, necessitam do reconhecimento dos cinco elementos do receptor de antígeno das células T, V-Beta, DBeta, J-Beta, V-Alfa e J-Alfa. Esse reconhecimento promove a ligação entre esse receptor e o MHC e explica por que os superantígenos conseguem estimular em torno de $20 \%$ de quase todos os linfócitos T, enquanto os antígenos convencionais estimulam essas células na ordem de 1:10.000 (McCORMICK et al., 2001).

As toxinas com propriedades de superantígenos (SAgs) produzidas por S. aureus compreendem as enterotoxinas estafilocócicas (SEs), a TSST-1 (toxic shock syndrome toxin-1) e as toxinas esfoliativas (ETs). Esses fatores de virulência estão envolvidos na patogênese de doenças estafilocócicas humanas como intoxicação alimentar, síndrome do choque tóxico e síndrome da pele escaldada (SCHMDT \& HENSEL, 2004), respectivamente. Entretanto, pouco é conhecido sobre a importância das toxinas com atividade de superantígenos na patogênese de infecções intramamárias bovinas, apesar de mais de $60-70 \%$ de $S$. aureus isolados desses casos produzirem essas toxinas ou carregarem seus respectivos genes (TOLLESRUD et al., 2000; KATSUDA et al., 2005).

\subsubsection{Enterotoxinas Estafilocócicas (SEs)}

As enterotoxinas produzidas por S. aureus causam intoxicação após a ingestão de alimentos contaminados por essas toxinas. A capacidade de produzir enterotoxinas estafilocócicas não é exclusiva de S. aureus. Estudos como o de HIROOKA et al (1988) relataram o isolamento de outras espécies coagulase positivas enterotoxigênicas como o $S$. intermedius e $S$. hyicus ${ }^{1}$.

Os principais sintomas como náuseas, vômitos, diarréias, dor abdominal e dor de cabeça ocorrem em um período de uma a seis horas após a ingestão da toxina. O quadro clínico é relativamente brando com duração de algumas horas a um dia podendo, às vezes, apresentar maior severidade em função da quantidade ingerida e da susceptibilidade do indivíduo e caracteriza-se por desidratação, cefaléia, sudorese e alteração da temperatura

\footnotetext{
${ }^{1}$ Recupero nesse texto, em parte, a revisão de literatura feita por CUNHA, M.L.R.S., publicada nos anais do IV encontro de pesquisadores em mastites realizado em Botucatu - SP, 2007.
} 
corpórea. As mortes são raras, mas já ocorreram em crianças e idosos (BENNETT et al., 1999).

A contaminação do leite com $S$. aureus pode ocorrer por duas vias principais, por meio da incorporação de microrganismos que estão presentes no úbere diretamente para o leite ou pelo contato do leite com utensílios e equipamentos contaminados durante as operações de ordenha, coleta e armazenamento (FAGUNDES \& OLIVEIRA, 2004). Considerando essa última situação, o homem pode atuar como reservatório de $S$. aureus e veiculador do microrganismo em alimentos (JAY, 2005). Segundo HUY (1994), 20 a 50\% das pessoas normais apresentam esse microrganismo na cavidade nasal e orofaringe e as cepas que estão no nariz podem passar para as mãos, dedos, pele, contaminando o ar, água, solo, alimento e qualquer superfície ou objeto que tenha entrado em contato com o portador (JAY, 2005).

As enterotoxinas estafilocócicas são proteínas solúveis em água, monoméricas, globulares com peso molecular entre 26 a 29 mil daltons, ricas em lisina, acido aspártico e glutâmico, com duas cisteínas formando ponte de dissulfeto (BERGDOLL, 1989). Apresentam resistência ao calor e às enzimas proteolíticas tripsina, pepsina, renina e papaína, o que permite a sua passagem pelo trato gastrintestinal sem perda de atividade (HUY, 1994). São termoestáveis e sua inativação depende da temperatura, da pureza, composição e pH do meio (NOTERMANS et al., 1988). Segundo o FDA (Food and drug administration, 2001), a toxina estafilocócica é sensível entre $98.9^{\circ} \mathrm{C}$ por 68,5 minutos ou $126,7^{\circ} \mathrm{C}$ por 6,2 minutos. O consumo de leite proveniente de rebanhos contaminados é um risco potencial à saúde humana, uma vez que a maioria dos casos diagnosticados de mastite é do tipo subclínico, ou seja, os animais não apresentam alterações visíveis na glândula mamária e no leite (FAGUNDES E OLIVEIRA, 2004).

As enterotoxinas estafilocócicas começaram a ser descritas em 1959 por BERGDOLL e colaboradores e, atualmente, constituem um grupo de dezoito toxinas sorologicamente distintas denominadas como EEA, EEB, EEC, EED, EEE, EEG, EEH, EEI, EEJ, EEK, EEL, EEM, EEN, EEO, EEP, EEQ, EER e EEU (JORGENSEN et al., 2005). As enterotoxinas estafilocócicas são similares na sua estrutura e propriedades biológicas (MARRACK \& KAPPLER, 1990). No entanto, diferem em relação à localização genética, sua produção e mecanismo de regulação do gene (CUNHA, 2007). Os 
genes sea e see, responsáveis pela produção das EEA e EEE, respectivamente são carreados em profagos (SCHAD et al., 1997). O gene seb, codificador da EEB, pode ser de origem cromossomal (SHAFER \& IANDOLO, 1978) ou pode ser carreado por plasmídios (SHALITA et al., 1977). As EEC são um grupo de proteínas de origem cromossomal altamente conservadas e apresentam três subtipos distintos, EEC1 EEC2 e EEC3 com base nas diferenças dos determinantes antigênicos (MARRACK \& KAPPLER, 1990). Outras variantes moleculares das EEC têm sido descritas de acordo com o hospedeiro animal a que está relacionada, EEC bovina, EEC canina e EEC ovina (MARR et al., 1993). Os genes sed e sej, determinantes das toxinas EED e EEJ, são de origem plasmidial. A EEJ apresenta seqüências similares com a EEA, EEE e EED correspondendo a 64, 63 e 51\% respectivamente. Análises feitas por BALABAN \& RASOOLY (2000) sugerem que o gene sej pode estar presente em todos os plasmídios que codificam a EED.

Ainda de acordo com CUNHA (2007), a quantidade em que são expressas também difere conforme o tipo de enterotoxina. Segundo BERGDOLL et al (1989), as EEB e EEC são expressas em maiores quantidades do que as outras enterotoxinas, freqüentemente na ordem de $100 \mu \mathrm{g} / \mathrm{ml}$ de sobrenadante de cultura, enquanto a produção máxima obtida para EEA, EED e EEE é geralmente menor que $10 \mu \mathrm{g} / \mathrm{ml}$. A quantidade de enterotoxina necessária para causar intoxicação ainda não foi exatamente estabelecida, mas considera-se que o consumo de um alimento contaminado com enterotoxinas estafilocócicas em concentrações de 1ng/g possa levar ao desencadeamento dos sintomas. Entretanto, fatores como idade, massa corpórea e condições físicas do indivíduo influenciam o desenvolvimento dos sintomas (CUNHA, 2007). Segundo BENNETT \& MONDAY (2003), o número de células de estafilococos necessárias à produção de enterotoxinas em quantidade suficiente para causar gastrenterite é de aproximadamente $10^{6} \mathrm{UFC} / \mathrm{g}$ ou $\mathrm{ml}$, sendo a EEA a mais comumente envolvida em surtos de intoxicação alimentar seguida da EED (JAY, 2005). A produção simultânea de diferentes tipos de toxinas, capacidade conferida a $S$. aureus, pode aumentar os efeitos toxigênicos isolados, sugerindo que essa co-produção possa desempenhar papel importante na patogenia das infecções intramamárias produzidas por esse microrganismo (FAGUNDES \& OLIVEIRA, 2004) como provocar distúrbios na reação de defesa do hospedeiro tornando-se uma das razões de infecções recorrentes e crônicas (HAVERI et al., 2008). 
Sabe-se, até o momento, que os genes para superantígenos podem existir em vários tipos de elementos genéticos móveis como fagos, plasmídios ou em ilhas de patogenicidade (SaPI) como, por exemplo, o locus egc. A maioria das toxinas codificadas por egc exibe atividade mitótica e pode atuar como superantígenos sendo potentes fatores de virulência que podem comprometer a reposta imune e criar vantagens para a bactéria. Isolados $S$. aureus que possuem SaPIbov (sec, sel e tst) podem inibir certos elementos como o egc1 devido a sua integração no cromossomo (HAVERI et al., 2008). Esses mesmos autores, também, identificaram a co-existência de egc2, e não egc1, em muitos isolados carreadores da SaPIbov, assim como encontrado em FUEYO et al. (2005).

\subsubsection{Toxina da Síndrome do Choque Tóxico (TSST-1)}

A toxina da síndrome do choque tóxico (TSST-1), por suas propriedades de superantígeno, estimula os linfócitos $\mathrm{T}$ a liberar citocinas que provocam o choque, uma condição sistêmica grave caracterizada por febre alta, vômito, diarréia, hipotensão arterial, descamação da pele, erupções cutâneas e acometimento de pelo menos mais três sistemas orgânicos (PARRILO et al., 1993). Para o desenvolvimento da síndrome do choque tóxico (TSS) é necessário que o hospedeiro esteja colonizado por uma cepa de S. aureus produtora de TSST-1 ou toxinas similares e que essas toxinas encontrem uma via de entrada na circulação sanguínea (HERZER, 2001). Com o intuito de realizar um diagnóstico preciso dessa síndrome, foi proposta a incorporação de análises laboratoriais - como isolamento de S. aureus de mucosa ou de sítios normalmente estéreis, produção de toxina associada à TSS pela cepa isolada, carência de anticorpos associados à toxina durante a fase aguda da doença - ao lado dos sintomas clínicos apresentados.

Em humanos, a TSS estafilocócica pode se manifestar de duas formas, a menstrual e a não-menstrual. A primeira ocorre em mulheres que possuem a mucosa vaginal colonizada por cepas de S. aureus produtoras de TSST-1, toxina com habilidade única entre as demais de cruzar as barreiras mucosas. Já a TSS não-menstrual pode resultar de infecção por S. aureus em qualquer local do organismo (McCORMICK et al., 2001). Em bovinos, tanto S. aureus isolados de casos clínicos como subclínicos de mastite

produzem essa toxina. O primeiro relato de detecção de TSST-1 produzida por S. aureus de origem animal foi feito por JONES e WIENEKE (1986). 
A TSST-1 é um polipeptídeo de cadeia simples com propriedades biológicas comuns a outras exotoxinas pirogênicas (CARDOSO et al., 2000). Essa toxina não está envolvida com intoxicação alimentar estafilocócica como as enterotoxinas. Entretanto, essas, por serem superantígenos, podem causar a forma não-menstrual de TSS pela ativação e proliferação de células T (KLOTZ et al., 2003), sendo esse papel atribuído às enterotoxinas dos tipos B (SEB) e C (SEC) (MCCORMICK et al., 2001).

Em S. aureus provenientes de bovinos, o gene tst, codificador de TSST-1 é encontrado em um elemento genético móvel. A linhagem ET3-1 foi o isolado fonte da descoberta e caracterização da SaPIbov1, uma ilha de patogenicidade associada a isolados S. aureus bovinos que codifica os genes para TSST-1 e uma variante da enterotoxina C estafilocócica associada a esses animais (FITZGERALD et al., 2001). As toxinas codificadas pelos genes sec e tst têm sido associadas à mastite bovina severa (JONES \& WIENEKE, 1986; MATSUNAGA et al., 1993).

\subsubsection{Toxinas Esfoliativas (ETs)}

A síndrome da pele escaldada estafilocócica (SSSS), uma das manifestações clínicas causadas por cepas produtoras de toxinas esfoliativas, coloca em questão a inclusão dessas toxinas no grupo de superantígenos devido à instabilidade dos sintomas apresentados. Embora ocorra estímulo específico de células $\mathrm{T}$ na presença dessa toxina, outros sintomas como eritema, febre e focos purulentos associados à síndrome mediada por superantígenos não ocorrem de forma sistemática. $\mathrm{O}$ fato da bactéria não ser isolada em todas as lesões bolhosas, decorrentes da atuação da toxina, ao lado da proliferação das células T, é o que confere a característica de superantígeno às toxinas esfoliativas (VATH et al., 1999).

As toxinas esfoliativas estafilocócicas (ETs) - produzidas por apenas 5\% das cepas

de S. aureus (BOHACH et al., 1997) - funcionam como serino-proteases, têm a quimiotripsina como protótipo contendo dois domínios em forma de barris perpendiculares e alfa-hélice C-terminal. A ETA possui uma única alfa-hélice N-terminal cuja ligação a um receptor celular ativa a protease (BOHACH \& FOSTER, 2000). Essas toxinas promovem uma separação intradérmica do estrato granular por meio da clivagem específica da desmogleína-1, proteína desmossomal mediadora da adesão intercelular dos queratinócitos presentes na camada granular. No caso da síndrome da pele escaldada, as manifestações 
clínicas podem ocorrer de forma generalizada pela epiderme ou localizada, sendo as lesões, nesse último caso, conhecidas como impetigo, podendo apresentar a formação de bolhas ou não. Quando se observa a ocorrência de bolhas, o líquido intradérmico é estéril e a cepa infectante geralmente é isolada de sítios distantes como garganta ou cavidade nasal (YAMASAKI et al., 2005). A descamação generalizada da pele ocorre em pacientes sem anticorpos para as toxinas esfoliativas, mas lesões localizadas, como o impetigo bolhoso, desenvolvem-se independente da presença do anticorpo no soro.

Foram descritas duas formas antigênicas de ETs, designadas como toxina esfoliativa A (ETA) e toxina esfoliativa B (ETB) e codificadas pelos genes eta e etb, respectivamente. A ETA é codificada por um gene cromossomal (eta) inserido em um segmento de $43 \mathrm{~Kb}$, enquanto o gene etb está em um plasmídio de aproximadamente 38,2 a 38,5 $\mathrm{Kb}$. ETA é uma toxina muito estável, resistente ao calor extremo, ao contrário de ETB, sensível ao calor (LISA, 2004). A associação dessas duas proteínas que apresentam mais de $40 \%$ de identidade (BOHACH \& FOSTER, 2000), em cepas de S. aureus, está relacionada a casos de dermatite esfoliativa humana em recém-nascidos, doença de Ritter, geralmente em surtos hospitalares (HELALI et al., 2005). A presença do gene etb é fortemente associada à síndrome generalizada, enquanto o gene eta relaciona-se com o impetigo bolhoso (YAMASAKI et al., 2005).

Comparada às outras toxinas pirogênicas, a ET é 100 vezes menos potente para induzir a proliferação de células T (MELISH \& GLASGOW, 1970) e, por razões ainda não esclarecidas, as toxinas esfoliativas não são co-produzidas com TSST-1 por S. aureus, embora isso ocorra com as demais enterotoxinas (GRAVET et al., 2001). 


\section{Objetivos}

\section{Gerais:}

Avaliar a diversidade genética, os principais fatores de virulência, genes assessórios agr e resistência a antimicrobianos de linhagens de Staphylococcus aureus e de outras espécies coagulase positivas isoladas de insufladores, do leite e de óstios bovinos e de leite de ovinos portadores de mastites clínica e subclínica.

\section{Específicos:}

1- Identificar os perfis clonais das linhagens de $S$. aureus e de outras espécies coagulase positivas por meio de eletroforese em campo pulsado (PFGE) e relacionar a ocorrência desses com a procedência das amostras.

2- Determinar os genes codificadores dos principais fatores de virulência de adesão, citotoxinas e toxinas com atividade de superantígenos de isolados de $S$. aureus e outras espécies coagulase positivas e relacioná-los com os perfis clonais obtidos.

3- Relacionar os genes codificadores dos fatores de virulência das linhagens de $S$. aureus com o grupo de genes assessórios agr.

4- Identificar perfis de sensibilidade aos antimicrobianos das cepas isoladas de insufladores, do leite e de óstios bovinos e de leite de ovinos portadores de mastites clínica e subclínica.

5- Avaliar a concentração inibitória mínima à oxacilina das cepas resistentes a este antibiótico. 


\section{Material e Métodos}

\subsection{Amostras bacterianas}

Foram analisadas 70 amostras de estafilococos coagulase positivos de origem animal. Dessas, 52 foram isoladas de amostras de leite de vacas com mastite subclínica, do óstio dos tetos desses animais e de insufladores empregados na coleta do leite de três fazendas de exploração leiteira do Município de Nova Odessa do Estado de São Paulo, correspondendo a 28, 16 e 8 isolados, respectivamente. Das 28 amostras de leite mastítico, 26 foram coletadas no período de outubro a dezembro de 2005 nas três fazendas, designadas por A, B e C. Já a coleta das outras duas amostras de leite mastítico e daquelas provenientes de óstios e de insufladores $(n=26)$ ocorreu apenas na fazenda A e durante um período mais extenso, de outubro/ 2005 a dezembro/ 2006, com exceção de uma única amostra que foi obtida de um insuflador nessa mesma fazenda em um período anterior, abril/ 2004. Essas 26 amostras foram previamente identificadas como ORSA. Quanto as 18 amostras de S. aureus isolados de ovinos da região do agreste do Município de Garanhuns do estado de PE, 6 foram isoladas de casos de mastite clínica e 12 de mastite subclínica.

\subsection{Metodologia}

\subsubsection{Identificação fenotípica das amostras de estafilococos coagulase positivos}

As amostras provenientes de bovinos e ovinos foram semeadas em caldo BHI (Brain Heart Infusion - DIFCO, Detroit, EUA) a $37^{\circ} \mathrm{C}$ por $18-24$ horas e, posteriormente, em ágar sangue a 5\% (Columbia Blood Agar, DIFCO, enriquecido com 5\% de sangue de carneiro desfibrinado) com incubação a $37^{\circ} \mathrm{C}$ por $18-24$ horas. As colônias foram submetidas ao exame bacterioscópico de esfregaços corados pelo método de Gram e aos testes da catalase e coagulase. A diferenciação de Staphylococcus aureus das demais espécies do gênero foi feita com base nos resultados das provas de Voges-Proskauer (VP), DNAse e produção de ácidos a partir de uma série bioquímica constituída de onze açúcares: maltose, frutose, sacarose, lactose, manitol, manose, rafinose, trealose, celobiose, xilose e 
arabinose. Até a realização das análises fenotípica e genotípica, as amostras bacterianas

foram conservadas em ágar TSA (Tryptone Soya Ágar - DIFCO, Detroit, EUA) à temperatura ambiente e caldo BHI (Brain Heart Infusion - DIFCO, Detroit, EUA) adicionado de glicerol na concentração de $25 \%$, a $-20^{\circ} \mathrm{C}$.

\subsubsection{Extração do DNA cromossômico}

A obtenção do DNA cromossômico das cepas para a realização das técnicas genotípicas foi realizada por meio da técnica de extração fenol-clorofórmio adaptada de SAMBROOK et al (1989).

As bactérias foram cultivadas por 24 horas a $37^{\circ} \mathrm{C}$ em caldo BHI. Dessa cultura, $1 \mathrm{ml}$ do meio foi centrifugado a $5000 \mathrm{rpm}$ por 10 minutos para a precipitação das células bacterianas. O sobrenadante foi descartado e o pellet ressuspendido em $500 \mu \mathrm{de}$ tampão de lise (50mM Tris, $\mathrm{pH} 8 ; 5 \mathrm{mM}$ EDTA pH 8; 50mM NaCl). Lisostafina a uma concentração final de $20 \mu \mathrm{l} / \mathrm{ml}$ foi adicionada para a digestão da parede celular e a solução incubada em banho-maria a $37^{\circ} \mathrm{C}$ por 2 horas. A membrana celular foi rompida com $30 \mu 1$ de uma solução de duodecil sulfato de sódio (SDS) a $20 \%$ e para a lise das proteínas presentes foi utilizada a enzima proteinase $\mathrm{K}(100 \mathrm{mg} / \mathrm{ml})$ a uma concentração final de $6 \mu \mathrm{l} / \mathrm{ml}$. Essa solução foi novamente incubada em banho-maria por 2 horas a $56^{\circ} \mathrm{C}$. Para a remoção das proteínas do meio foi realizada a separação de fases com $500 \mu$ de uma mistura de clorofórmio com álcool isoamílico (24:1). Após centrifugação a $5000 \mathrm{rpm}$ por 10 minutos, a fase superior foi transferida para outro tubo onde foram adicionados $700 \mu 1$ de etanol absoluto gelado e $50 \mu \mathrm{l}$ de $\mathrm{NaCl} 5 \mathrm{M}$ para a precipitação do DNA. Essa solução permaneceu a $-20^{\circ} \mathrm{C}$ por 12 horas e depois foi centrifugada a $15000 \mathrm{rpm}$ por 20 minutos. $\mathrm{O}$ sobrenadante foi descartado e nova centrifugação a $15000 \mathrm{rpm}$ por 20 minutos foi realizada com adição de etanol 70\% gelado. Após descarte do sobrenadante, o tubo permaneceu aberto no fluxo até evaporação total do etanol e o pellet foi solubilizado em $100 \mu$ de tampão TE (10mM Tris; $1 \mathrm{mM}$ EDTA - pH 8) e armazenado a $-20^{\circ} \mathrm{C}$ até ser utilizado. 


\subsubsection{Confirmação genotípica da espécie por meio da detecção do gene nuc}

Todos os isolados de estafilococos coagulase positivos selecionadas para esse estudo foram submetidas à confirmação da espécie por meio da identificação do gene nuc pela técnica da reação em cadeia da polimerase (PCR). O par de primers utilizado para a identificação de $S$. aureus foi desenhado com base nas seqüências de DNA genômico da cepa MRSA 252, incluídas no banco de dados GenBank (número de acesso NC_002952). O outro par de primers espécie-específico para a confirmação de $S$. intermedius amplifica regiões altamente conservadas nessa espécie, mas não em S. aureus (BECKER et al., 2005).

Tabela 1 - Iniciadores para amplificação dos genes nuc

\begin{tabular}{lll}
\hline Gene & Iniciador & Seqüência de nucleotídeos \\
\hline nuc - S. aureus & F & 5' - TATGGTCCTGAAGCAAGTG - 3' \\
& $\mathrm{R}$ & $5^{\prime}$ - GCCACGTCCATATTTATCAG - 3' \\
nuc - S. intermedius & $\mathrm{F}$ & $5^{\prime}$ - CCTGCAATGAGAGGTAAGTT - 3' \\
& $\mathrm{R}$ & $5^{\prime}$ - CAGACATTCAATATGCGATTC- 3' \\
\hline
\end{tabular}

Para as reações de amplificação foi utilizado um volume final de $25 \mu \mathrm{L}$ de uma mistura contendo $2 \mu \mathrm{L}$ da solução de DNA extraído conforme descrito em 3.2.2; 0,5 unidade de Taq DNA polimerase (Fermentas); 2,5 $\mu \mathrm{L}$ do tampão concentrado fornecido com a enzima; os reagentes com suas respectivas concentrações finais: $\mathrm{MgCl}_{2}$ a 2,5mM, cada dNTP a $200 \mu \mathrm{M}$ e os iniciadores a 250nM. As reações foram amplificadas em um termociclador Perkin-Elmer Gene Amp 2400 com as seguintes condições: uma denaturação inicial de 5 minutos a $94^{\circ} \mathrm{C}$ seguida de outros trinta ciclos de denaturação, cada um consistindo de 30 segundos a $95^{\circ} \mathrm{C}, 1$ minuto a $50^{\circ} \mathrm{C}$ e 2 minutos a $72^{\circ} \mathrm{C}$. A reação foi concluída com um ciclo de 5 minutos a $72^{\circ} \mathrm{C}$. Os produtos de PCR foram submetidos à eletroforese em gel de agarose conforme descrito no item a seguir. 


\subsubsection{Eletroforese em gel de agarose}

Para a visualização e análise do fragmento de DNA amplificado na reação da PCR, um gel de agarose foi preparado a 1,5\% em tampão 0,5X TBE (Tris base 890mM; EDTA $25 \mathrm{mM}$; ácido bórico $89 \mathrm{mM}$ ). Para a verificação dos tamanhos dos produtos da PCR, alíquotas dessas amostras, misturadas a uma solução tampão (azul de bromofenol 0,25\%; xileno cianol FF 0,25\%; glicerol 30\%), e um padrão de massa molecular conhecido ( $1 \mathrm{~Kb}$ DNA Ladder - InvitrogenTM) foram submetidos à separação eletroforética por cerca de 45 minutos a 100 volts. O gel foi corado com brometo de etídeo e visualizado em um transiluminador UV MacroVue (Pharmacia). O registro foi feito por fotografia digital.

\subsubsection{Determinação das linhagens de $S$. aureus e das demais espécies coagulase positivas por meio de eletroforese em campo pulsado (PFGE)}

As cepas de Staphylococcus aureus e das outras espécies coagulase positivas foram semeadas em ágar-sangue de carneiro a $5 \%$ e incubadas a $37^{\circ} \mathrm{C}$ durante 24 horas. Posteriormente, foram repicadas em caldo $\mathrm{BHI}$ e incubadas a $37^{\circ} \mathrm{C}$ por 24 horas. Após esse período, as amostras foram centrifugadas a $3.345 \mathrm{xg}$ durante 10 minutos e o sedimento foi ressuspendido em $1 \mathrm{ml}$ de solução salina estéril e transferido para um tubo de microcentrífuga previamente pesado. Essa suspensão foi centrifugada a $23.100 x g$ durante 15 minutos e o sobrenadante descartado. A seguir, o sedimento foi novamente ressuspendido com $1 \mathrm{ml}$ de solução salina estéril, centrifugado a $23.100 \mathrm{xg}$ durante 15 minutos e o sobrenadante, mais uma vez, descartado. Esse procedimento foi repetido três vezes e o sedimento, então, pesado e ressuspendido em EDTA 50mM pH 8,0 para uma concentração final de $100 \mu \mathrm{g}$ de massa bacteriana por $\mu 1$. Desta suspensão, $15 \mu 1$ foram transferidos para um tubo de microcentrífuga contendo $215 \mu 1$ de tampão EC. A essa mistura foram adicionados $250 \mu 1$ de agarose de baixo ponto de fusão a $\%$ (Sigma, USA) e $20 \mu 1$ de solução de lisostafina $(100 \mu \mathrm{g} / \mathrm{ml}$; Sigma, USA). Esta suspensão foi transferida para os moldes onde permaneceu por 30 minutos a $4^{\circ} \mathrm{C}$, para que os blocos se solidificassem. Após esta etapa, os blocos foram colocados em uma placa de cultura de células contendo $2 \mathrm{ml}$ de tampão EC em cada um dos orifícios. Essa placa foi incubada a $37^{\circ} \mathrm{C}$ por um período de 5 
horas sob agitação suave. Após a incubação, os blocos foram lavados com 2,5ml de tampão CHEF TE e, a seguir, incubados com $1 \mathrm{ml}$ de tampão ES adicionado de $50 \mu 1$ de solução de proteinase $\mathrm{K}\left(20 \mathrm{mg} / \mathrm{ml}\right.$ - Invitrogen USA) por 12 horas à temperatura de $50^{\circ} \mathrm{C} . \mathrm{Na}$ seqüência, os blocos foram lavados com 2,5ml de tampão CHEF TE e incubados à temperatura ambiente por 1 hora sob leve agitação (4 lavagens com incubações de uma hora cada). Foram armazenados nesta solução até serem submetidos à digestão enzimática e eletroforese (PFALLER, 1993).

Digestão enzimática - A digestão do DNA cromossômico foi realizada com a enzima de restrição FastDigest ${ }^{\circledR}$ SmaI (CCC $\downarrow$ GGG) (Fermentas Life Sciences, Canadá), que reconhece e cliva seqüências de nucleotídeos que aparecem poucas vezes ao longo do DNA de Staphylococcus spp (12 a 20 sítios de restrição) (PREVOST et al., 1992; STRUELENS et al, 1992). Para o tratamento com enzimas de restrição, um bloco de agarose de cada amostra foi transferido para uma placa de cultura de células de 96 orifícios contendo $300 \mu 1$ de tampão DNS. A seguir, esse tampão DNS foi retirado e novamente foram adicionados $300 \mu 1$ do mesmo tampão. Os blocos foram incubados à temperatura ambiente por 1 hora. Este processo foi repetido quatro vezes e, após este procedimento, o tampão DNS foi substituído por $100 \mu 1$ de uma solução contendo tampão FastDigest ${ }^{\circledR}$ 1X e $1 \mu 1$ da enzima FastDigest ${ }^{\circledR}$ SmaI. Em seguida, os blocos foram incubados por 6 minutos a $37^{\circ} \mathrm{C}$.

Eletroforese - A eletroforese em campo pulsado foi realizada em gel de agarose a 1\% (sigma, USA) em TBE 0,5X (90mM Tris; 90mM ácido bórico; 2mM EDTA Amersham Pharmacia Biotech, USA) (SAMBROOK et al., 1989) no equipamento CHEF DR1I System (BIO-RAD, USA) com intervalos de tempo de pulso de 5 a 60 segundos por 23 horas, ângulo de $120^{\circ}$, temperatura de $14^{\circ} \mathrm{C}$ e voltagem de 6,0 volts $/ \mathrm{cm}$ (PFALLER, 1993).

O gel foi corado com solução aquosa contendo $0,5 \mu \mathrm{g} / \mathrm{ml}$ de brometo de etídeo (Sigma, USA) e fotografado sob transiluminação com luz ultravioleta. Foi utilizado como padrão de peso molecular o Lambda DNA ladder PFGE (New England Biolabs, Inc., USA), com extensão das bandas de 48,5Kb até 1,0Mb (PFALLER, 1993).

Análise dos resultados - Os perfis de restrição do DNA gerados por PFGE foram analisados por dendrograma com utilização do coeficiente de similaridade DICE e tolerância de 2,0\%. 


\subsubsection{Antibiograma}

Para a avaliação do perfil de resistência das cepas em estudo, foi escolhida pelo menos uma droga de cada classe de antibióticos normalmente utilizados na determinação da sensibilidade de $S$. aureus aos agentes antimicrobianos. Foi empregado o método de difusão em ágar pela técnica de discos descrita por Kirby-Bauer (1966), padronizado pelo Clinical and Laboratory Standards Institute - CLSI (2008). Os discos de antibióticos

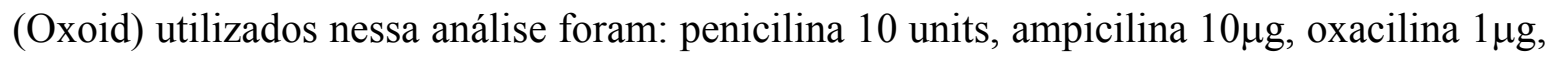
cefalotina $30 \mu \mathrm{g}$, vancomicina $30 \mu \mathrm{g}$, gentamicina $120 \mu \mathrm{g}$, amicacina $30 \mu \mathrm{g}$, eritromicina $15 \mu \mathrm{g}$, ofloxacina $5 \mu \mathrm{g}$, sulfametoxazol-trimetoprim $25 \mu \mathrm{g}$, tetraciclina $30 \mu \mathrm{g}$, cloranfenicol $30 \mu \mathrm{g}$, sulfonamida $300 \mathrm{mcg}$, azitromicina $15 \mathrm{mcg}$, clindamicina $2 \mu \mathrm{g}$ e ampi-sulbactam

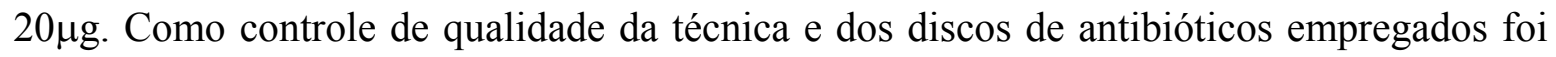
utilizada a cepa de $S$. aureus ATCC 25.923, conforme as normas preconizadas pelo CLSI (2008). A leitura dos halos foi feita no equipamento BIOMIC por meio do programa WHO NET 5 que converte as medidas dos halos em valores de concentração inibitória mínima (CIM).

\subsubsection{Confirmação da resistência à oxacilina}

Todas as cepas que apresentaram resistência à oxacilina por meio da técnica de discos foram submetidas a uma triagem para a confirmação de resistência a essa droga. Verificou-se o crescimento em ágar Müeller-Hinton contendo $4 \mu \mathrm{g} / \mathrm{mL}$ de oxacilina e $4 \%$ de

cloreto de sódio $(\mathrm{NaCl})$ conforme recomendações do Clinical and Laboratory Standards Institute - CLSI (2008). O inóculo foi aplicado na placa com auxílio de um swab embebido em uma suspensão da cultura bacteriana correspondente à escala 0,5 de McFarland. A incubação foi realizada a $35^{\circ} \mathrm{C}$ por $24 \mathrm{~h}$. A observação de uma ou mais colônias na área de aplicação do inóculo definiu o resultado como positivo, confirmando a resistência da cepa à oxacilina. As cepas de $S$. aureus utilizadas como controle foram a NCTC 10442, resistente à oxacilina e a ATCC 25923, sensível a esse antibiótico. 


\subsubsection{Determinação da concentração inibitória mínima (CIM) de oxacilina}

A determinação da CIM para a oxacilina foi realizada pela técnica de Etest (AB Biodisk, Solna, Suécia). Após cultivo em ágar sangue de carneiro, uma colônia foi inoculada em caldo Müeller-Hinton e incubada a $37^{\circ} \mathrm{C}$ até que a suspensão bacteriana atingisse a escala 0,5 de McFarland. Um inóculo dessa suspensão foi aplicado em ágar Müeller-Hinton por meio de um swab e a fita de Etest contendo diferentes concentrações de oxacilina foi colocada sobre o meio já inoculado. As placas foram incubadas a $35^{\circ} \mathrm{C}$ por 24h. A leitura foi realizada conforme as instruções do fabricante e a interpretação dos resultados segundo o documento do Clinical and Laboratory Standards Institute - CLSI (2008). As cepas de S. aureus utilizadas como controle foram a Mu50, resistente à oxacilina e a ATCC 25923, sensível a esse antibiótico.

\subsubsection{Determinação da presença do gene mecA}

Foi utilizado um par de iniciadores para a amplificação do gene mecA conforme demonstrado na tabela 2. Como controles positivos foram utilizadas cepas padrão de cada um dos quatro tipos de SCCmec: tipo I - NCTC 10442; tipo II - N315; tipo III - NCTC 85/2082; tipo IVa - JSC1968; tipo IVb - JSC1978 e tipo IVc - MR108. Como controle negativo foi usada a cepa ATCC 25923.

Tabela 2 - Iniciadores para amplificação do gene mecA

\begin{tabular}{lll}
\hline Gene & Iniciador & Seqüência de nucleotídeos \\
\hline \multirow{2}{*}{ mecA } & mA1 & $5^{\prime}-$ TGC TAT CCA CCC TCA AAC AGG - 3' \\
& mA2 & $5^{\prime}-$ AAC GTT GTA ACC ACC CCA AGA - 3' \\
\hline
\end{tabular}

Para amplificação do gene mecA foi utilizado o seguinte protocolo descrito por OKUMA et al (2002). Um volume final de $20 \mu \mathrm{L}$ de uma mistura para reação contendo $2 \mu \mathrm{L}$ de DNA; 0,5 unidade de Taq polimerase; $2,5 \mu \mathrm{L}$ do tampão concentrado fornecido com a enzima; os reagentes com suas respectivas concentrações finais: $\mathrm{MgCl}_{2}$ a $2,5 \mathrm{mM}$, cada dNTP a $200 \mu \mathrm{M}$ e os iniciadores a 250nM. As reações foram amplificadas no termociclador Perkin-Elmer Gene Amp 2400 com as seguintes condições: um ciclo de 5 minutos a $94^{\circ} \mathrm{C}$ 
seguido de trinta ciclos de amplificação, cada um consistindo de 30 segundos a $95^{\circ} \mathrm{C}, 1$ minuto a $50^{\circ} \mathrm{C}$ e 2 minutos a $72^{\circ} \mathrm{C}$. A reação foi concluída com um ciclo de 5 minutos a $72^{\circ} \mathrm{C}$. A visualização e análise dos fragmentos de DNA amplificados na reação da PCR foram realizadas conforme descrito no item 3.2.4.

\subsubsection{Reação em cadeia da polimerase (PCR) para amplificação das estruturas gênicas relativas aos fatores de virulência (toxinas)}

Foram utilizados 13 pares de iniciadores para a amplificação dos genes codificadores de toxinas, conforme demonstrado na tabela 3 (JARRAUD et al., 2002). Como controle interno para todas as reações de PCR foi utilizado o par de primers arcC, referente ao gene da proteína carbamato quinase. Para a amplificação das estruturas gênicas foi utilizado o protocolo descrito por OKUMA et al (2002) com algumas adaptações. Um volume final de $25 \mu \mathrm{L}$ de uma mistura contendo $2 \mu \mathrm{L}$ da solução de DNA extraído conforme descrito em 3.2.2; 0,5 unidade de Taq DNA polimerase (Fermentas); 2,5 $\mu \mathrm{L}$ do tampão concentrado fornecido com a enzima; os reagentes com suas respectivas concentrações finais: $\mathrm{MgCl}_{2}$ a $2,5 \mathrm{mM}$, cada dNTP a $200 \mu \mathrm{M}$ e os iniciadores a $250 \mathrm{nM}$. As reações foram amplificadas em um termociclador Perkin-Elmer Gene Amp 2400 com as seguintes condições: um ciclo de 5 minutos a $94^{\circ} \mathrm{C}$ seguido de trinta ciclos de amplificação, cada um consistindo de 30 segundos a $95^{\circ} \mathrm{C}, 1$ minuto a $55^{\circ} \mathrm{C}$ e 2 minutos a $72^{\circ} \mathrm{C}$. A reação foi concluída com um ciclo de 5 minutos a $72^{\circ} \mathrm{C}$. A temperatura de anelamento utilizada foi padronizada com testes em diferentes temperaturas e foi observado que a temperatura de $55^{\circ} \mathrm{C}$ aplicava-se a todos os iniciadores. A visualização e análise dos fragmentos de DNA amplificados na reação da PCR foram realizadas conforme descrito no item 3.2.4. A utilização das cepas N315 e Mu50 como padrões foi baseada no estudo de KURODA et al (2001). As outras cepas padrão foram gentilmente cedidas pela Dra. Teruyo Ito da Universidade Juntendo, Tóquio. 
Tabela 3 - Iniciadores para amplificação dos genes codificadores de toxinas

\begin{tabular}{|c|c|c|c|}
\hline Iniciador & Toxina & Seqüência $\left(5^{\prime}-3^{\prime}\right)$ & Cepa padrão \\
\hline SEA-1 & & GAA AAA AGT CTG AAT TGC AGG GAA CA & \\
\hline SEA-2 & Enterotoxina A & CAA ATA AAT CGT AAT TAA CCG AAG GTT C & Mu50 \\
\hline SEB-1 & & ATT CTA TTA AGG ACA CTA AGT TAG GGA & \\
\hline SEB-2 & Enterotoxina B & ATC CCG TTT CAT AAG GCG AGT & CC63 \\
\hline mpSEC-1 & & GTA AAG TTA CAG GTG GCA AAA CTT G & \\
\hline mpSEC-2 & Enterotoxina $\mathrm{C}$ & CAT ATC ATA CCA AAA AGT ATT GCC GT & N315 \\
\hline SED-1 & & GAA TTA AGT AGT ACC GCG CTA AAT AAT ATG & \\
\hline SED-2 & Enterotoxina D & GCT GTA TTT TTC CTC CGA GAG T & RN4220 \\
\hline SEE-1 & & CAA AGA AAT GCT TTA AGC AAT CTT AGG C & \\
\hline SEE-2 & Enterotoxina E & CAC CTT ACC GCC AAA GCT G & T47 \\
\hline TST-1 & TSST-1 Síndrome do & TTC ACT ATT TGT AAA AGT GTC AGA CCC ACT & \\
\hline TST-2 & choque tóxico & TAC TAA TGA ATT TTT TTA TCG TAA GCC CTT & N315 \\
\hline mpETA-1 & & ACT GTA GGA GCT AGT GCA TTT GT & \\
\hline mpETA-2 & Esfoliativa A & TGG ATA CTT TTG TCT ATC TTT TTC ATC AAC & $\mathrm{ZM}$ \\
\hline mpETB-1 & & CAG ATA AAG AGC TTT ATA CAC ACA TTA C & \\
\hline mpETB-2 & Esfoliativa B & AGT GAA CTT ATC TTT CTA TTG AAA AAC ACT C & N5 \\
\hline PVL-1 & Leucocidina Panton- & ATC ATT AGG TAA AAT GTC TGG ACA TGA TCC A & \\
\hline PVL-2 & Valentine & GCA TCA AAT GTA TTG GAT AGC AAA AGC & MR108 \\
\hline LUKDE-1 & & TGA AAA AGG TTC AAA GTT GAT ACG AG & \\
\hline LUKDE-2 & Leucocidina LukED & TGT ATT CGA TAG CAA AAG CAG TGC A & $\mathrm{N} 315$ \\
\hline HLA-1 & & CTG ATT ACT ATC CAA GAA ATT CGA TTG & \\
\hline HLA-2 & Hemolisina A & CTT TCC AGC CTA CTT TTT TAT CAG T & N315 \\
\hline HLB-1 & & GTG CAC TTA CTG ACA ATA GTG C & \\
\hline HLB-2 & Hemolisina B & GTT GAT GAG TAG CTA CCT TCA GT & RN4420 \\
\hline mpHLG-1 & & GTC AAA GAG TCC ATA ATG CAT TTA A & \\
\hline mpHLG-2 & Hemolisina gama & CAC CAA ATG TAT AGC CTA AAG TG & N315 \\
\hline
\end{tabular}

\subsubsection{Reação em cadeia da polimerase (PCR) para amplificação dos genes de adesinas e dos genes relacionados à produção de biofilme}

Foram utilizados 12 pares de iniciadores para a amplificação dos genes codificadores de adesinas e relacionados à produção de biofilme, conforme demonstrado na tabela 4 (TRISTAN et al., 2003; VANCRAEYNEST et al., 2004). Como controle interno para todas as reações de PCR foi utilizado o par de primers arcC, referente ao gene da proteína carbamato quinase. Para a amplificação das estruturas gênicas foram utilizadas as seguintes condições. Um volume final de $25 \mu \mathrm{L}$ de uma mistura contendo $2 \mu \mathrm{L}$ da solução de DNA extraído conforme descrito em 3.2.2; 0,5 unidade de Taq DNA polimerase 
(Fermentas); $2,5 \mu \mathrm{L}$ do tampão concentrado fornecido com a enzima; os seguintes reagentes com suas respectivas concentrações finais: $\mathrm{MgCl}_{2}$ a $2,5 \mathrm{mM}$, cada dNTP a $200 \mu \mathrm{M}$ e os iniciadores a $250 \mathrm{nM}$. As reações foram amplificadas em um termociclador Perkin-Elmer Gene Amp 2400 com as seguintes condições para os genes bbp, cna, eno, ebp, fnbA, fnbB, fib, clfA e clfB: um ciclo de 5 minutos a $94^{\circ} \mathrm{C}$ seguido de trinta ciclos de amplificação, cada um consistindo de 30 segundos a $95^{\circ} \mathrm{C}, 1$ minuto a $55^{\circ} \mathrm{C}$ e 2 minutos a $72^{\circ} \mathrm{C}$. A reação foi concluída com um ciclo de 5 minutos a $72^{\circ} \mathrm{C}$. Essas mesmas condições foram utilizadas para os genes icaA, icaD e bap, com exceção das temperaturas de anelamento que foram para esses, $47^{\circ}, 46^{\circ}$ e $52^{\circ}$, respectivamente. A visualização e análise dos fragmentos de DNA amplificados na reação da PCR foram realizadas conforme descrito no item 3.2.4.

Como controles positivos foram utilizadas as cepas: ATCC 25923 para os genes $b b p$, cna, eno e ebp; N315 para os genes icaA e icaD e, para os genes clfA, clfB, fnbA, fnbB e fib, algumas cepas da nossa coleção que tiveram seus produtos de PCR seqüenciados e comparados com as seqüências publicadas no GenBank (números de acesso Z18852, AJ224764, X95848, X62992 e X72014, respectivamente) com a utilização do software Blast.

Tabela 4 - Iniciadores para amplificação dos genes codificadores de adesinas e biofilmes

\begin{tabular}{|c|c|c|c|}
\hline Iniciador & Proteína & Seqüência $\left(5^{\prime}-3^{\prime}\right)$ & $\begin{array}{l}\text { Tamanho dos } \\
\text { fragmentos }\end{array}$ \\
\hline BBP-1 & Proteína ligadora de & AACTACATCTAGTACTCAACAACAG & $575 \mathrm{pb}$ \\
\hline BBP-2 & sialoproteína óssea & ATGTGCTTGAATAACACCATCATCT & \\
\hline CNA-1 & Proteína ligadora de & GTCAAGCAGTTATTAACACCAGAC & $423 \mathrm{pb}$ \\
\hline CNA-2 & colágeno & AATCAGTAATTGCACTTTGTCCACTG & \\
\hline ENO-1 & Proteína ligadora de & ACGTGCAGCAGCTGACT & $302 \mathrm{pb}$ \\
\hline ENO-2 & laminina & CAACAGCATCTTCAGTACCTTC & \\
\hline EBP-1 & Proteína ligadora de & CATCCAGAACCAATCGAAGAC & $186 \mathrm{pb}$ \\
\hline EBP-2 & elastina & CTTAACAGTTACATCATCATGTTTATCTTTG & \\
\hline FNBA-1 & Proteína A ligadora de & GTGAAGTTTTAGAAGGTGGAAAGAITAG & $643 \mathrm{pb}$ \\
\hline FNBA-2 & fibronectina & GCTCTTGTAAGACCATTTTTCTTCAC & \\
\hline FNBB-1 & Proteína B ligadora de & GTAACAGCTAATGGTCGAATTGATACT & $524 \mathrm{pb}$ \\
\hline FNBB-2 & fibronectina & CAAGTTCGATAGGAGTACTATGTTC & \\
\hline FIB-1 & Proteína ligadora de & CTACAACTACAATTGCCGTCAACAG & $404 \mathrm{pb}$ \\
\hline FIB-2 & fibrinigênio & GCTCTTGTAAGACCATTTTCTTCAC & \\
\hline CLFA-1 & Clumping factor $\mathrm{A}$ & ATTGGCGTGGCTTCAGTGCT & $292 \mathrm{pb}$ \\
\hline CLFA-2 & & CGTTTCTTCCGTAGTTGCATTTG & \\
\hline CLFB-1 & Clumping factor B & ACATCAGTAATAGTAGGGGGCAAC & $205 \mathrm{pb}$ \\
\hline
\end{tabular}




\begin{tabular}{llll}
\hline CLFB-2 & & TTCGCACTGTTTGTGTTTGCAC \\
ICAA-1 & Gene A de adesão & CCTAACTAACGAAAGGTAG & $1 \mathrm{~kb}$ \\
ICAA-2 & intercelular & AAGATATAGCGATAAGTGC & $450 \mathrm{pb}$ \\
ICAD-1 & Gene D de adesão & AAACGTAAGAGAGGTGG & $220 \mathrm{pb}$ \\
ICAD-2 & intercelular & GGCAATATGATCAAGATAC & \\
BAP-1 & Proteína associada à & CCCTATATCGAAGGTGTAGAATTG \\
BAP-2 & formação de biofilme & GCTGTTGAAGTTAATACTGTACCTGC \\
\hline
\end{tabular}

\subsubsection{Reação em cadeia da polimerase (PCR) para tipagem do sistema agr}

Para a pesquisa do grupo agr de $S$. aureus foram utilizados iniciadores específicos, sendo um universal e, portanto, comum para os quatro tipos de agr, o Pan. Esse e os outros quatro iniciadores específicos para cada um dos tipos de agr (GILOT et al., 2002) encontram-se na tabela 5 .

Tabela 5 - Iniciadores para tipagem do sistema regulatório agr

\begin{tabular}{lll}
\hline Iniciador & Seqüência (5’-3') & Cepas padrão \\
\hline Pan & ATG CAC ATG GTG CAC ATG C & \\
agr 1 & GTC ACA AGT ACT ATA AGC TGC GAT & $10 / 8520$ \\
agr2 & TAT TAC TAA TTG AAA AGT GGC CAT AGC & N315 \\
agr3 & GTA ATG TAA TAG CTT GTA TAA TAA TAC CCA G & ATCC 25923 \\
agr4 & CGA TAA TGC CGT AAT ACC CG & \\
\hline
\end{tabular}

As reações foram amplificadas no termociclador Perkin-Elmer Gene Amp 2400 com as seguintes condições: um ciclo de $94^{\circ} \mathrm{C}$ a 5 minutos, seguido de 30 ciclos de $94^{\circ} \mathrm{C}$ a 1 minuto, $57^{\circ} \mathrm{C}$ a 1 minuto e $70^{\circ} \mathrm{C}$ a 1 minuto. As reações foram concluídas com um ciclo de $72^{\circ} \mathrm{C}$ a 5 minutos. A visualização e análise dos fragmentos de DNA amplificados na reação da PCR foram realizadas conforme descrito no item 3.2.4. 


\section{Resultados}

\subsection{Identificação fenotípica das cepas de estafilococos coagulase positivos}

As 70 cepas de estafilococos coagulase positivos, sendo 52 provenientes de bovinos e 18 de ovinos, foram identificadas com base nos resultados da coloração de Gram e de testes fenotípicos. Desse total, 64 cepas foram identificadas como S. aureus, 4 como $S$. intermedius, 1 como S. schleiferi spp coagulans e 1 como S. delphini.

\subsection{Confirmação genotípica da espécie por meio da detecção do gene nuc}

Todas as cepas foram submetidas à confirmação da espécie por meio da identificação do gene nuc empregando-se primers específicos para a identificação de $S$. aureus e de S. intermedius. Das 70 cepas identificadas fenotipicamente como estafilococos coagulase positivos, 64 foram confirmadas genotipicamente como S. aureus e 4 como $S$. intermedius e as amplificações resultaram em fragmentos de aproximadamente 200 pb para as duas espécies. As cepas de S. schleiferi spp coagulans e S. delphini permaneceram com as identificações fenotípicas como descrito anteriormente. Como controles positivos para $S$. aureus foram utilizadas as cepas ATCC 25923 e N315. Essas mesmas cepas foram usadas como controles negativos para $S$. intermedius, na ausência de um controle positivo para essa espécie.

\subsection{Determinação das linhagens de $S$. aureus e demais coagulase positivos por meio de eletroforese em campo pulsado (PFGE)}

\subsubsection{Amostras bovinas provenientes das fazendas do Município de Nova Odessa - SP}

A análise do perfil de restrição do DNA das cepas de $S$. aureus provenientes de bovinos e insufladores por eletroforese de campo pulsado (PFGE) mostrou uma diversidade clonal maior na fazenda A. Foi possível identificar a ocorrência de 20 perfís clonais distintos entre 29 isolados, sendo 3 perfis provenientes de isolados de amostras de leite, 11 
de óstios bovinos e 6 de insufladores. Um isolado proveniente de insuflador obtido no período de outubro de 2005 a abril de 2006 apresentou o mesmo perfil clonal de outro isolado, também obtido de um insuflador, em coleta realizada dois anos antes, abril de 2004. Na fazenda B, os três isolados S. aureus provenientes de amostras de leite apresentaram o mesmo perfil clonal, também encontrado em isolados do leite na fazenda A. $\mathrm{Na}$ fazenda $\mathrm{C}$, observou-se a ocorrência de um único perfil clonal entre os 14 S. aureus isolados do leite, sendo 13 clones idênticos. Apenas uma cepa apresentou 90\%, e não 100\% de similaridade, com os demais isolados desse perfil clonal. Não houve relação clonal entre os isolados das amostras de leite, do óstio e de insufladores.

Com relação aos demais estafilococos coagulase positivos, todos provenientes de óstios de animais distintos da fazenda A, foi possível determinar os perfis clonais dos isolados S. schleiferi spp coagulans e S. delphini. Quanto aos isolados de S. intermedius, observou-se que dois apresentaram perfis clonais distintos e que as duas outras cepas dessa mesma espécie apresentaram resultados inconclusivos por PFGE, caracterizados por ausência de bandas ou "borrões".

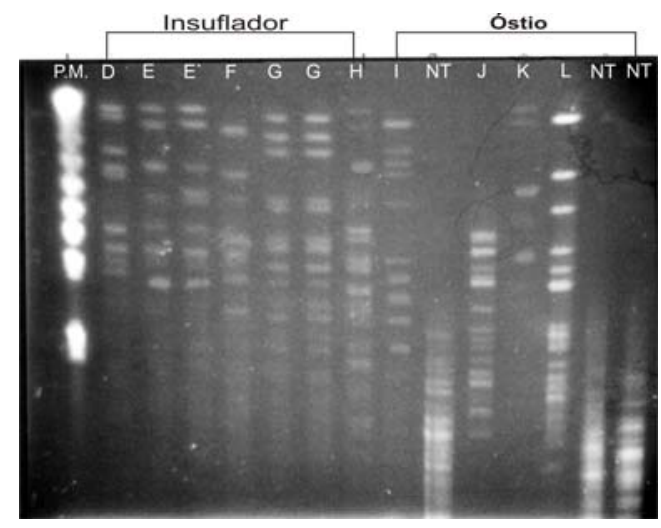

Coluna 1 - peso molecular (PM); colunas 2 a 8 - perfis clonais (D, E, F, G e H) das linhagens provenientes de insufladores da fazenda A; colunas 9, 11, 12 e 13 - perfis clonais (I, J, K e L, respectivamente) das linhagens provenientes de óstios bovinos da fazenda A; colunas 10, 14 e 15 - linhagens provenientes de óstios bovinos da fazenda A não tipáveis por PFGE (NT) com utilização da enzima de restrição SMAI.

Figura 1 - Perfis de restrição (PFGE) do DNA das cepas resistentes à oxacilina com utilização da enzima de restrição SMAI 


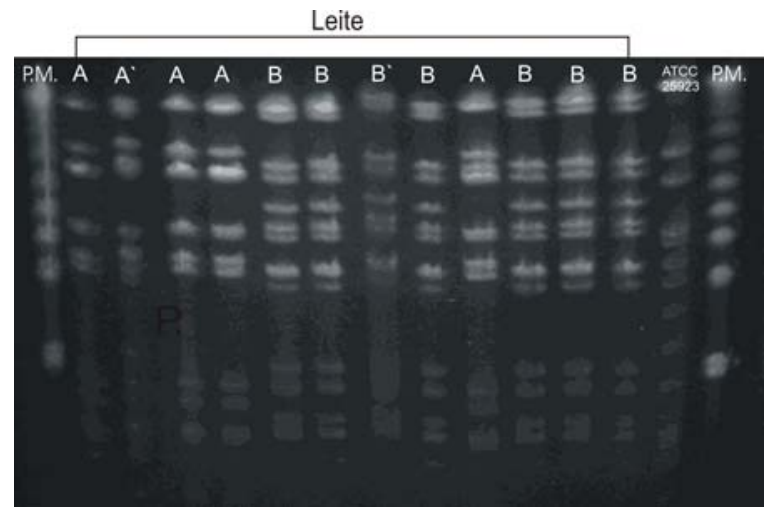

Colunas 1 e 15 - peso molecular (PM); colunas 2, 3, 4, 5 e 10 - perfil clonal (A) das linhagens provenientes de leite mastítico da fazenda A; colunas 6, 7,8 e 9 - perfil clonal (B) das linhagens provenientes de leite mastítico da fazenda A; colunas 11 a 13 - perfil clonal (B) das linhagens provenientes de leite mastítico da fazenda B; coluna 14 - perfil clonal da cepa padrão ATCC 25923.

Figura 2 - Perfis de restrição (PFGE) do DNA das cepas provenientes de amostras de leite mastítico bovino das fazendas A e B com utilização da enzima de restrição SMAI

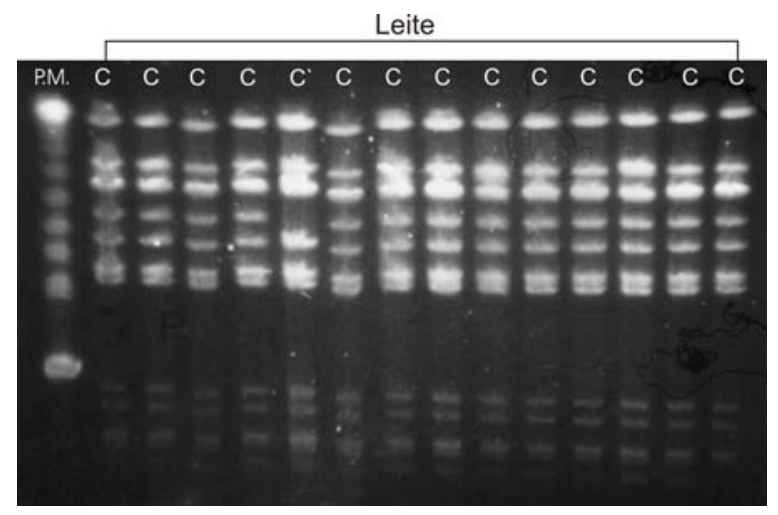

Coluna 1 - peso molecular (PM); colunas 2 a 15 - perfil clonal (C) das linhagens provenientes de leite mastítico da fazenda $\mathrm{C}$; coluna 6 - clone $\mathrm{C}^{\prime}$ com uma banda de diferença em relação às outras linhagens desse perfil clonal.

Figura 3 - Perfis de restrição (PFGE) do DNA das cepas provenientes de amostras de leite mastítico bovino da fazenda C com utilização da enzima de restrição SMAI 


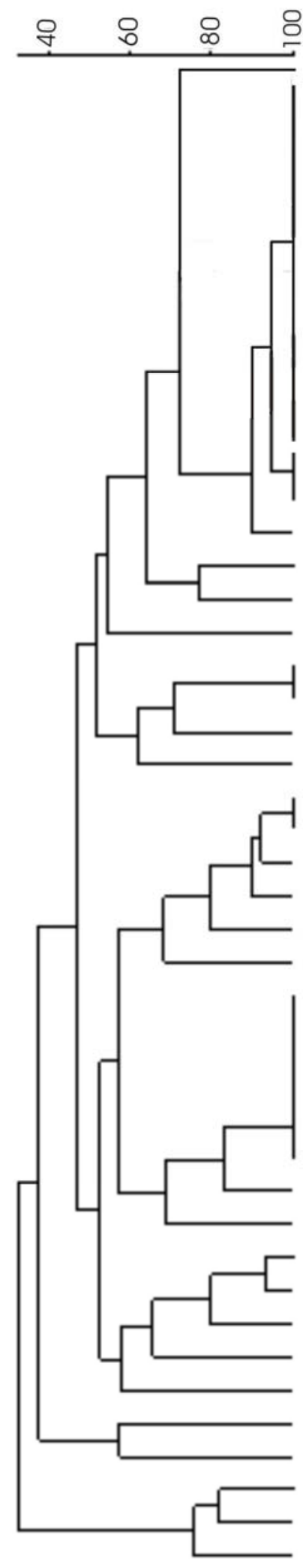

BOV OXA 24 - Fazenda A - perfil s

BOV 10 - Fazenda C - perfil C

BOV 11 - Fazenda $C$ - perfil C

BOV 12 - Fazenda C - perfil C

BOV 13 - Fazenda C - perfil C

BOV 6 - Fazenda C - perfil C

BOV 9 - Fazenda $C$ - perfil C

BOV 14 - Fazenda C - perfil C

BOV 1 - Fazenda $C$ - perfil $C$

BOV 2 - Fazenda $C$ - perfil $C$

BOV 3 - Fazenda $C$ - perfil C

BOV 4 - Fazenda $C$ - perfil C

BOV 7 - Fazenda $C$ - perfil C

BOV 8 - Fazenda $C$ - perfil $C$

BOV 5 - Fazenda $C$ - perfil C

BOV OXA 16 - Fazenda A - perfil M

BOV OXA 26 - Fazenda A - perfil U

BOV OXA 17 - Fazenda A - perfil N

BOV OXA 5 - Fazenda A - perfil $G$

BOV OXA 6 - Fazenda A - perfil $G$

BOV OXA 22 - Fazenda A - perfil R

BOV OXA 4 - Fazenda A - perfil F

BOV 3 - Fazenda A - perfil A

BOV 4 - Fazenda A - perfil A

BOV 1 - Fazenda A - perfil A

BOV 9 - Fazenda A - perfil A

BOV 2 - Fazenda A - perfil A'

BOV OXA 21 - Fazenda A - perfil Q

BOV 5 - Fazenda A - perfil B

BOV 6 - Fazenda A - perfil B

BOV 8 - Fazenda A - perfil B

BOV 1 - Fazenda B - perfil B

BOV 2 - Fazenda B - perfil B

BOV 3 - Fazenda B - perfil B

BOV 7 - Fazenda A - perfil B

BOV OXA 1 - Fazenda A - perfil D

BOV OXA 2 - Fazenda A - perfil E

BOV OXA 3 - Fazenda A - perfil E'

BOV OXA 25 - Fazenda A - perfil T

BOV OXA 11 - Fazenda A - perfil K

BOV OXA 7 - Fazenda A - perfil H

BOV OXA 18 - Fazenda A - perfil $O$

BOV OXA 8 - Fazenda A - perfil I

BOV OXA 12 - Fazenda A - perfil L

BOV OXA 19 - Fazenda A - perfil P

BOV OXA 10 - Fazenda A - perfil J

Figura 4 - Dendrograma das cepas coagulase positivas provenientes de bovinos e insufladores - SP 


\subsubsection{Amostras ovinas provenientes da região do agreste do Município de Garanhuns - PE}

A análise do perfil de restrição do DNA das cepas de $S$. aureus provenientes de ovinos por eletroforese de campo pulsado (PFGE) mostrou a ocorrência de quatro perfis clonais distintos, sendo três associados tanto a casos de mastite clínica como subclínica e o outro perfil apenas a casos de mastite subclínica. Entre os isolados de mastite clínica, a ocorrência do perfil clonal $\mathrm{Q}$ foi maior, seguido dos perfis $\mathrm{P}$ e R, correspondendo a 3, 2 e 1 isolados, respectivamente. O perfil clonal S não foi identificado em casos da forma mais severa de manisfestação da mastite. Quanto à distribuição dos perfis clonais em casos de mastite subclínica, observou-se maior freqüência do perfil $\mathrm{P}$, associado a cinco isolados e seguido dos perfis Q (clone mais freqüente nos casos de mastite clínica) e $\mathrm{S}$, cada um correspondendo a três isolados. Somente um isolado proveniente de mastite subclínica apresentou o perfil clonal R.

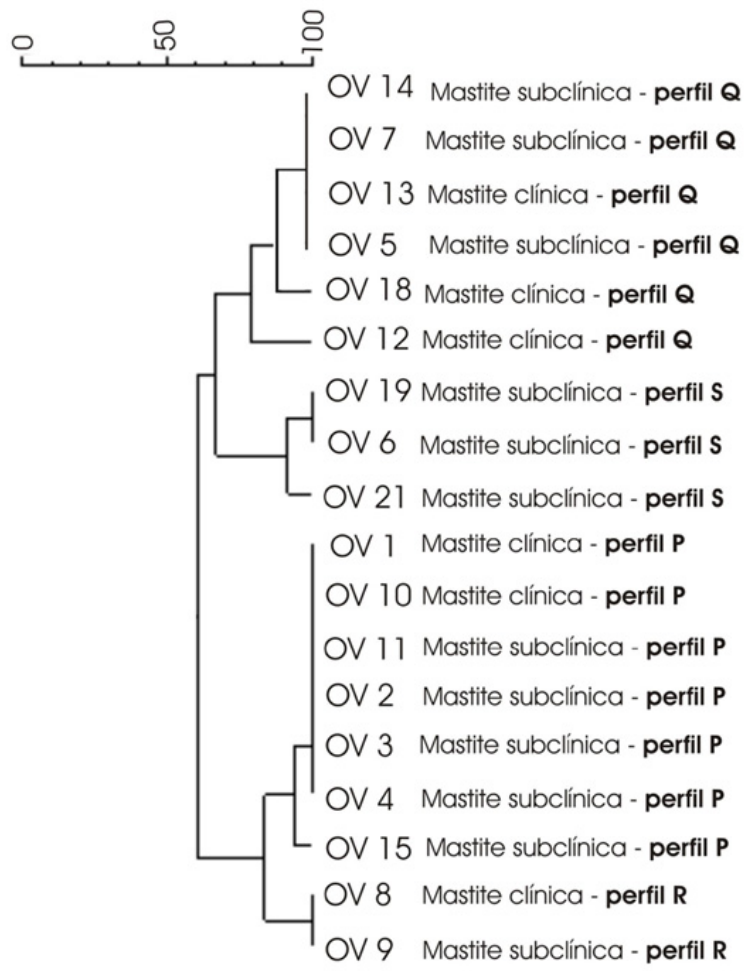

Figura 5 - Dendrograma das cepas $S$. aureus provenientes de ovinos - PE 


\subsection{Antibiograma}

A análise dos resultados dos antibiogramas permitiu a classificação dos isolados em seis perfis de susceptibilidade. O perfil 1 indica que a cepa é sensível a todas as drogas testadas. O perfil 2 é caracterizado por resistência à penicilina e ampicilina e sensibilidade aos demais antibióticos. Os perfis 3, 4, 5 e 6 incluem os isolados resistentes à oxacilina em ordem crescente de redução de sensibilidade aos demais antimicrobianos. Observou-se que os perfis com maior sensibilidade, 1 e 2, foram identificados apenas em isolados $S$. aureus de amostras de leite de vacas com mastite subclínica, o que corresponde a 49,4\% do total de isolados provenientes das fazendas do Estado de São Paulo. Os outros 50,6\% incluem as ORSA e demais estafilococos coagulase positivos resistentes à oxacilina. O perfil 3 foi o mais freqüente entre esses isolados resistentes à oxacilina, associado a 14 perfis clonais distintos. Todas as cepas S. aureus provenientes de leite de ovinos da região do agreste do Estado de PE apresentaram o perfil 1.

Tabela 6 - Perfis de susceptibilidade dos isolados provenientes de bovinos e ovinos

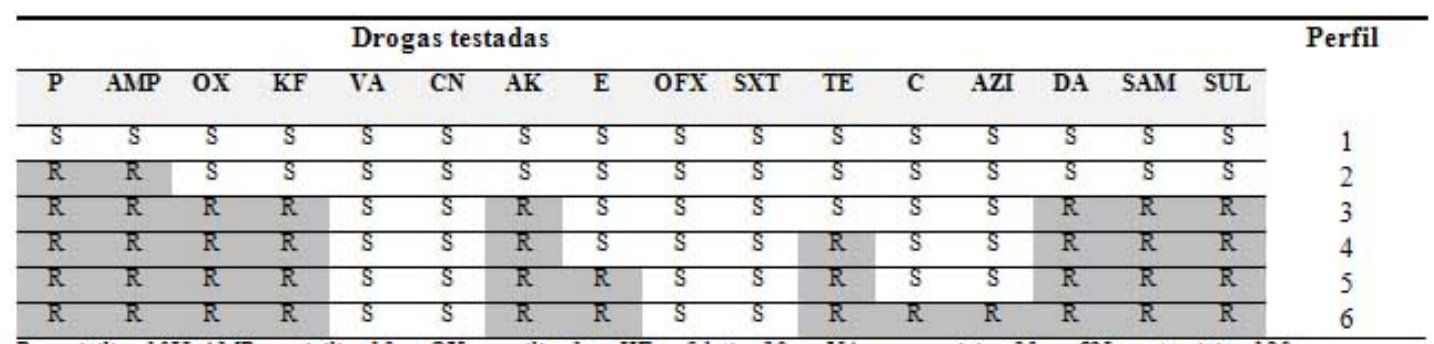

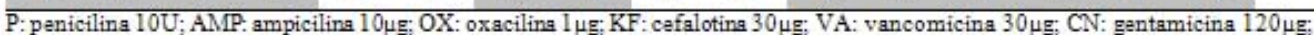
AK: amicacins $30 \mu \mathrm{g}$; E: eritromicina $15 \mu \mathrm{g}$; OFX: ofloxacina $5 \mu \mathrm{g}$; STX: sulfazotrin $25 \mu \mathrm{g}$; TE: tetraciclina $30 \mu \mathrm{g}$; C: cloranfenicol $30 \mu \mathrm{g}$ : AZI: azitromicina $15 \mathrm{mcg}$; DA: clindamicina $2 \mu \mathrm{g}$; SAM: ampicilina e sulbactam $20 \mu \mathrm{g}$; SUL: sulfonamida $300 \mathrm{mcg}$.

Tabela 7 - Distribuição dos perfis de susceptibilidade dos isolados provenientes de leite e óstios bovinose de insufla dores das fazendas do município de Nova Odessa - SP

\begin{tabular}{c|c|c|c|c}
\hline $\begin{array}{c}\text { Perfis de } \\
\text { susceptibilidade }\end{array}$ & \multicolumn{3}{|c|}{ Perfis clonais obtidos por PFGE } & Ocorrência entre os isolados (\%) \\
& Leite & Ostio & \\
\hline 1 & $\mathrm{~A} \mathrm{e} \mathrm{B}$ & & & 22,8 \\
\hline 2 & $\mathrm{C}$ & & $\mathrm{Insuflador}$ & 26,6 \\
\hline 3 & $\mathrm{M}$ & $\begin{array}{c}\mathrm{I}, \mathrm{J}, \mathrm{K}, \mathrm{L}, \mathrm{N}, \mathrm{O}, \mathrm{P}, \\
\mathrm{Q} \text { e NT }\end{array}$ & $\mathrm{D}, \mathrm{E}, \mathrm{F}, \mathrm{G}$ e H & \\
\hline 4 & & & $\mathrm{E}$ & 1,9 \\
\hline 5 & & $\mathrm{~S}$ & $\mathrm{R}$ & 3,8 \\
\hline 6 & & $\mathrm{~T} \mathrm{eU}$ & \multicolumn{2}{c}{} \\
\hline
\end{tabular}

${ }^{*}(\mathrm{NT})$ : isolados não tipáveis por PFGE com utilização da enzima de restrição SMAI. 


\subsection{Confirmação da resistência à oxacilina}

Os resultados positivos de resistência à oxacilina pela técnica de discos foram confirmados por screening para todos os isolados que apresentaram perfis de susceptibilidade 3, 4, 5 e 6, com exceção das espécies S. schleiferi spp coagulans e $S$. delphini.

\subsection{Determinação da concentração inibitória mínima (CIM) de oxacilina}

A maioria das cepas (70\%) com resistência confirmada tanto pela técnica de discos como pelo screening em ágar Müeller-Hinton apresentou uma concentração inibitória mínima (CIM) entre 1 e $8 \mu \mathrm{g} / \mathrm{mL}$, enquanto $25 \%$ apresentaram $12 \mu \mathrm{g} / \mathrm{mL}$ e $5 \%, 16 \mu \mathrm{g} / \mathrm{mL}$.

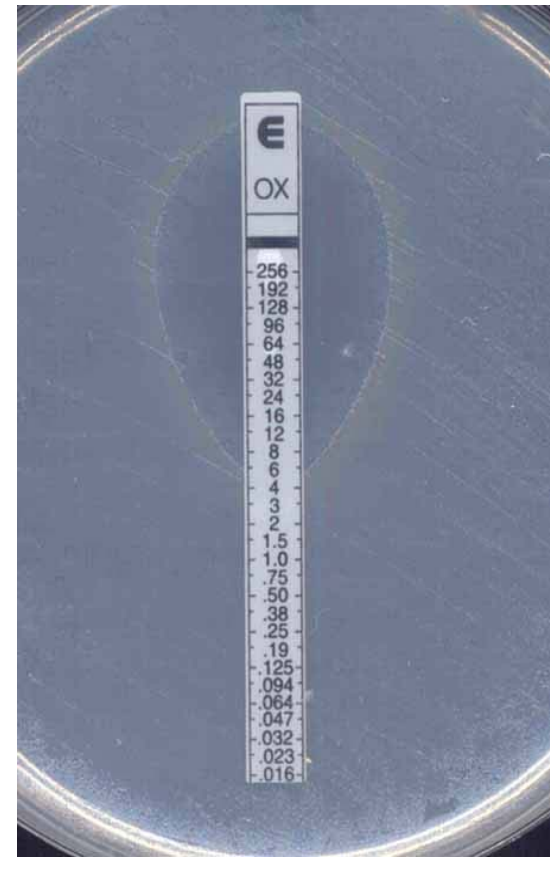

CIM de $6 \mu \mathrm{g} / \mathrm{mL}$

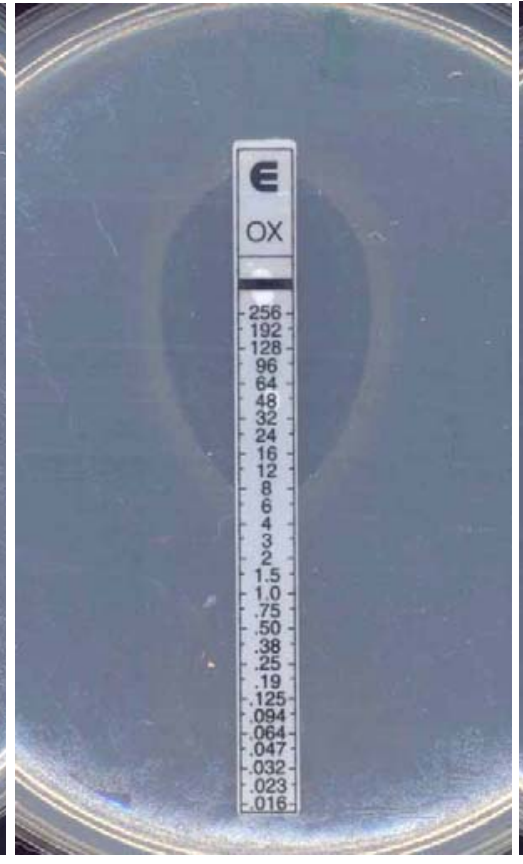

CIM de $8 \mu \mathrm{g} / \mathrm{mL}$

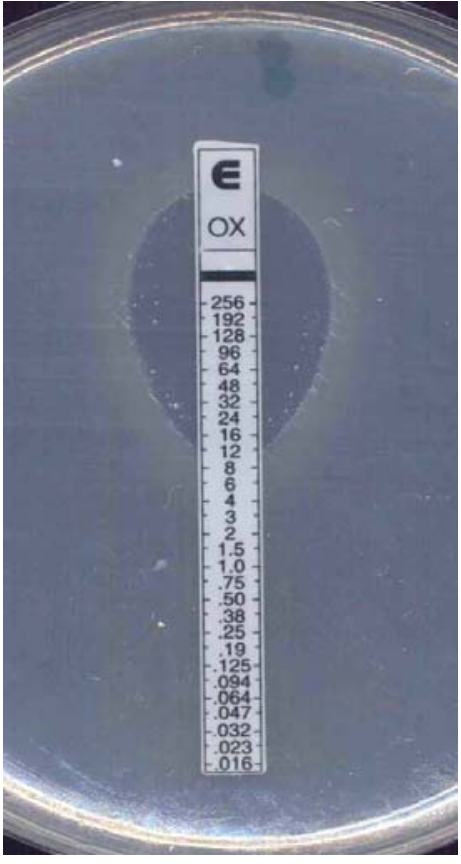

CIM de $12 \mu \mathrm{g} / \mathrm{mL}$

Figura 6 - Valores de concentração inibitória mínima (CIM) de oxacilina apresentados pelas cepas BORSA

\subsection{Determinação da presença do gene mecA}

Foram realizados testes genotípicos para a determinação do gene mecA das cepas com resistência à oxacilina e os resultados obtidos foram negativos para todos os isolados. 


\subsection{Fatores de virulência, grupo agr e os perfis clonais (PFGE) de S. aureus e outras espécies coagulase positivas provenientes de leite e óstios bovinos e de insufladores}

Tabela 8 - Distribuição dos genes codificadores dos fatores de virulência e grupo agr entre os perfis clonais (PFGE) de S. aureus e outras espécies coagulase positivas provenientes de leite e óstios bovinos e de insufladores

\begin{tabular}{|c|c|c|c|c|c|}
\hline "Origem & $\begin{array}{l}\text { Perfil } \\
\text { (PFGE) }\end{array}$ & $\begin{array}{l}\text { Grupo } \\
\text { agr }\end{array}$ & $\begin{array}{l}\text { Adesinas e genes } \\
\text { relacionados à produção de } \\
\text { biofilme }\end{array}$ & $\begin{array}{l}\text { Citotoxinas e Toxinas com } \\
\text { atividade de superantígenos }\end{array}$ & $\begin{array}{l}\text { Ocorrência } \\
\text { nos isolados } \\
(\%)\end{array}$ \\
\hline Leite mastítico & $\overline{\mathrm{A}}$ & NI & clfA & lukED & 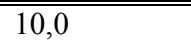 \\
\hline Leite mastítico & $\mathrm{B}$ & NI & clfA e eno & - & 14,0 \\
\hline Leite mastítico & $\mathrm{C}$ & II & clfA, clfB, eno, fnbA, fib e icaD & lukED, hla e $h l b$ & 28,0 \\
\hline Leite mastítico & $\mathrm{M}$ & NI & clfA & - & 2,0 \\
\hline Insuflador & $\mathrm{D}$ & II & $\begin{array}{l}\text { clfA, clfB, eno, fnbA, fib, icaD e } \\
\text { icaA }\end{array}$ & lukED, hla, hlb e eta & 2,0 \\
\hline Insuflador & $\mathrm{E}$ & NI & clfA e icaD & eta* & 4,0 \\
\hline Insuflador & $\mathrm{F}$ & NI & clfA & - & 2,0 \\
\hline Insuflador & $\mathrm{G}$ & NI & clfA e icaD & eta & 4,0 \\
\hline Insuflador & $\mathrm{R}$ & NI & clfA & & 2,0 \\
\hline Insuflador & $\mathrm{H}$ & NI & clfA & - & 2,0 \\
\hline Óstio & $\mathrm{I}$ & NI & clfA & eta & 2,0 \\
\hline Óstio & $\mathrm{J}$ & NI & clfA & - & 2,0 \\
\hline Óstio & $\mathrm{K}$ & NI & - & - & 2,0 \\
\hline Óstio & $\mathrm{L}$ & NI & - & - & 2,0 \\
\hline Óstio & $\mathrm{N}$ & NI & clfA & - & 2,0 \\
\hline Óstio & $\mathrm{O}$ & NI & clfA & - & 2,0 \\
\hline Óstio & $P$ & NI & - & - & 2,0 \\
\hline Óstio & Q & NI & clfA & - & 2,0 \\
\hline Óstio & $\mathrm{S}$ & NI & - & - & 2,0 \\
\hline Óstio & $\mathrm{T}$ & NI & clfA & - & 2,0 \\
\hline Óstio & $\mathrm{U}$ & NI & clfA & - & 2,0 \\
\hline Óstio & --- & NI & - & - & 4,0 \\
\hline Leite mastítico & --- & III** & clfA & - & 8,0 \\
\hline
\end{tabular}

(NI) Não identificado como os tipos agr I, II, III e IV; (---) Perfil não determinado por PFGE; * gene encontrado em apenas um dos dois isolados com o perfil clonal E; ** tipo agr encontrado em dois dos quatro isolados $S$. aureus sem identificação do perfil clonal; perfis clonais marcados com cinza correspondem às outras espécies coagulase positivas diferentes de S. aureus. 


\subsubsection{Genes relacionados à adesão e formação de biofilme}

Em relação às fazendas do Estado de SP, a análise genotípica do conteúdo de adesinas e proteínas associadas à formação de biofilme mostrou a ocorrência desses genes em todos as cepas $S$. aureus provenientes de óstios bovinos, do leite e de insufladores. Os perfis clonais C e D se destacaram em relação aos demais por apresentar pelo menos 50\% dos genes pesquisados relacionados à adesão e formação de biofilme e foram associados ao grupo agr II. O perfil clonal C foi encontrado em 14 isolados do leite da fazenda C e o perfil clonal D, identificado em uma única cepa proveniente de insuflador da fazenda $\mathrm{A}$. O grupo agr III foi identificado em apenas dois isolados de animais diferentes da fazenda A, um proveniente do leite e outro do óstio, ambos portadores de um único gene codificador de adesina. Os grupos I e IV de agr não foram identificados em nenhum dos isolados.

Os genes clfA (receptor para fibronectina) e eno (proteína ligadora de laminina) foram os mais freqüentes. O gene $c l f B$ (receptor para fibronectina) foi exclusivo dos isolados associados aos perfis clonais C e D, assim como o gene fib (proteína ligadora de fibrinogênio). Pelo menos um dos dois genes para receptores de fibronectina ( $c l f A, c l f B)$ foi encontrado entre os isolados. Quanto aos genes envolvidos com a produção de biofilme, $i c a D$ foi o mais freqüente, ao contrário de ica $A$, encontrado apenas em um isolado, ao lado de icaD. Os genes bbp (receptor para sialoproteína óssea), ebpS (proteína ligadora de elastina), cna (proteína ligadora de colágeno), fnbB (proteína ligadora de fibronectina) e bap (proteína relacionada à formação de biofilme) não foram identificados em nenhum dos isolados.

\subsubsection{Genes codificadores de citotoxinas e toxinas com atividade de superantígenos}

Ainda em relação às fazendas do Estado de SP, a pesquisa dos genes relacionados à produção de exotoxinas revelou que o perfil clonal predominante na fazenda C - o perfil C é portador dos genes codificadores das hemolisinas A e B e da leucocidina LukED. O perfil clonal D, encontrado em outra fazenda, apresentou os mesmos genes do perfil C e, também, o gene eta. Esse gene, codificador da toxina esfoliativa A, foi encontrado em aproximadamente $10 \%$ dos isolados, sendo todos S. aureus e associados com os perfis D, 
E, G e H determinados por PFGE. Não houve uma relação entre esses portadores do gene eta e um grupo agr específico, ao contrário dos perfis clonais $\mathrm{C}$ e $\mathrm{D}$, caracterizados pela presença de múltiplos genes codificadores de exotoxinas e associados ao grupo II de agr. O perfil clonal $\mathrm{A}$ foi associado apenas à presença do gene codificador da leucocidina LukED. Não foram identificados portadores da gama-hemolisina e dos genes codificadores da toxina bi-componente Panton-Valentine (PVL) e da toxina da síndrome do choque tóxico (TSST-1). A ausência dos genes para as enterotoxinas A-E foi outra característica dessas cepas.

\subsection{Fatores de virulência e os perfis clonais (PFGE) dos demais estafilococos coagulase positivos provenientes de bovinos}

Foi possível determinar a ocorrência de quatro perfis clonais por PFGE entre os seis isolados coagulase positivos diferentes de S. aureus, provenientes de óstios bovinos distintos. Dois desses perfis clonais foram associados a cepas de $S$. intermedius, um ao isolado S. schleiferi spp coagulans e outro ao S. delphini. Os seis isolados apresentaram resultados negativos tanto para os genes codificadores de adesinas e aqueles envolvidos com a produção de biofilme como para os genes determinantes de exotoxinas. A única exceção foi um isolado $S$. intermedius que teve fragmentos amplificados para os genes clfA e icaD, porém com tamanhos diferentes do esperado, $700 \mathrm{pb}$ e $800 \mathrm{pb}$, respectivamente, ao contrário de $292 \mathrm{pb}$ e $450 \mathrm{pb}$. A identificação do grupo agr não se aplica para S. schleiferi spp coagulans e $S$. delphini e os isolados da espécie $S$. intermedius foram negativos para os grupos I, II, III e IV desse sistema regulador. 


\subsection{Fatores de virulência, grupo agr e os perfis clonais (PFGE) de $S$. aureus provenientes de ovinos}

Tabela 9 - Distribuição dos genes codificadores dos fatores de virulência e grupo agr entre os perfis clonais (PFGE) de S. aureus provenientes de ovinos

\begin{tabular}{|c|c|c|c|c|c|}
\hline Origem & $\begin{array}{l}\text { Perfil } \\
\text { (PFGE) }\end{array}$ & $\begin{array}{l}\text { Grupo } \\
\text { agr }\end{array}$ & $\begin{array}{l}\text { Adesinas e genes } \\
\text { relacionados à produção de } \\
\text { biofilme }\end{array}$ & $\begin{array}{l}\text { Citotoxinas e Toxinas com } \\
\text { atividade de superantígenos }\end{array}$ & $\begin{array}{l}\text { Ocorrência } \\
\text { nos isolados } \\
\text { (\%) }\end{array}$ \\
\hline m. clínica & $\overline{\mathrm{P}}$ & 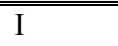 & clfA & hla, lukED e tst & 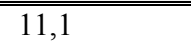 \\
\hline m. subclínica & $\mathrm{P}$ & I & clfA & $h l a, h l b, l u k E D$ e $s e c$ & 27,5 \\
\hline m. clínica & Q & II & $c l f A$ e $c l f B$ & hla e lukED & 16,6 \\
\hline m. subclínica & Q & II & $c l f A$ e $c l f B$ & hla, lukED, tst e sec & 16,6 \\
\hline m. clínica & $\mathrm{R}$ & I & clfA e icaD & hla e lukED & 5,5 \\
\hline m. subclínica & $\mathrm{R}$ & I & clfA e icaD & lukED & 5,5 \\
\hline m. subclínica & $\mathrm{S}$ & II & clfA & - & 16,6 \\
\hline
\end{tabular}

\subsubsection{Genes relacionados à adesão e formação de biofilme}

Em relação à região do agreste do Estado de $\mathrm{PE}$, os isolados $S$. aureus provenientes de ovinos de um mesmo perfil clonal não apresentaram diferenças quanto ao conteúdo genético relacionado às adesinas e proteínas associadas à formação de biofilme considerando a severidade da mastite. A presença do gene clfA foi identificada em 100\% das cepas. Em associação a esse gene, os isolados de perfil clonal Q apresentaram, também, o $c l f B$ (receptores para fibronectina), independente de sua ocorrência em mastite clínica ou subclínica. O mesmo ocorreu com os isolados de perfil clonal $\mathrm{R}$, foram portadores da combinação clfA (receptores para fibronectina) e icaD (adesão intercelular), independente da forma de manifestação da doença.

Quanto ao sistema agr, tanto o grupo I como o II foram associados aos casos de mastites clínica e subclínica. Os grupos III e IV não foram encontrados em nenhum dos isolados. Os genes $b b p$ (receptor para sialoproteína óssea), ebpS (proteína ligadora de elastina), cna (proteína ligadora de colágeno), $f n b B$ (proteína ligadora de fibronectina), icaA 
e bap (proteínas relacionadas à formação de biofilme) não foram identificados em nenhum dos isolados.

\subsubsection{Genes codificadores de citotoxinas e toxinas com atividade de superantígenos}

Ainda em relação à região do agreste do Estado de $\mathrm{PE}$, observou-se entre os isolados S. aureus provenientes de ovinos uma alta freqüência dos genes hla e lukED, 77,6 e $83,1 \%$, respectivamente. No entanto, não houve uma relação específica entre a presença desses genes com a severidade da mastite. Da mesma forma, não foi possível determinar se uma combinação maior dos genes associados às exotoxinas relaciona-se com a mastite clínica ou subclínica. No caso dos isolados associados aos perfis clonais $\mathrm{P}$ e Q, presentes nas duas formas de manifestação da doença, observou-se maior combinação dos genes codificadores de exotoxinas naqueles provenientes de mastite subclínica e o contrário foi observado para o perfil clonal R. Os isolados associados a esse perfil apresentaram maior combinação desses genes em casos de mastite clínica. Quanto às enterotoxinas estafilocócicas, foi identificada a presença do gene sec, codificador da enterotoxina tipo C, em $44,4 \%$ dos isolados. Outro gene determinante de toxina com atividade de superantígeno, o tst, foi encontrado em $27,7 \%$ dos isolados, sendo que em 16,6\% desses estava associado ao gene sec.

Não houve uma relação específica entre os grupos agr I e II, identificados nas cepas provenientes de ovinos, e as combinações dos genes codificadores de citotoxinas e de toxinas com atividade de superantígenos. Não foram encontrados portadores de hlg (gama-

hemolisina), pvl (genes codificadores da toxina bi-componente Panton-Valentine) e dos genes sea, seb, sed e see (enterotoxinas A, B, D e E). 


\section{Discussão}

As linhas de ordenha mecânica são importantes fontes para a transmissão de Staphylococcus spp em rebanhos leiteiros, uma vez que esses equipamentos podem estar contaminados com bactérias provenientes da pele do teto do animal, do leite ou de manipuladores humanos. A análise dos resultados obtidos por meio da eletroforese de campo pulsado (PFGE) mostrou alta diversidade genética entre as linhagens de S. aureus isoladas de amostras de leite mastítico bovino, do óstio dos tetos desses animais e dos insufladores analisados de uma das três fazendas de exploração leiteira selecionadas para a realização desse trabalho, a fazenda A.

Por outro lado, o perfil clonal $\mathrm{B}$, associado aos três isolados $S$. aureus provenientes de amostras de leite mastítico de outra fazenda, designada como fazenda $\mathrm{B}$, também foi encontrado em amostras de leite da fazenda A, indicando possível transmissão cruzada desta linhagem entre os animais das duas fazendas.

$\mathrm{Na}$ fazenda $\mathrm{C}$ houve a ocorrência de um perfil clonal (C) predominante entre as linhagens de S. aureus. Os isolados associados a esse perfil são provenientes de amostras de leite coletadas de nove animais diferentes portadores de mastite subclínica, um indicativo de disseminação clonal por possível falta de condições adequadas de higiene durante a ordenha. Esse perfil clonal (C) correspondeu a $28 \%$ do total de isolados do Estado de SP e caracterizou-se pela presença de genes codificadores de hemolisinas, leucotoxinas, adesinas e genes relacionados à formação de biofilme. Ao lado do perfil clonal D, obtido de um insuflador e encontrado em apenas $2 \%$ do total de isolados, foi o que apresentou maior combinação dos fatores de virulência.

Quanto aos insufladores, foi possível detectar, entre outros diferentes perfis, a ocorrência de dois isolados S. aureus pertencentes a um mesmo perfil clonal (G), sendo um deles identificado em coleta realizada nos mesmos equipamentos dois anos antes do período de coleta do atual isolado. Como os insufladores foram trocados nesse período de tempo, pode-se inferir a presença de $S$. aureus nas canulações ou contaminações recorrentes. Considerando as três fontes de origem das cepas, o óstio dos tetos bovinos foi o ambiente que apresentou maior diversidade clonal, levando a acreditar que sejam bactérias da própria microbiota do animal ou, talvez, contaminação humana. 
Em relação às outras espécies coagulase positivas diferentes de $S$. aureus, todas originadas de óstios bovinos, foi possível determinar os perfis clonais dos isolados $S$. schleiferi spp coagulans e S. delphini e identificar a ocorrência de dois perfis distintos entre as linhagens de $S$. intermedius. No entanto, para duas cepas dessa espécie, assim como para quatro isolados S. aureus - sendo um proveniente do leite e três de óstios bovinos - todos da mesma fazenda, observou-se ausência de bandas no gel submetido à eletroforese de campo pulsado. Esses resultados podem ser conseqüência de uma nova enzima presente nesses isolados que promove a metilação do DNA nos sítios de atuação da enzima de restrição SMAI, impedindo, dessa forma, a tipagem dos isolados com essa característica pela técnica de PFGE. Atualmente, uma considerável proporção dos casos de mastite deve-se à ocorrência cada vez mais freqüente de linhagens genomicamente diversificadas e portadoras de múltiplos fatores de virulência, associadas tanto a hospedeiros animais como humanos. Linhagens não tipáveis por PFGE e denominadas, por essa razão, de NT-MRSA (non-typable methicillin-resistant Staphylococcus aureus) e NT-MSSA (non-typable methicillin-sensible Staphylococcus aureus) têm sido associadas em pesquisas recentes ao complexo clonal ST398 definido por MLST (BENS et al., 2006) e sua ocorrência tem aumentado significativamente tanto entre porcos e fazendeiros que trabalham com esses animais como em pacientes com bacteremia, sugerindo que essas linhagens são bastante virulentas (BELKUM et al., 2008). Os isolados deste estudo não tipáveis por PFGE, ao contrário, apresentaram um reduzido número de genes codificadores dos fatores de virulência aqui pesquisados.

Quanto aos isolados S. aureus provenientes de ovinos, foi possível determinar quatro perfis clonais por PFGE. Desses, três foram comuns aos casos de mastite clínica e subclínica (perfis P, Q e R) e como apenas 33,2\% das amostras foram isolados de mastite clínica não podemos fazer a associação desses perfis com a severidade da doença. Somente o perfil S foi exclusivo de mastite subclínca e, ao contrário dos outros perfis clonais, foi o que apresentou menor número de genes codificadores dos fatores de virulência.

A análise genotípica do conteúdo de adesinas e proteínas associadas à formação de biofilme mostrou uma distribuição desses genes em $100 \%$ dos isolados S. aureus provenientes de leite mastítico bovino, do óstio dos tetos desses animais e de insufladores. 
A combinação dos fatores de virulência dos isolados S. aureus originados do óstio, independente do perfil clonal, foi caracterizada pela pouca ocorrência dos genes relacionados ao processo de colonização. Diferentes perfis clonais encontrados nesse ambiente apresentaram uma característica em comum, foram portadores apenas do gene cflA. Isso pode sugerir que esses isolados não estejam relacionados com o estabelecimento da mastite ou que essa relação aconteça por meio de outros fatores não pesquisados neste estudo. Pode-se supor, ainda, que essa característica seja uma adaptação da bactéria ao ambiente do canal do teto bovino e do úbere, que por incluir a presença de leite durante a lactação, entre outros fatores, difere de outros sítios comuns de infecção e pode contribuir com as diferenças apresentadas por essas linhagens em relação aos genes codificadores de proteínas expressas na superfície. Apenas um isolado proveniente do óstio foi portador de outro gene além do $c f l A$, o eta, codificador da toxina esfoliativa, o que pode ser um indício de contaminação humana.

Quanto aos isolados S. aureus provenientes do leite mastítico e dos insufladores, dois perfis clonais se destacaram quanto ao conteúdo genético relacionado ao processo de colonização. O perfil clonal $\mathrm{D}$, representado por um único isolado, apresentou maior combinação dos genes codificadores dessas proteínas, seguido do perfil $\mathrm{C}$, associado a quatorze isolados de outra fazenda. Uma combinação caracterizada pela presença dos genes codificadores das proteínas que se ligam ao fibrinogênio, fibronectina, laminina e dos genes relacionados à adesão intercelular diferencia os perfis clonais $\mathrm{C}$ e D dos demais isolados pela multiplicidade dos fatores de virulência. Nesse estudo, o gene fnbA, codificador da proteína ligadora de fibronectina, foi exclusivo desses dois perfis clonais e o gene fnbB não foi encontrado em nenhuma das amostras analisadas. Segundo PEACOCK et al (2002), fnbA (proteína ligadora de fibronectina) e cna (proteína ligadora de colágeno) são os genes de adesinas relacionadas à parede celular associados com maior freqüência a isolados invasivos humanos. Os perfis clonais $\mathrm{C}$ e $\mathrm{D}$, identificados aqui, apresentaram o gene fnbA e, também, fib e eno, codificadores das proteínas ligadoras de fibrinogênio e laminina, respectivamente, o que sugere que esses isolados tenham vantagens em relação aos demais quanto à capacidade de invadir tecidos. A combinação dos fatores de virulência dos isolados com perfis $\mathrm{C}$ e D é ainda mais acentuada pela presença dos genes envolvidos com a produção de biofilme. O potencial genético relacionado à adesão desses dois perfis difere 
apenas pela presença do gene icaA no clone $\mathrm{D}$ e ausente no $\mathrm{C}$, portador apenas de icaD. Esses genes fazem parte de um operon e codificam as principais proteínas envolvidas na formação do biofilme. Os genes ica foram pouco freqüentes entre os demais tipos clonais. Além dos isolados associados aos perfis C e D, apenas duas cepas originadas de insufladores e associadas ao perfil clonal E apresentaram o gene icaD. As cepas produtoras de biofilme têm maior capacidade de colonização quando comparadas com cepas não produtoras (VANCRAEYNEST et al., 2004).

Os perfis clonais C e D foram encontrados em fazendas distintas, mas localizadas no mesmo município e com alguns funcionários em comum. O perfil clonal $\mathrm{D}$, por ser um isolado de insuflador, pode ter origem humana e ser um indício de contaminação desse equipamento utilizado no processo de ordenha. Quanto ao perfil clonal C, a sua ocorrência em amostras de leite mastítico de nove animais diferentes de uma mesma fazenda pode sugerir uma fonte comum de infecção ou que a combinação dos fatores de virulência, característica desse perfil, constitui um genótipo freqüente entre os S. aureus isolados desses animais.

Ainda com relação à produção de biofilme, a ausência do gene bap - codificador de uma proteína associada a esse fator de virulência - entre as cepas analisadas condiz com as observações de VAUTOR et al (2008) que relataram baixa incidência desse gene em outras coleções de linhagens animais. Tem sido relatado que isolados animais preferencialmente carregam o gene bap em uma SaPI (TORMO et al., 2005), o que sugere ausência de transferência horizontal desse elemento genético entre as cepas deste estudo com outros portadores dessa ilha de patogenicidade. As cepas formadoras de biofilme analisadas aqui, caso expressem esse fenótipo, provavelmente utilizam o mecanismo regular dependente de PIA (polysaccharide intercellular adhesin), codificada pelo operon ica.

Em relação às duas cepas de $S$. aureus de mesmo perfil clonal provenientes de insufladores e obtidas em diferentes períodos de coleta, a análise da combinação dos fatores de virulência revelou, no primeiro isolado, apenas a presença do gene $c f l A$, enquanto o outro isolado obtido posteriormente apresentou também os genes icaD e eta, ao lado do cflA, o que pode sugerir o envolvimento desses genes com a persistência bacteriana.

Os genes clfA (proteína ligadora de fibrinogênio) e eno (proteína ligadora de laminina) foram os mais freqüentes entre os isolados deste trabalho. Quanto ao gene clfA, 
os resultados obtidos aqui assemelham-se às análises de KALOREY et al (2007) que revelaram a presença desse gene em 100\% dos isolados em uma investigação de determinantes de virulência de $S$. aureus provenientes de casos de mastite bovina subclínica. Em relação aos S. aureus provenientes de ovinos do presente estudo, também se observou a ocorrência do gene $c f l A$ em $100 \%$ dos isolados, sugerindo que a participação desse gene no processo de colonização e estabelecimento da mastite independe do tipo de hospedeiro. Associado ao gene $c f l A$, os perfis clonais de ovinos Q e R apresentaram, também, o genes $c f l B$ e icaD, respectivamente, e essas combinações foram identificadas tanto em isolados de mastite clínica quanto subclínica do mesmo perfil clonal.

A ausência do gene cna, codificador da proteína ligadora de colágeno, nos isolados deste trabalho está de acordo com SMELTZER et al (1997) que relataram que linhagens $S$. aureus animais geralmente não possuem esse gene. Em um estudo recente de caracterização e comparação genotípica de isolados S. aureus de amostras humanas, de mastite bovina subclínica e de alimentos (REINOSO et al., 2008), a detecção de cna foi somente efetuada para cinco linhagens humanas.

As combinações de exotoxinas estafilocócicas e a quantidade em que são secretadas podem definir o potencial patogênico da bactéria. A maioria das linhagens estafilocócicas bovinas produzem alfa e beta-hemolisinas (AARESTRUP et al., 1999) e algumas toxinas da família das leucocidinas (RAINARD et al., 2003). Essas exotoxinas formadoras de poros induzem trocas pré-inflamatórias em células de mamíferos, inativando o sistema imune por seu efeito citotóxico direto e degradando tecidos, o que provê, dessa forma, a bactéria com nutrientes facilitando a sua dispersão em novos sítios (PROJAN \& NOVICK 1997). Por atuar dessa forma, alguns autores sugerem que a alfa-toxina, codificada pelo gene hla, possa estar envolvida com mastite bovina gangrenosa (ANDERSON 1983), mas as relações entre essa toxina e a forma de manifestação clínica da doença continuam sendo debatidas.

Segundo uma pesquisa recente (HAVERI et al., 2008), os genes para as hemolisinas alfa, gama e beta foram encontrados em 97.4\%, 88.8\% e 76.7\%, respectivamente, em linhagens isoladas de casos de mastite bovina, sendo que $64,6 \%$ foram positivas para todas as hemolisinas. Ainda nessa pesquisa, um total de 43 combinações de genes de virulência 
foi observado, sendo a mais prevalente caracterizada pela associação de hla, hlb, hld, hlg e lukED. Os resultados do presente estudo diferem dos obtidos por HAVERI et al (2008) tanto em relação à alta freqüência dos genes codificadores das hemolisinas estafilocócicas entre os isolados como pela associação prevalente caracterizada por múltiplos genes de hemolisinas e leucotoxinas. A presença de lukED foi exclusiva para os isolados S. aureus provenientes das amostras de leite e de insufladores, sendo a associação desse gene com hla e hlb identificada apenas nos perfis clonais C e D. As linhagens originadas do óstio foram caracterizadas pela ausência desses genes.

A alta freqüência dos genes codificadores de hemolisinas pode indicar que os mesmos são essenciais para a patogênese de $S$. aureus em bovinos. No entanto, a produção de alfa ou beta-hemolisinas pode ser desnecessária para causar infecções intramamárias bovinas, pois linhagens sem esses genes têm sido encontradas nesse tipo de infecção (AKINEDEN et al., 2001) de acordo com parte dos resultados obtidos no presente estudo $53 \%$ dos isolados não apresentaram nenhum gene codificador dessas hemolisinas. Também não foram identificados portadores de hlg (gama-hemolisina), gene encontrado com muita freqüência em isolados de mastite bovina.

Um estudo mostrou que a beta-hemolisina foi produzida em $72 \%$ de isolados de mastite bovina, em $11 \%$ de isolados nasais de humanos saudáveis e em 13\% de isolados de casos de septicemia humana. $\mathrm{O}$ fato de a maioria das linhagens de $S$. aureus provenientes de bovinos carregarem o gene para a beta-hemolisina, em oposição às linhagens originadas de humanos (AARESTRUP et al., 1999), sugere que S. aureus beta-hemolítico pode ser mais patogênico ao gado do que a mesma espécie sem esta hemolisina, o que poderia aumentar a preocupação com os perfis clonais C e D - identificados neste estudo como os únicos portadores desse gene.

A distribuição do gene codificador da beta-hemolisina entre $S$. aureus provenientes de mastite bovina foi observada em 97\% das cepas analisadas (449 de 462) em um estudo (LARSEN et al., 2002) que envolveu isolados de nove países europeus e dos EUA. Essas cepas foram positivas na análise genotípica por PCR ou produziram beta-hemolisina em ágar sangue a 5\%, independente da variação geográfica. Com exceção de um pequeno número de $S$. aureus provenientes da Inglaterra, os isolados com resultados positivos por PCR expressaram a toxina em ágar sangue. Ao contrário e de forma curiosa, quase todos 
os isolados originados da Noruega foram negativos genotipicamente, mas apresentaram uma $\beta$-hemólise diferenciada em ágar sangue. Isso pôde ser explicado pela ocorrência de pequenas variações na seqüência do DNA de $S$. aureus $\beta$-hemolítico em áreas não detectadas pelos primers utilizados, como as que estão publicadas no GenBank (PROJAN et al., 1989; COLEMAN et al., 1991; KATEROV et al., 1994). Quanto aos isolados deste trabalho, a análise fenotípica da expressão de beta-hemolisina - positiva em quase 100\% das cepas - pode sugerir a existência de algumas dessas variações, uma vez que o gene hlb foi identificado somente em 33,3\% dos isolados S. aureus. Já com relação aos poucos isolados que foram negativos para a expressão da $\beta$-hemólise, podem ter perdido o gene ou a capacidade de expressá-lo ou, ainda, podem carregar uma variante desse gene que é insuficiente para a expressão da atividade $\beta$-hemolítica in vitro, como demonstrado por AARESTRUP et al (1999). Considerando a possibilidade de ocorrer variações na seqüência do gene $h l b$ e o fato de que a expressão da atividade hemolítica in vitro pode ser diferente da que ocorre in vivo, é difícil precisar o quanto os perfis clonais C e D são, de fato, mais preocupantes que os outros.

O processo de fagocitose por neutrófilos polimorfonucleados é considerado um dos mais importantes mecanismos de defesa da glândula mamária (CRAVEN et al., 1985). Por terem atuação sobre essas células, leucotoxinas bi-componentes têm uma importância significativa na patogênese de mastites estafilocócicas. Dados sobre a prevalência de leucotoxinas bi-componentes entre isolados de $S$. aureus provenientes de ruminantes com mastite são escassos, embora a identificação de linhagens causadoras dessa doença e portadoras dessas toxinas já ocorra há algum tempo (LOEFFLER et al., 1985).

Alguns estudos relatam que linhagens S. aureus causadoras de mastite são constituídas por algumas leucotoxinas, que todas possuem o gene hlg (gama-hemolisina), que a maioria é portadora dos genes para LukE-D e que entre 10 a 50\% carregam os genes para lukM-lukF'-PV (FUEYO et al., 2005 e PREVOST et al., 1999). De acordo com esses dados, POUTREL et al (dados não publicados e mencionados em RAINARD et al., 2003) detectaram, em uma coleção de $S$. aureus de ruminantes com mastite, que todos os isolados possuíam pelo menos os genes para gama-hemolisina e LukE-D. O presente estudo difere desses achados em relação à presença do gene hlg. Nenhum dos isolados analisados aqui apresentou o gene para a gama-hemolisina. Quanto à LukE-D, foi possível identificar a 
ocorrência dos genes para essa toxina em três perfis clonais distintos de S. aureus, o que corresponde a vinte isolados, pouco mais de 50\% do total, excluindo os demais coagulase positivos.

Considerando que as subunidades das classes $\mathrm{S}$ e $\mathrm{F}$ podem associar-se umas com as outras mesmo com atividades variadas e formar diferentes combinações ativas de leucotoxinas, pode-se sugerir que os perfis genéticos dos isolados de mastite identificados nesse estudo têm uma atuação menos complexa na patogênese da doença em relação às leucotoxinas bi-componentes, uma vez que não podem formar combinações heterólogas possuindo apenas os genes para LukE-D. Associações heterólogas poderiam aumentar o repertório de alvos celulares e conferir vantagem aos isolados portadores de mais de um gene de leucotoxinas (BARRIO et al., 2006).

Os genes para a leucotoxina PVL não foram identificados em nenhum dos isolados desse estudo, como esperado de certo modo, pois apenas $2 \%$ dos isolados clínicos humanos carregam os genes luk-PV e expressam essa toxina (BOHACH \& FOSTER, 2000). Considerando sua atuação em células de outros mamíferos, segundo esses mesmos autores, a PVL é ativa apenas em leucócitos de coelho, mas não em células de murídeos, ovinos ou cobaias. Foi mostrado que leucócitos humanos incubados com concentrações não citotóxicas de LukS-PV-LukF-PV são induzidos a secretar mediadores pré- inflamatórios como histamina e leucotrienes (KÖNIG et al., 1997). Todos esses mediadores são responsáveis por recrutar leucócitos para o sítio da infecção e então contribuir com o desenvolvimento da inflamação. Os efeitos de baixas concentrações de leucotoxinas em leucócitos bovinos, uma situação que pode ser mais freqüente durante a infecção do que a ocorrência de concentrações citotóxicas, ainda não é totalmente esclarecida (RAINARD et al., 2003).

Alguns estudos sugerem que as toxinas com atividade de superantígenos são importantes durante a patogênese da mastite devido aos seus efeitos imunomodulatórios (SCHUBERTH et al., 2001; FUEYO et al., 2005). A secreção dessas toxinas é considerada imunosupressiva, o que pode ser uma razão para a persistência de $S$. aureus no processo infeccioso (HAVERI et al., 2008). Pelo fato de S. aureus ser amplamente distribuído nos rebanhos leiteiros, a probabilidade de contaminação do leite cru por esse patógeno com conseqüente produção de enterotoxinas é bastante elevada. Em bovinos, KENNY et al 
(1993) relataram que no mínimo $28,6 \%$ das cepas isoladas do úbere secretavam uma ou mais toxinas. MATSUNAGA et al (1993), em outro estudo realizado no mesmo ano, encontraram $34,5 \%$ de cepas enterotoxigênicas. No entanto, em estudo realizado por SÁ et al (2004), de determinação da ocorrência de $S$. aureus enterotoxigênico em amostras de leite provenientes de animais com mastite subclínica, os autores observaram menor ocorrência dessas cepas, apenas 4,39\% dos isolados expressaram os genes codificadores de enterotoxinas. A ausência dos genes para as enterotoxinas A-E, característica das cepas isoladas de óstios e leite bovinos e de insufladores analisadas no presente estudo, indica que a ocorrência dessas linhagens no leite apresenta menos riscos de intoxicação alimentar, especialmente pela ausência do gene sec, uma vez que a EEC é a mais termoestável das enterotoxinas, seguida pelas EEB e EEA.

Quanto à enterotoxina $\mathrm{A}, \mathrm{o}$ fato de nenhum isolado deste estudo ter apresentado o gene sea condiz com as observações de KALOREY et al (2007) em uma pesquisa recente que analisou os determinantes dos fatores de virulência de isolados $S$. aureus provenientes de casos de mastite bovina subclínica. Entretanto, esses resultados diferem da ocorrência descrita por outros pesquisadores (AKINEDEN et al., 2001; STEPHAN et al., 2001) em estudos da mesma natureza. Os genes sea e seb são raros em isolados S. aureus bovinos, mas têm sido encontrados em cepas associadas com alimentos contaminados de humanos (CHEN et al., 2004). Esses genes também foram pouco freqüentes entre os isolados analisados por HAVERI et al (2008) que identificaram como prevalentes para PTSAg os genes do grupo egc (seg, sei, sem, sen e seo), não incluídos no presente estudo. A capacidade das cepas analisadas aqui de causar intoxicação alimentar não está totalmente excluída, pode estar associada à produção de outras enterotoxinas não pesquisadas.

A ausência do gene sed exclui a possibilidade da ocorrência de um suposto plasmídio que carrega os genes sed e sej concomitantemente com o gene de resistência à penicilina (blaZ). A resistência a esse antibiótico, apresentada por aproximadamente 100\% dos isolados provenientes de bovinos, não está associada a esse elemento genético móvel que, por sua vez, é predominante em linhagens persistentes em infecções intramamárias bovinas (ZHANG et al., 1998).

Nossos resultados assemelham-se, com exceção da ocorrência do gene eta, com os de um estudo recente (HERRON-OLSON et al., 2007) no qual os genes see, eta e etb não 
foram detectados entre as linhagens. Os genes eta e etb, codificadores de toxinas esfoliativas associadas com a síndrome da pele escaldada humana, também não foram detectados em HAVERI et al (2008) e LARSEN et al (2000). Linhagens portadoras desses genes provenientes de glândulas mamárias bovinas podem indicar origem humana de infecção. Entre os nossos isolados, o gene eta foi identificado em quatro cepas de $S$. aureus, sendo uma proveniente de óstio bovino e três de insufladores, sugerindo a participação humana em uma possível transmissão. Duas dessas cepas isoladas de insufladores apresentaram o mesmo perfil clonal.

Com relação ao gene tst, nossos resultados foram negativos para todos os isolados originados de óstios bovinos, do leite mastítico desses animais e de insufladores, ao contrário de alguns estudos, como o de CARDOSO et al (2000) que mostrou que 43\% dos S. aureus isolados de casos clínicos e subclínicos de mastite bovina produziram TSST-1.

A comum ocorrência dos genes que codificam toxinas de superantígenos em alguns estudos (KATSUDA et al., 2005; ZSCHÖCK et al., 2005) pode indicar, segundo esses autores, que os genes codificadores dessas toxinas são favoráveis para a estabilização de $S$. aureus em infecções intramamárias bovinas. Essas toxinas podem ajudar na dispersão da bactéria dentro de um hospedeiro e até entre hospedeiros, uma vez que são secretadas em períodos de alta densidade bacteriana, no caso, na fase pós- exponencial do crescimento. A ocorrência dos genes codificadores dessas toxinas está sendo associada a casos de infecções intramamárias persistentes. Em pesquisa recente, HAVERI et al (2008) mostraram que esses genes estavam presentes em $80 \%$ dos isolados obtidos desse tipo de infecção em oposição aos 63,9\% daqueles provenientes de infecções intramamárias não persistentes. A análise do conteúdo genético das cepas do presente estudo permite inferir que as mesmas não estão envolvidas com possíveis casos de reincidência da mastite, pelo menos no que diz respeito às toxinas de superantígenos pesquisadas aqui.

Os isolados S. aureus provenientes de ovinos apresentaram maior diversidade na combinação dos genes de virulência relacionados à produção de exotoxinas. Ao redor de $55,5 \%$ do total de isolados S. aureus, pertencentes às linhagens $\mathrm{P}$ e Q, apresentaram, além de genes codificadores de adesinas relacionados à produção de biofilme, genes responsáveis pela produção de citotoxinas e toxinas com atividade de superantígenos, o que pode explicar altos índices de morbidade ou letalidade observados em alguns casos de 
ovinos acometidos por mastites causadas por esta bactéria. Quase todos os genes codificadores de toxinas de superantígeno estão relacionados com ilhas de patogenicidade ou outros elementos genéticos, alguns desses coexistindo no mesmo isolado. A associação dos genes tst e sec, identificada nos isolados de mastite subclínica com o perfil clonal Q, pode sugerir que essas linhagens sejam portadoras de SaPIbov1. A freqüência dessa associação neste estudo, 16,6\%, foi inferior às observações de ORDEN et al (1992b) que a encontraram em $74 \%$ dos isolados originados de ovinos. O perfil clonal $\mathrm{P}$ também foi portador do gene sec, mas não associado com tst e, como no caso do perfil clonal Q, esse gene foi identificado apenas nos isolados provenientes de mastite subclínica. Apesar do quadro clínico mais severo da mastite clínica, os isolados com perfil clonal $\mathrm{P}$ ou $\mathrm{Q}$, provenientes de animais portadores dessa forma da doença, preocupam menos que os isolados com os mesmos perfis clonais originados de mastite subclínica, pois esses carregam o gene da enterotoxina mais termoestável, a EEC. A ocorrência de sec correspondeu a $44,4 \%$ do total de isolados provenientes de ovinos sendo o único gene codificador de enterotoxina encontrado neste estudo. Esses resultados são condizentes com a prevalência desse gene em animais da mesma espécie observada por ORDEN et al (1992a).

A ocorrência do gene tst entre os isolados provenientes de ovinos deste estudo, ao contrário do gene sec, foi observada tanto nas linhagens isoladas de mastite clínica como subclínica, correspondendo a $11,1 \%$ e 16,6\%, respectivamente. A capacidade de produzir TSST-1 das linhagens estafilocócicas isoladas de diferentes sítios anatômicos de ovinos saudáveis e a detecção de anticorpos para essa toxina no leite e no soro foram estudadas por VALLE et al (1991) e podem sugerir um contato freqüente desses animais com linhagens produtoras dessa toxina.

Considerando um mesmo perfil clonal originado de ovinos, exceto o perfil R, observou-se maior combinação dos genes codificadores de exotoxinas nos isolados provenientes de mastite subclínica e não nos originados de mastite clínica. Outros fatores de virulência não pesquisados neste estudo podem compor o conteúdo genético dos isolados provenientes da forma mais severa da doença. 
Vários sistemas reguladores, agr, sar, sigB, sae, arl e seis homólogos SarA estão envolvidos com a expressão dos genes determinantes dos fatores de virulência de $S$. aureus. A atuação do locus agr é considerada significativa na patogênese dessa espécie em vários modelos de infecção animal, mas a expressão de determinados genes depende do controle de diferentes sistemas reguladores, o que torna complexo definir o papel de agr nas infecções estafilocócicas. O locus agr tem um envolvimento essencial na regulação positiva da expressão dos genes de exoproteínas, enquanto regula negativamente a síntese de adesinas de superfície celular durante a transição da fase exponencial para pós-exponencial (CHEUNG et al., 2004). No entanto, YARWOOD et al (2002) demonstraram que a expressão de agr não é necessária para o desenvolvimento da síndrome do choque tóxico, o que acentua o aspecto multifatorial da virulência de $S$. aureus. A expressão de determinados genes de toxinas está relacionada a grupos agr específicos, porém este estudo se limitou à pesquisa de possíveis relações entre as combinações de fatores de virulência apresentados por isolados animais e seu grupo agr.

Em relação ao sistema de regulação global agr dos isolados $S$. aureus provenientes de bovinos, foi possível identificar as cepas com perfis clonais C e D como portadoras do grupo II. Esses dois perfis clonais foram os únicos a apresentar pelo menos $50 \%$ dos genes codificadores dos fatores de virulência pesquisados neste estudo, o que pode sugerir uma relação entre o grupo II de agr e a presença de múltiplos fatores de virulência em linhagens bovinas de S. aureus. Já o grupo III de agr foi identificado em apenas dois isolados - um proveniente do óstio e outro de leite mastítico - portadores de apenas um gene codificador de adesina, o clfA. Essas cepas não tiveram um perfil clonal definido por PFGE. Os demais isolados não foram identificados como os grupos I, II, III ou IV de agr, sendo classificados, portanto, como agr negativos e corresponderam a $60 \%$ dos isolados $S$. aureus provenientes de bovinos e insufladores. O agr negativo não pôde ser relacionado com a quantidade ou com a natureza dos genes codificadores dos fatores de virulência, uma vez que essa característica não foi exclusiva de isolados portadores de poucos desses genes e nem daqueles com combinações mais variadas. A associação do agr negativo também não pôde ser feita com a procedência das amostras, uma vez que essa característica apareceu em pelo menos um isolado proveniente de cada local de coleta. 
A presença do gene eta foi identificada em três isolados agr negativos e em um do grupo II, diferente da forte associação desse gene com o grupo IV observada em isolados $S$. aureus de humanos.

A distribuição neste estudo dos grupos de agr entre os isolados bovinos foi de $33,3 \%$ do grupo II, $6,6 \%$ do grupo III e $60 \%$ de agr negativos. Esses resultados diferem dos obtidos por GILOT \& LEEUWEN (2004) em uma pesquisa em que compararam a diversidade genética desse locus regulador em isolados $S$. aureus de mastite bovina e de humanos. Esses pesquisadores identificaram maior freqüência do grupo I entre as linhagens bovinas (69\%), seguida dos grupos II, III e IV correspondendo a 23,9\%, 2,8\% e 1,4\% dos isolados, respectivamente. A prevalência do grupo I, ao contrário dos resultados obtidos neste trabalho, também foi relatada por BUZZOLA et al (2006) em um estudo que associou esse grupo de agr à persistência das linhagens $S$. aureus em tecidos da glândula mamária.

Entre as linhagens de $S$. aureus provenientes de ovinos, observou-se uma ocorrência equilibrada dos grupos I e II de agr e esses grupos foram associados tanto aos isolados de mastite clínica como subclínica. Nenhum portador dos grupos III e IV ou arg negativos foram encontrados nas amostras ovinas deste estudo, resultados que diferem de uma pesquisa recente (VAUTOR et al., 2008) que identificou um clone predominante somente encontrado em ovinos e caprinos associado principalmente ao grupo III de agr. Assim como nos isolados bovinos, o grupo II de agr foi relacionado ao perfil que apresentou maior combinação dos fatores de virulência, incluindo a associação dos genes sec e tst, porém esse grupo também foi identificado em isolados portadores de apenas um gene codificador de adesina e de nenhum para exotoxinas, o que coloca em questão sua relação com a presença de múltiplos fatores de virulência em linhagens ovinas. Da mesma forma, o grupo I de agr foi encontrado tanto em linhagens que carregavam uma combinação diversificada dos genes determinantes de virulência como em linhagens portadoras de poucos desses genes.

Em relação aos perfis de resistência das cepas analisadas, observou-se maior sensibilidade a diferentes antimicrobianos entre os isolados ovinos. O perfil 1 , definido neste estudo como sensível às categorias dos antibióticos testados, correspondeu a 22,8\% e $100 \%$ dos isolados bovinos e ovinos, respectivamente. Recentemente, foi descrito um 
sistema em S. aureus que controla as transferências dos elementos genéticos móveis entre isolados de diferentes linhagens (WALDRON \& LINDSAY, 2006) podendo ser uma explicação para a ocorrência dos perfis caracterizados por alta sensibilidade aos antimicrobianos. Esse sistema, denominado Saul ou SauI, codifica uma enzima de restrição que reconhece um DNA externo e o digere, reduzindo a freqüência de transferência horizontal dos elementos genéticos móveis. A especificidade desse sistema, determinada pelos genes sau1hsdS1 e sau1hsdS2, limita as trocas de DNA, prevenindo a transferência de genes de resistência entre linhagens animais e contribuindo para a evolução independente de cada uma delas (SUNG et al., 2008).

$\mathrm{O}$ perfil 2, caracterizado apenas por resistência à penicilina e ampicilina, foi identificado em $26,6 \%$ dos isolados bovinos. A resistência à penicilina em $S$. aureus tem sido associada com mastite crônica (SOL et al., 2000; TAPONEM et al., 2003), apesar da presença de linhagens bovinas portadoras do gene blaZ não explicar totalmente a persistência das infecções. A resposta dessas linhagens ao tratamento varia entre diferentes tipos clonais (HAVERI et al., 2008).

Os isolados resistentes à oxacilina corresponderam a 50,6\% dos isolados bovinos. Essa alta taxa de resistência deve-se, possivelmente, à maneira como a amostragem foi constituída. Foram incluídas neste estudo amostras coletadas em um período em que se praticava o uso da associação de ampicilina e cloxacilina sódica no tratamento preventino de mastite bovina em uma das fazendas.

O alto nível de resistência à oxacilina é sempre dependente da expressão de uma proteína alterada no genoma bacteriano, denominada PBP2a, que possui baixa afinidade para a maioria dos antibióticos beta-lactâmicos e é codificada pelo gene mecA. A concentração inibitória mínima de oxacilina entre 1 e $8 \mu \mathrm{g} / \mathrm{mL}$ e a ausência do gene mecA indicam que essas cepas desenvolvem outro mecanismo de resistência aos antibióticos betalactâmicos, caracterizando-se por uma sensibilidade denominada limítrofe ou borderline.

Apesar da ausência do gene mecA ser relatada em alguns estudos como o de HAVERI et al (2008) que pesquisaram os genes codificadores dos fatores de virulência de S. aureus isolados de infecções intramamárias bovinas persistentes e não persistentes, poucos são os dados publicados sobre a relação do fenótipo BORSA e os casos de mastites bovina e ovina. No entanto, em um estudo recente de caso clínico humano (SKINNER, S. 
et al., 2009), a análise de PFGE de um isolado BORSA proveniente de um paciente com endocardite e de outros isolados sensíveis de culturas anteriores do mesmo paciente mostrou que esses eram clones idênticos, o que indica o desenvolvimento de resistência devido, provavelmente, a mutações na mesma linhagem e não resultado de novas infecções. Isso reforça a preocupação com séries múltiplas e inadequadas de terapias com betalactâmicos que levam ao desenvolvimento do fenótipo BORSA e a seleção dessas linhagens. A associação de um beta-lactâmico com um inibidor de beta-lactamase é eficaz apenas quando o mecanismo de hiper-produção de beta-lactamase é o único responsável pelo fenótipo BORSA. Isolados com possíveis mutações na PBP não respondem a esse tratamento.

Embora as linhagens BORSA sejam definidas como mecA negativas com CIM de oxacilina entre 1 e $8 \mu \mathrm{g} / \mathrm{ml}$, alguns isolados negativos para esse gene com CIM de 12 e $16 \mu \mathrm{g} / \mathrm{ml}$ por determinação de E-test foram encontrados nessa pesquisa. O isolado BORSA do caso clínico de SKINNER, S. et al (2009) também apresentou $12 \mu \mathrm{g} / \mathrm{ml}$ de concentração inibitória mínima para a oxacilina.

O fenótipo BORSA apresentado pelas cepas deste estudo não foi associado a perfis clonais específicos assim como na pesquisa de NADARAJAH et al (2006). Esses autores também mostraram que a prevalência de uma linhagem, a ST25 de S. aureus, como colonizadora de bovinos, pode estar relacionada à propensão de adquirir substituições na PBP2 e aos cuidados com rebanhos leiteiros (CHRIEL \& DIETZ, 2003). O tratamento com antibióticos em períodos "secos" ou fora da lactação como profilaxia para a prevenção da incidência de mastite em futuras lactações pode selecionar linhagens BORSA como colonizadores predominantes de gados leiteiros e promover reservatórios estáveis para a manutenção dessas linhagens e sua transmissão para humanos. 


\section{Conclusões}

- Houve alta diversidade genética entre as linhagens de $S$. aureus isoladas das diferentes fontes analisadas das três fazendas de exploração leiteira pertencentes ao Estado de SP.

- Os isolados S. aureus provenientes de ovinos do Município de Garanhuns do Estado de PE mostraram baixa diversidade genética com três perfis clonais comuns aos casos de mastites clínica e subclínica.

- S. aureus originados dos óstios bovinos, independente do perfil clonal, caracterizaram-se pela pouca ocorrência dos genes relacionados ao processo toxigênico, com exceção de uma cepa portadora do gene eta, codificador da toxina esfoliativa.

- Dois perfis clonais de S. aureus - um associado a isolados de leite mastítico bovino e outro a um isolado obtido de insuflador - apresentaram maior combinação dos fatores de virulência, caracterizando-se pela presença dos genes codificadores das proteínas que se ligam ao fibrinogênio, fibronectina, laminina, dos genes relacionados à adesão intercelular e pela associação de lukED com hla e hlb.

- A maioria das linhagens de $S$. aureus provenientes de ovinos foi portadora de genes de hemolisinas e lukED e metade apresentou pelo menos um gene para toxina de superantígeno. A ocorrência da associação dos genes sec (enterotoxina C) e tst (toxina da síndrome do choque tóxico - TSST-1) foi exclusiva dessas cepas.

- O grupo II do sistema regulador agr foi associado aos perfis clonais das linhagens bovinas e ovinas que apresentaram maior combinação dos fatores de virulência, mas também foi identificado em cepas portadoras de poucos genes de adesinas e exotoxinas provenientes de amostras ovinas. O mesmo foi observado para as linhagens do grupo I de agr, identificadas apenas em amostras ovinas. 
- O grupo III e agr negativos foram exclusivos dos isolados de leite e óstios bovinos e de insufladores portadores de poucos genes codificadores dos fatores de virulência.

- Observou-se isolados de leite de vacas com mastite subclínica com total sensibilidade aos diferentes antimicrobianos testados - assim como todas as cepas originadas de ovinos - e com perfil de resistência à penicilina e ampicilina.

- As cepas resistentes à oxacilina (BORSA), provenientes de óstios bovinos e de insufladores, apresentaram concentração inibitória mínima $\geq 1$ - $\leq 16 \mu \mathrm{g} / \mathrm{ml} \mathrm{com}$ múltipla resistência a outros antimicrobianos, mas foram negativas para o gene mecA. 


\section{Referências bibliográficas}

AARESTRUP, F.M. Association between the consumption of antimicrobial agents in animal husbandry and the occurrence of resistant bacteria among food animals. International Journal of Antimicrobial Agents, Amsterdam, v. 12, p. 279-285, 1999.

AKINEDEN, G., ANNEMULLER, C, HASSAN, A.A., LAMMLER, C, WOKER, W. \& ZSCHOCK, M. Toxin genes and other characteristics of Staphylococcus aureus isolates from milk of cows with mastitis. Clin Diagn Lab Immunol. 8,959-964, 2001.

ANDERSON, J.C. Veterinary aspects of staphylococci. In Staphylococci and Staphylococcal infections, ed. Easmon, C.S.F. and Adlam, C. v. 1, p. 193-241. London: Academic Press, 1983.

ANDERSON, D.E.; HULL, B.L.; PUGH, D.G. Enfermidades da glândula mamária. In:PUGH, D. G. Clínica de ovinos e caprinos. São Paulo: Roca, p. 513, 2005.

ARRIZUBIETA M.J., TOLEDO-ARANA A., AMORENA B., PENADÉS J.R. AND LASA I. Calcium Inhibits Bap-Dependent Multicellular Behavior in Staphylococcus aureus. Journal of Bacteriology, November. p. 7490-7498, v. 186, nº. 22, 2004.

BALABAN, N. \& RASOOLY, A. Staphylococcal enterotoxins. In J Food Microbiol 61, 1-10, 2000.

BANNERMAN, T.L. Staphylococcus, Micrococcus, and other catalase-positive cocci that grow aerobically. In: MURRAY, P.R et al. (Eds.). Manual of clinical microbiology. Washington: American Society for Microbiology, p. 384-404, 2003.

BANNERMAN, D,D.; PAAPE, M.J.; LEE, J.W.; ZHAO, X.; HOPE, J.C.; RAINARD, P. Escherichia coli and Staphylococcus aureus elicit differential innate immune responses following intramammary infection. Clin Diagn Lab Immunol. May;11(3):463-72, 2004.

BARG, N. \& MCMURRAY, L.W. Characterization of a novel $\beta$-lactamase plasmid widely distributed amomg borderline oxacillin-susceptible strains of Staphylococcus aureus. In: Novick, R. P. (Ed.), Molecular Biology of the Staphylococci. VCH Publishers, New York, NY, USA, p. 623-625, 1990.

BARG, N.; CHAMBERS H.; KERNODLE, D. Borderline susceptibility to antistaphylococcal penicillins is not conferred exclusively by the hyperproduction of beta-lactamase. Antimicrob Agents Chemother. Oct;35(10):1975-9, 1991.

BARRIO M.B.; RAINARD P.; PREVOST G. LukM/LukF'-PV is the most active Staphylococcus aureus leukotoxin on bovine neutrophils. Microbes Infect ft: 2068-2074, 2006.

BECKER, K.; EIFF, C.; KELLER, B.; BRÜCK, M.; ETIENNE, J.; PETERS, G. Thermonuclease gene as a target for specific identification of Staphylococcus intermedius isolates: use of a PCR-DNA enzyme immunoassay. Diagnostic Microbiology and Infectious Disease. 51: 237-244, 2005. 
BELKUM, V.A.; MELLES, D.C.; PEETERS, J.K.; VAN LEEUWEN, W.B.; VAN DUIJKEREN, E.; HUIJSDENS, X.W.; SPALBURG E.; DE NEELING, A.J.; VERBRUGH, H.A.MethicillinResistant and Susceptible Staphylococcus aureus Sequence Type 398 in Pigs and Humans, 2008.

BENNETT R.W; MONDAY, S.R. Staphylococcus aureus. In: MILLIOTIS, M.D.; BIER, J.W. (Eds). Internation Handbook of Foodborn Pathogens. New York: Marcel Dekker, Inc., cap. 4, p. 4159, 2003.

BENNETT R.W, NOTERMANS S.; TATINI S.R. Staphylococcal enterotoxins. In: VANDERZANT, C; SPLITTSTOESSA, D.F. (Eds). Compendium of methods for the microbiological examination of foods.Washington (DC): American Public Health Association. p.551-592, 1999.

BENS C.P.M.; VOSS A.; KLAASSEN C.H.W. Presence of a novel DNA methylation enzyme in methcillin-resistant Staphylococcus aureus isolates associate with pig farming leads to uninterpretable results in standard pulsed-field gel electrophoresis analysis. J Clin Microbiol. 44: 1875-1876, 2006.

BERGDOLL, M.S. Staphylococcus aureus. In: Doyle, M. P. (Ed.) Foodborne bacterial pathogens. New York: M. Dekker. p. 463-523, 1989.

BHAKDI, S. \& TRANUM-JENSEN, J. Alpha-toxin of Staphylococcus aureus. Microbiol. Rev. 55:733-751, 1991.

BLAGITZ, M.G. Avaliação da relação do exame físico da glândula mamária de ovelhas da raca Santa Inês com o perfil citológico e bacteriológico do leite. 195f. Dissertação (Mestrado em Clínica Veterinária) - Faculdade de Medicina Veterinária e Zootecnia, Universidade de São Paulo, 2007.

BLOOD, D.C.; RADOSTITS, O.M. Veterinary Medicine. London: Baillière Tindall. p.501-59: Mastitis. 7.ed, 1991.

BOHACH, G.A., DINGES, M.M.; MITCHELL, D.T.; OHLENDORF, D.H. \& SCHLIEVERT, P.M. Exotoxins, p.83-111. In K.B. Crossley and G.L. Archer. (ed.) The staphylococci in human disease. Churchill Livingstone, New York, N.Y, 1997.

BOHACH, G.A.; FOSTER, T.J. S. aureus exotoxins In: FISCHETTI, V.A. et al Gram-Positive Pathogens. American Society for Microbiology. p. 367-378, 2000.

BOYSO, J.; CARDOSO-CORREA, B.I.; CAJERO-JUÁREZ, M.; BRAVO-PATIÑO, A.; VALDEZ-ALARCÓN, J.J.; BAIZABAL-AGUIRRE, V.M. The capacity of bovine endothelial cells to eliminate intracellular Staphylococcus aureus and Staphylococcus epidermidis is increased by the proinflammatory cytokines TNF-alpha and IL-1beta. FEMS Immunol Med Microbiol. Oct;54(1):53-9, 2008. Epub 2008 Jul 9.

BRAMLEY, A.J.; DODD, F.H. Reviews of the progress of dairy science: mastitis control: progress and prospects. Journal of Dairy Research, London, v. 51, p. 481-512, 1984. 
BROUILLETTE E.; TALBOT B.G.; MALOUIN F. The fibronectin-binding proteins of Staphylococcus aureus may promote mammary gland colonization in a lactating mouse model of mastitis. Infect Immun. Apr;71(4):2292-5, 2003.

BUTLER, J.E. Immunoglobulins and immunocytes in animal milks. In: OGRA, P. L.; MESTECKY J.; LAMM, M. E.; STROBER, W.; BIENESTOCK, J.; MCGHEE, J. R. (Ed.). Mucosal immunology. New York: Academic Press, p. 1531-1554, 1999.

BUZZOLA, F.R.; BARBAGELATA, M.S.; CACCURI, R.L.; SORDELLI, D.O. Attenuation and persistence of and ability to induce protective immunity to a Staphylococcus aureus aroA mutant in mice. Infect Immun. Jun;74(6):3498-506, 2006.

CARDOSO, H.F.T; CARMO, L.S.; SILVA, N. Detecção da toxina-1 da síndrome do choque tóxico em amostras de Staphylococcus aureus isoladas de mastite bovina. Arq. Bras. Med. Vet. Zootec, v. 52, n.1, p. 7-10, 2000.

CARVALHO, L.B. Padrão de infecção intramamária em búfalas (Bubalus bubalis) da região do Alto São Francisco, MG. 37f. Dissertação (Mestrado em Medicina Veterinária) - Escola de Veterinária, Universidade Federal de Minas Gerais, Belo Horizonte, 2005.

CHAMBERS, H.F.; ARCHER, G.; MATSUHASHI, M. Low-level methicillin resistance in strains of Staphylococcus aureus. Antimicrob Agents Chemother. Apr;33(4):424-8, 1989.

CHAMBERS, H.F. Methicillin-resistance in Staphylococci: molecular and biochemical basis and clinical implications. Clin. Microbiol. Rev.10:781-791, 1997.

CHEN, T.R., CHIOU, C.S. \& TSEN, H.Y. Use of novel PCR primers specific to the genes of staphylococcal enterotoxin G, H, I for the survey of Staphylococcus aureus strains isolated from foodpoisoning cases and food samples in Taiwan. Int J Food Microbiol 92,189-197, 2004.

CHEUNG, A.L.; BAYER, A.S.; ZHANG, G.; GRESHAM, H.; XIONG, Y.Q. Regulation of virulence determinants in vitro and in vivo in Staphylococcus aureus. FEMS Immunol Med Microbiol. 40:1-9, 2004.

CHRIEL, M. \& DIETZ, H.H. Medication of production animals - cure of malfunctioning animals or production systems? Acta Vet Scand 98, 65-70, 2003.

CLEMENTS, A.C.A.; TAYLOR, D.J.; FITZPATRICK, J.L. Evaluation of diagnostic procedures for subclinical masitits in meat-producing sheep. Journal of Dairy Research, v. 70, p. $139-148,2003$.

CLSI. Performance Standards for Antimicrobial Susceptibility Testing. M100-S11, v. 21, n 1. January, 2007.

COLEMAN, D.C., ARBUTHNOTT, J.P.; POMEROY, H.M.; BIRKBECK, T.H. Cloning and expression in Escherichia coli and Staphylococcus aureus of the ß-lysin determinant from Staphylococcus aureus: evidence that bacteriophage conversion of $\beta$-lysin activity is caused by insertional inactivation of the ß-lysin determinant. Microb. Pathog. 1:549-564, 1986. 
COLEMAN, D., KNIGHTS, J., RUSSELL, R., SHANLEY, D., BIRKBECK, T.H., DOUGAN, G., CHARLES, I. Insertional inactivation of the Staphylococcus aureus beta-toxin by bacteriophage phi 13 occurs by site- and orientation-specific integration of the phi 13 genome. Mol. Microbiol. 5, 933-939, 1991.

CONTRERAS, A.; SIERRA, D.; SÁNCHEZ, A.; CORRALES, J.C.; MARCO, J.C.; PAAPE, M.J.; GONZALO, C. Mastitis in small ruminants. Small Ruminant Research, 68: 145-153, 2007.

COONEY, J.; KIENLE, Z.; FOSTER, T.J.; O'TOOLE, P.W. The gama hemolysin locus of Staphylococcus aureus comprises three linked genes, two of which are identical to the genes form $\mathrm{F}$ and $\mathrm{S}$ components of leucocidin. Infect Immun. v. 61, p. 768, 1993.

COSTA, E.O.; VIANI, F.C.; WHITE, C. R.; ABE, S.; LOPES, V.C.A. Importância do portador na dinâmica da infecção intramamária. In: Congresso brasileiro de Medicina Veterinária, Olinda. Anais. SBMV, p. 239, 1994.

COSTA, E.O. Importância da mastite na produção leiteira do Brasil. Revista de Educação Continuada do CRMV-SP, São Paulo, v. 1, p. 3-9, 1998.

COSTA, E. O. Leite, problema cultural. Revista NAPGAMA, Pirassununga, v. 2. n.4, p.2, 1999.

CRAVEN, N., \& M.R. WILLIAMS. Defences of the bovine mammary gland against infection and prospects for their enhancement. Vet. Immunol. Immunopathol. 10:71-127, 1985.

CUCARELLA, C.; SOLANO, C.; VALLE, J.; AMORENA, B.; LASA, I.; PENADÉS, J.R. BAP, A Staphylococcus aureus surface protein involved in biofilm formation. $\mathbf{J}$ Bacteriol. May;183(9):2888-96, 2001.

CUCARELLA, C.; TORMO, M.A.; KNECHT, E.; AMORENA, B.; LASA, I.; FOSTER, T.J.; PENADÉS, J.R. Expression of the biofilm-associated protein interferes with host protein receptors of Staphylococcus aureus and alters the infective process. Infect Immun. Jun;70(6):3180-6, 2002.

CUCARELLA, C.; TORMO, M.A.; UBEDA, C.; TROTONDA, M.P.; MONZÓN, M.; PERIS C.; AMORENA, B.; LASA, I.; PENADÉS, JR. Role of film-associated protein bap in the pathogenesis of bovine Staphylococcus aureus. Infect Immun. 72:2177-2185, 2004.

CUNHA, M.L.R.S. Anais do IV encontro de pesquisadores em mastites. FMVZ-UNESP. Botucatu-SP, p. 56-63, 2007.

DAO-PIN, S., ANDERSON, D.E.; BAASE, W.A.; DAHLQUIST, F.W.; MATTHEWS, B.W. Structural and thermodynamic consequences of burying a charged residue within the hydrophobic core of T4 lysozyme. Biochemistry 30:11521-11529, 1991.

DZIEWANOWSKA, K.; PATTI, J.M.; DEOBALD, C.F.; BAYLES, K.W.; TNIMBLE, W.R. \& BOHACH, G.A. Fibronectin binding protein and host cell tyrosine kinase are required for internalization of Staphylococcus aureus by epithelial cells. Infect. Immun. 67:4673-4678, 1999.

EUSÉBY (J.P.): List of Bacterial Names with Standing in Nomenclature: a folder available on the Internet. Int. J. Syst. Bacteriol., 1997, 47, 47, 590-592. (List of Prokaryotic Names with Standing in Nomenclature. Last full update March 02, 2007. URL:(http://www.bacterio.net) 
FAGUNDES, H.; OLIVEIRA, C.A.F. Infeccoes intramamarias causadas por Staphylococcus aureus e suas implicacoes em saude publica. Ciencia Rural, v. 34, n.4, p. 1315-1320, 2004.

FERRERAS, M.; HÖPER, F.; DALLA SERRA, M.; COLIN, D.A.; PREVOST, G.; MENESTRINA, G. The interaction of Staphylococcus aureus bi-component gamma-hemolysins and leucocidins with cells and lipid membranes. Biochim Biophys Acta. Nov 11;1414(1-2):108-26, 1998.

FITZGERALD, I.K.; HARTIGAN, P.J.; MEANEY, W.J.; SMYTH, C.J. Molecular population and virulence factor analysis of Staphylococcus aureus from bovine intramammary infection. , J Appl Microbiol, 88, 1028-1037, 2000.

FITZGERALD, J.R.; STURDEVANT, D.E., MACKIE, S.M.; OIL, S.R., MUSSER J.M. Evolutionary genomics of Staphylococcus aureus: insights into the origin of methicillin-resistant strains and the toxic shock syndrome epidemic. Proc Natl Acad Sci USA 98: 0021-8826, 2001.

FLOCK, J.I.; HIENZ, S.A.; HEIMDAHL, A.; SCBENNINGS, T. Reconsideration of the role of fibronectin binding in endocarditis caused by Staphylococcus aureus. Infect. Immun. 64:1876$1878,1996$.

FOX, L.K.; GERSHMAN, M.; HANCOCK, D.D.; HUTTON, C.T. Fomites and reservoirs of Staphylococcus aureus causing intramammary infections as determined by phage typing: the effect of milking time and hygiene practices. Cornell Veterinarian, Ithaca, n. 81, p. 183-193, 1991.

FUEYO, J.M.; MENDOZA, M.C.; ALVAREZ, M.A.; MARTÍN, M.C. Relationships between toxin gene content and genetic background in nasal carried isolates of Staphylococcus aureus from Asturias, Spain. FEMS Microbiology Letters, Amsterdam v. 243, p. 447-454, 2005

GÁL, Z.; KOVÁCS, P.; HERNÁDI, F.; BARABÁS, G.; KISS, L.; IGLÓI, A.; SZABÓ I. Investigation of oxacillin-hydrolyzing beta-lactamase in borderline methicillin-resistant clinical isolates of Staphylococcus aureus. Jul-Aug;47(4):233-8, 2001.

GARRITY, G.M. Bergey's Manual of Systematic Bacteriology 2nd Edition: v. 3: The low G+C Gram positives. Springer-Verlag, New York. ISBN 0-387-95041-9, 2006.

GILOT, P.; UNA, G.; COCFAARD, T.; POUTREL, B. Analysis of the genetic variability of genes encoding the RNA Ill-activating components Agr and TRAP in a population of Staphylococcus aureus strains isolated from cows with mastitis. J. Clin. Microbiol. 40:4060-4067, 2002.

GILOT, P. \& LEEUWEN, W. Comparative analysis of agr locus diversification and overall genetic variability among bovine and human Staphylococcus aureus isolates. J. Clinical Microbiology, Mar. p. 1265-1269, 2004.

GRAVET, A., COLIN, D.A.; KElleR, D.; GIRADOT, R.; MONTEIL, H.; PREVOST, G. Characterization of a novel structural member, LukE-LukD, of the bi-component staphylococcal leucotoxins family. FEBS Lett. 436:202-208, 1998. 
GRAVET, M.; RONDEAU, C.; HARF-MONTEIL, F.; GRUNENBERGER, H.; MONTEIL, J.; SCHEFTEL, M.; PREVOST., G. Predominant Staphylococcus aureus isolated from antibioticassociated diarrhea is clinically relevant and produces enterotoxin A and the bicomponent toxin LukElukD, J. Clin. Microbiol. 37: 4012-4019, 1999.

GRAVET, A.; COUPPIÉ, P.; MEUNIER, O.; CLYTI, E.; MOREAU, B.; PRADINAUD, R.; MONTEIL, H.; PREVOST, G. Staphylococcus aureus isolated in cases of impetigo produces both epidermolysin A or B and LukE-LukD in $78 \%$ of 131 retrospective and prospective cases. J Clin Microbiol. Dec;39(12):4349-56, 2001.

GREENE, C.; MCDEVITT, D.; FRANCOIS, P.; VAUDAUX, P.E.; LEW, D.P.; FOSTER, T.J. Adhesion properties of mutants of Staphylococcus aureus defective in fibronectin-binding proteins and studies on the expression of fnb genes. Mol Microbiol. Sep;17(6):1143-52, 1995.

HACKBARTH, C.J., KOCAGOZ, T., KOCAGOZ, S. \& CHAMBERS, H.F. Point mutations in Staphylococcus aureus PBP 2 gene affect penicillin-binding kinetics and are associated with resistance. Antimicrob Agents Chemother. 39, 103-106, 1995.

HAVERI, M.; TAPONEN, S.; VUOPIO-VARKILA, J.; SALMENLINNA, S.; PYORALA, S. Bacterial genotype affects the manifestation and persistence of bovine Staphylococcus aureus intramammary infection. J Clin Microbiol 43: 959-961, 2005.

HAVERI, M.; HOVINEN, M.; ROSLÖF, A.; PYÖRÄLÄ, S. Molecular types and genetic profiles of Staphylococcus aureus strains isolated from bovine intramammary infections and extramammary sites. J Clin Microbiol. Nov;46(11):3728-35, 2008. Epub 2008 Sep 17.

HELALI, N.; CARBONNE, A.; NAAS, T.; KERNEIS, S.; FRESCO, O.; GIOVANGRANDI, Y.; FORTINEAU, N.; NORDMANN, P.; ASTAGNEAU, P. Nosocomial outbreak of staphylococcal scalded skin syndrome in neonates: epidemiological investigation and control. J Hosp Infect. Oct;61(2):130-8, 2005.

HERRON-OLSON, L.; FITZGERALD, J.R.; MUSSER, J.M. \& KAPUR, V. Molecular correlates of host specialization in Staphylococcus aureus. PLOSONE 2, ed 120, 2007.

HERZER, C.M. Toxic shock syndrome: broadening the differential diagnosis. J Am Board Fam Pract. Mar-Apr;14(2):131-6, 2001.

HIROOKA, E.Y.; MÜLlER, E.E.; FREITAS, J.C.; VICENTE, E; YOSHIMOTO, Y.; BERGDOLL, M.S. Enterotoxigenicity of Staphylococcus intermedius of canine origin. Int J Food Microbiol., v. 7, p. 185-91, 1988.

HOLMES, A.; GANNER, M.; MC GUANE, S.; PITT, T.L.; COOKSON, B.D.; KEARNS, A.M. S. aureus isolates carrying Panton-Valentine leucocidin genes in England and Wales: Frequency, characterization and association with clinical disease. J. clin. Microbiol. v. 43, p. 2384-2390, 2005. 
HUIJSDENS, X.W.; VAN DIJKE, B.J.; SPALBURG, E.; VAN SANTEN-VERHEUVEL, M.G.; HECK, M.E.; PLUISTER, G.N.; VOSS, A.; WANNET, W.J.; DE NEELING, A.J. Community-acquired MRSA and pig-farming. Ann Clin Microbiol Antimicrob. 5:26, 2006.

HUSEBY, M.; SHI, K.; BROWN, C.K.; DIGRE, J.; MENGISTU, F.; SEO, K.S.; BOHACH, G.A.; SCHLIEVERT, P.M.; OHLENDORF, D.H.; EARHART, C.A. Structure and biological activities of beta toxin from Staphylococcus aureus. J Bacteriol. Dec;189(23):8719-26. Epub 2007 Sep 14, 2007.

HUY, Y.H. Foodborne disease handbook-diseases caused by bacteria. New York: Marcel Dekker; 1994.

ITO, T.; OKUMA, K.; MA, X.X.; YUZA,W.A.H.; HIRAMATSU, K. Insights on antibiotic resistance of Staphylococcus aureus from its whole genome: genomic island SCC. Drug Resist. Updat. V.6, p.41-52, 2003.

JARRAUD, S.; MOUGEL, C.; THIOULOUSE, J.; UNA, G.; MEUGNIER, H.; FOREY, F.; NESME, X.; ETIENNE, J.; VANDENESCH, F. Relationships between Staphylococcus aureus genetic background, virulence factors, agr groups (alleles), and human disease. Infect. Immun. 70:631-641, 2002.

JAY, J.M. Gastrenterite estafilocócica. In: JAY, JM. Microbiologia de Alimentos. 6 ed., Porto Alegre: Artmed, cap. 23, p. 471-489, 2005.

JEVONS, M.P. “Celbenin"-resistant staphylococci. Brazilian Medical Journal. v.1. p. 124-125 (1961) apud HIRAMATSU, K.; KATAYAMA, Y.; YUZAWA, H.; ITO, T. Molecualr genetics of methicillin-resistant Staphylococcus aureus. Int J Med Microbiol. v. 292, p. 67-74, 2002.

JI, G., BEAVIS, R., NOVICK, R.P. Bacterial interference caused by autoinducing peptide variants. Science 276, 2027-2030, 1997.

JONES, T.O.; WIENEKE, A.A. Staphylococcal toxic shock syndrome. Vet Rec, v.119, p.435, 1986.

JØRGENSEN, H.J.; MØRK, T.; CAUGANT, D.A.; KEARNS, A.; RØRVIK, L.M. Genetic variation among Staphylococcus aureus strains from Norwegian Bulk Milk. Applied on Environmental Microbiology. v. 71, n. 12, p. 8352-8361, 2005.

JUHÁSZ-KASZANYITZKY, E.; JÁNOSI, S.; SOMOGYI, P.; DÁN, A.; VAN DER GRAAFVAN BLOOIS, L.; VAN DUIJKEREN, E.; WAGENAAR, J.A. MRSA transmission between cows and humans. Emerging infectious Diseases, v. 13, n 4, 2007.

KALOREY, D.R.; SHANMUGAM, Y.; KURKURE, N.V.; CHOUSALKAR, K.K.; BARBUDDHE, S.B. PCR-based detection of genes encoding virulence determinants in Staphylococcus aureus from bovine subclinical mastitis cases. J Vet Sci. Jun;8(2):151-4, 2007.

KANEKO, J.; KIMURA, T.; KAWAKAMI, Y.; TOMITA, T.; KAMIO, Y. Panton-Valentine leukocidin genes in a phage-like particle isolated from mitomycin C-treated Staphylococcus aureus V8 (ATCC 49775). Biosci Bio-technol Biochem. 61:1960-2, 1997. 
KANEKO, J. \& KAMIO, Y. Bacterial two-component and hetero-heptameric pore-forming cytolytic toxins: structures, pore-forming mechanism, and organization of the genes, Biosci. Biotechnol. Biochem. 68: 981-1003, 2004.

KAPUR, V.; SISCHO, W. M.; GREER, R. S.; WHITTAM, T. S.; MUSSER. J. M. Molecular population genetic analysis of Staphylococcus aureus recovered from cows. J. Clin. Microbiol. 33:376-380, 1995.

KATEROV, V.E.; GOLUBKOV, V.I.; TOTOLIAN, A.A.; SHALEN, K.; ENSEN, L.; MIKULA. I.; SMOLA I. The cloning and expression of the gene for Staphylococcus aureus beta-hemolysin. Zh. Mikrobiol. Epidemiol. Immunobiol. 3 pp. 28-33, 1994.

KATSUDA, K., HATA, E., KOBAYASHI, H., KOHMOTO, M., KAWASHIMA, K., TSUNEMITSU, H., EGUCHI, M. Molecular typing of Staphylococcus aureus isolated from bovine mastitic milk on the basis of toxin genes and coagulase gene polymorphisms. Vet Microbiol. Feb 25;105(3-4):301-5, 2005. Epub 2005 Jan 16.

KENNY, K., REISER, R.F., BASTIDA-CORCUERA, F.D.; NORCROSS, N.L. Production of enterotoxins and toxic shock syndrome toxin by bovine mammary isolates of $S$. aureus. Journal of Clinical Microbiology v.31, p. 796-707, 1993.

KERRO DEGO, O.; VAN DIJK, J.E.; NEDERBRAGT, H. Factors involved in the early pathogenesis of bovine Staphylococcus aureus mastitis with emphasis on bacterial adhesion and invasion. A review. Vet Q. 24:181-198, 2002.

KESERU, J.S.; GAL, Z.; BARABAS, G.; BENKO, I. \& SZABO, I. Investigation of betalactamases in clinical isolates of Staphylococcus aureus for further explanation of borderline methicillin-resistance. Chemotherapy 51, 300-304, 2005.

KLOOS, W.E.; BANNERMAN, T.L. Staphylococcus and Micrococcus. In: MURRAY, P.R et al. (Eds.). Manual of clinical microbiology. Washington: American Society for Microbiology, p. 264-82, 1999.

KLOTZ, M.; OPPER, S.; HEEG, K.; ZIMMERMANN, S. Detection of S. aureus enterotoxins A to D by real-time fluorescence PCR assay. J Clin Microbiol. v. 41, p. 4683-4687, 2003.

KNAPP, C.C.; LUDWIG, M.D.; WASHINGTON, J.A.; CHAMBERS, H.F. Evaluation of Vitek GPS-SA card for testing of oxacillin against borderline-susceptible staphylococci that lack mec. $\mathbf{J}$ Clin Microbiol. Jul;34(7):1603-5, 1996.

KÖNIG, B.; PREVOST G.; KÖNIG W. Composition of staphylococcal bi-component toxins determines pathophysiological reactions, J. Med. Microbiol. 46, pp. 479-485, 1997.

KUMAR, R.; BHATIA, K.L. Lactoperoxidase activity in buffalo Milk and whey. In: World Buffalo Congress, 4, 1994, São Paulo, SP. Associação Brasileira de Criadores de Búfalos, p. 168-170, 1994.

KURODA, M.; T. OHTA, L UCHIYAMA, T. BABA, H. YUZAWA, L KOBAYASHI, L. CUI, A. OGUCHI, K. AOH, Y. NAGAI, J. LIAN, T. ITO, M. KANAMORI, H. MATSUMARU, A. MARUYAMA, H. MURAKAMI, A. HOSOYAMA, Y. MLZUTANI-UI, N.K. TAKAHASHI, T. 
SAWANO, R. INOUE, C KAITO, K. SEUMIZU, H. HIRAKAWA, S. KUHARA, S. GOTO, J. YABUZAM, M. KANEHISA, A. YAMASHITA, K. OSHIMA, K. FURUYA, C. YOSHINO, T. SHIBA, M. HATTORI, N. OGASAWARA, H. HAYASHI, AND K. HIRAMATSU. Whole genome sequencing of methicillin-resistant Staphylococcus aureus. Lancet 357:1225-1240, 2001.

KUYPERS, J.M. \& PROCTOR, R.A. Reduced adherence to traumatized rat heart valves by a lowfibronectin-binding mutant of Staphylococcus aureus. Infect, Immun. 57:2306-2312, 1989.

LANGONI, H. Anais do IV encontro de pesquisadores em mastites. FMVZ-UNESP. BotucatuSP, p. 8-17, 2007.

LARSEN, H.D.; HUDA, A.; ERIKSEN, N.H.; JENSEN, N.E. Differences between Danish bovine and human Staphylococcus aureus isolates in possession of superantigens.Veterinary Microbiology, Amsterdam, v. 76, p. 153-162, 2000.

LARSEN, H.D.; AARESTRUP, F.M.; JENSEN, N.E. Geographical variation in the presence of genes encoding superantigenic exotoxins and beta-hemolysin among Staphylococcus aureus isolated from bovine mastitis in Europe and USA. Vet Microbiol. Feb 26;85(1):61-7, 2002.

LASA, I. \& PENADÉS, J.R. Bap: a family of surface proteins involved in biofilm formation. Res Microbiol. Mar;157(2):99-107. Epub 2005 Dec 27, 2006.

LESKI, T.A. \& TOMASZ, A. Role of penicillin-binding protein 2 (PBP2) in the antibiotic susceptibility and cell wall cross-linking of Staphylococcus aureus: evidence for the cooperative functioning of PBP2, PBP4, and PBP2A. J Bacteriol 187, 1815-1824. 2005.

LIBERA, A.M.P.D. Anais do IV encontro de pesquisadores em mastites. FMVZ-UNESP. Botucatu-SP. p. 64-73, 2007.

LINA, G., PIEMONT, Y.; GODAIL-GAMOT, F.; BES, M.; PETER, M.O.; GAUDUCHON, V.; VANDENESCH, F. \& ETIENNE, J. Involvement of Panton-Valentine leukocidin-producing Staphylococcus aureus in primary skin infections and pneumonia. Clin. Infect. Dis. 29:1128-1132, 1999.

LINDSAY, J.A.; HOLDEN, M.T. Understanding the rise of the superbug: investigation of the evolution and genomic variation of Staphylococcus aureus. Fnct Integr Genomics. 6:186-201, 2006.

LISA, R.W.; PLANO, M.D. Staphylococcus aureus exfoliative toxins: How they cause disease. Journal of Investigative Dermatology, Baltimore, v. 122, p. 1070-1077, 2004

LOEFFLER, D.A. \& NORCROSS, N.L. Enzyme-linked immunosorbent assay for detection of milk immunoglobulins to leukocidin toxin of Staphylococcus aureus. Am. J. Vet. Res. 46:1728-1732, 1985.

LOEFFLER, A., BOAG, A.K., SUNG, J., LINDSAY, J.A., GUARDABASSI, L., DALSGAARD, A., SMITH, H., STEVENS, K.B. \& LLOYD, D.H. Prevalence of methicillin-resistant Staphylococcus aureus among staff and pets in a small animal referral hospital in the UK. J Antimicrob Chemother 56, 692-697, 2005. 
MARR, J. C.; LYON, J. D., ROBERSON, J. R., LUPHER, M., DAVIS, W.C.; BOHACH, G.A. Characterization of novel type $\mathrm{C}$ staphylococcal enterotoxins: biological and evolutionary implications. Infect Immun 61, 4254-4262, 1993.

MARRACK, P.; KAPPLER, J. The staphylococcal enterotoxins and their relatives. Science, v. 248, p.705-11, 1990.

MARSHALL, M.J., BOHACH, G.A.; BOEHM, D.F. Characterization of Staphylococcus aureus beta-toxin induced leukotoxicity. J. Nat. Toxins 9:125-138, 2000.

MASSIDDA, O., MONTANARI, M.P. \& VARALDO, P.E. Evidence for a methicillin-hydrolysing beta-lactamase in Staphylococcus aureus strains with borderline susceptibility to this drug. FEMS Microbiol Lett 71, 223-227, 1992.

MASSIDDA, O.; MONTANARI, M.P.; MINGOIA, M.; VARALDO, P.E. Cloning and expression of the penicillinase from a borderline methicillin-susceptible Staphylococcus aureus strain in Escherichia coli. FEMS Microbiol Lett. Aug 1;121(1):131, 1994.

MASSIDDA, O., MONTANARI, M.P., MINGOIA, M. \& VARALDO, P.E. Borderline methicillinsusceptible Staphylococcus aureus strains have more in common than reduced susceptibility to penicillinase-resistant penicillins. Antimicrob Agents Chemother. 40, 2769-2774, 1996.

MASSIDDA, O.; MINGOIA, M.; FADDA, D.; WHALEN, M.B.; MONTANARI, M.P.; VARALDO, P.E. Analysis of the beta-lactamase plasmid of borderline methicillin-susceptible Staphylococcus aureus: focus on bla complex genes and cadmium resistance determinants cadD and cadX. Plasmid. Mar;55(2):114-27, 2006. Epub 2005 Oct 17.

MATSUNAGA, T., KAMATA, S., KAKIICHI, N. AND UCCIDA, K. Characteristics of Staphylococcus aureus isolated from peracute, acute and chronic bovine mastitis. Journal if Veterinaiy Medicine Science v. 55, p. 297-300, 1993.

MCCORMICK, J. K.; YARWOOD, J.M. \& SCHLIEVERT, P. M. Toxic shock syndrome and bacterial superantigens: an update. Ann Rev Microbiol 55,77-104, 2001.

MCCULLOCH, J.A. Tese (Doutorado em análises clínicas). Avaliação da funcionalidade do locus accessory gene regulator (agr) em cepas de Staphylococcus aureus brasileiras com susceptibilidade reduzida aos glicopeptídeos. FCF/USP. São Paulo, 2006.

MCDOUGAL, L.K. \& THORNSBERRY, C. The role of beta-lactamase in staphylococcal resistance to penicillinase-resistant penicillins and cephalosporins. J Clin Microbiol 23, 832-839, 1986.

MCELROY, M.C.; CAIN, D.J.; TYRRELL, C.; FOSTER, T.J.; HASLETT, C. Increased virulence of a fibronectin-binding protein mutant of Staphylococcus aureus in a rat model of pneumonia. Infect. Immun. 70:3865-3873, 2002.

MELISH, M.E \& GLASGOW, L.A. The staphylococcal scalded skin syndrome: development of an experimental model. N. Engl. J. Med. v. 282, p. 1114-1119, 1970. 
MENZIES, P.I.; RAMANOON, S.Z. Mastitis of sheep and goats. Veterinary Clinics of North America: Food Animal Practice, v. 17, n. 2, p. 333-355, 2001.

MONTANARI, M.P.; TONIN, E.; BIAVASCO, F.; VARALDO, P.E. Further characterization of borderline methicillin-resistant Staphylococcus aureus and analysis of penicillin-binding proteins. Antimicrob Agents Chemother. May;34(5):911-3, 1990.

MOREILlON, P.; ENTENZA, J.M.; FRANCIOLI, P.; MCDEVITT, D.; FOSTER, T.J.; FRANCOIS, P.; VAUDAUX, P. Role of Staphylococcus aureus coagulase and clumping factor in pathogenesis of experimental endocarditis. Infect. Immun. 63:4738-4743, 1995.

MORINAGA, N., KAIHOU, Y.; NODA, M. Purification, cloning and characterization of variant LukE-LukD with strong leukocidal activity of staphylococcal bi-component leukotoxin family, Microbiol. Immunol. 47 p. 81-90, 2003.

MOUSSA, L.B.; WERNER, S.; COLIN, D.A. MOUREY, L.; PEDELACQ, J.D.; SAMAMA, J.P. SANNI, A.; MONTEIL H. AND PREVOST, G. Discoupling the $\mathrm{Ca}(2+)$-activation from the poreforming function of the bi-component Panton-Valentine leucocidin in human PMNs, FEBS Lett. 461 p. $280-286,1999$.

NADARAJAH, J., LEE, M.J.; LOUIE, L.; JACOB, L.; SIMOR, A.E.; LOUIE, M.; MCGAVIN, M.J. Identification of different clonal complexes and diverse amino acid substitutions in penicillinbinding protein 2 (PBP2) associated with borderline oxacillin resistance in Canadian Staphylococcus aureus isolates. J Med Microbiol. Dec;55(Pt 12):1675-83, 2006.

NICKERSON, S.C. Effect of cytokines on bovine mammary gland immunity. SAAS Bull Biochemistry Biotechnol, v. 4, p. 60-67, 1991.

NOTERMANS, S.; HEUVELMAN, K.J.; WERNSRDS, K. Synthetic enterotoxin B DNA probes for detection of enterotoxigenic Staphylococcus aureus strains. Appl Environ Microbiol., v. 54, p. 531-533, 1988.

NOVICK, R.P. Pathogenicity factors and their regulation, p. 392-407. In V. A. Fischetti, R.P. Novick, J. J. Ferretti, D.A. Portnoy, and J. I. Rood (ed.), Gram-positive pathogens. ASM Press, Washington, D.C, 2000.

OKUMA, K.; IWAKAWA, K.; TURNIDGE, J.D.; GRUBB, W.B.; BELL, J.M.; O`BRIEN, F.G.; COOMBS, G.W.; PEARMAN, J.W.; TENOVER, F.C.; KAPI, M.; TIENSASITORN, C.; ITO, T.; HIRAMATSU, K. Dissemination of new Methicillin-resistant Staphylococcus aureus clones in the community. J. Clin Microbiol. v. 40, n. 11, p. 4289-4294, 2002.

OPENSHAW, A.E., RACE, P.R.; MONZO, H.J.; VAZQUEZ-BOLAND, J.A.; BANFIELD, M.J. Crystal structure of SmcL, a bacterial neutral sphingomyelinase C from Listeria. J. Biol. Chem. 280:35011-35017, 2005. 
ORDEN, J.A, GOYACHE, J., HERNANDEZ, J., DOMENECH, A., SUAREZ, G. \& GOMEZ LUCIA, E. Detection of enterotoxins and TSST-1 secreted by Staphylococcus aureus isolated from ruminant mastitis. Comparison of ELISA and immunoblot. JAppl Bacteriol 72, 486-489, 1992.

PARRILO, J.E.: Pathogenetic mechanisms of septic shock. N. Engl J. M. v.329, p. 1427, 1993.

PATTI, J.M.; ALLEN, B.L.; MCGAVIN, M.J.; HÖÖK, M. MSCRAMM-mediated adherence of microorganisms to host tissues. Annu Rev Microbiol.;48:585-617, 1994.

PEACOCK, S.; MOON, C.; JUSTICE, A.; KANTZANOU, M.; STORY, L.; MACKIE, K.; O'NEILL, G.; DAY, N. Virulent combination of adhesin and toxin genes in natural populations of Staphylococcus aureus. Infect. Immun. 70:4987- 4996, 2002.

PFALLER, M.A. Chromosomal restriction fragment analisys by pulsed-field gel electrophoresis. In: Isemberg HD, editor. Clinical microbiology procedures handbook. Washington: American Society for Microbiology, 1993.

PINHO, M.G.; DE LENCASTRE, H. \& TOMASZ, A. An acquired and a native penicillin-binding protein cooperate in building the cell wall of drug-resistant staphylococci. Proc Natl Acad Sci U S A 98, 10886-10891, 2001a.

PINHO, M.G.; FILIPE, S.R.; DE LENCASTRE, H. \& TOMASZ, A. Complementation of the essential peptidoglycan transpeptidase function of penicillin-binding protein 2 (PBP2) by the drug resistance protein PBP2A in Staphylococcus aureus. J Bacteriol 183, 6525-6531, 2001b.

PREVOST, G.; JAULHAC, B.; PIEMONT, Y. DNA fingerprint by pulsed-field gel electrophoresis is more effective than ribotyping in distinguishing among methicillin-resistant Staphylococcus aureus isolates. J Clin Microbiol. v. 30(4) p. 967-973, 1992.

PREVOST, G. The Comprehensive Sourcebook of Bacterial Protein Toxins. In: J.H. Freer, Editor, Academic Press, London. p. 402-418, 1999.

PREVOST, G.; MOUREY, L.; COLIN D.A. AND MENESTRINA, G. Staphylococcal poreforming toxins. Curr. Top. Microbiol. Immunol. 257 p. 53-83, 2001.

PROJAN, S.J.; KORNBLUM, J.; KREISWIRTH, B.; MOGHAZEH, S.L. EISNER W. \& NOVICK, R.P. Nucleotide sequence: the beta-hemolysin gene of Staphylococcus aureus. Nucl. Acids Res. 17, p. 3305, 1989.

PROJAN, S.J. \& NOVICK, R.P. The molecular basis of pathogenesis. In The Staphylococci in Human Disease ed.Crossley, K.B. and Archer, G.L. p. 55-81. New York, NY: Churchill Livingstone, 1997.

PUGH, D.G. Clínica de ovinos e caprinos. São Paulo: Roca, p. 513, 2005.

QUE, Y.A.; FRANCOIS, P.; HAEHIGER, J.A.; ENTENZA, J.M.; VAUDAUX, P. \& MOREILLON, P. Reassessing the role of Staphylococcus aureus clumping factor and fibronectin-binding protein by expression in Lactococcus lactis. Infect. Immun. 69:6296-6302, 2001. 
RADOSTITIS, O.M.; BLOOD, D.C; GAY, C.C. Veterinary medicine. 8. ed. London: Bailliere Tindal, 2002.

RAINARD, P.; CORRALES, J.C.; BARRIO, M.B; COCHARD, T.; POUTREL, B. Leuco-toxic activities of Staphylococcus aureus strains isolated from cows, ewes, and goats with mastitis: importance of LukM/LukF-PV leukotoxin, Clin. Diagn. Lab. Immunol. 10: 272-277, 2003.

REDDY, K. \& ROSS, J.M. Shear Stress Prevents Fibronectin Binding Protein-Mediated Staphylococcus aureus Adhesion to Resting Endothelial Cells. Infection and Immunity, May, p. 3472-3475, v. 69, no 5, 2001.

REINOSO, E.; BETTERA, S.; FRIGERIO, C.; DIRENZO, M.; CALZOLARI, A.; BOGNI, C. RAPD-PCR analysis of Staphylococcus aureus strains isolated from bovine and human hosts. Microbiol Res 159: 245-255, 2004.

REINOSO, E.B.; EL-SAYED, A.; LÄMMLER, C.; BOGNI, C.; ZSCHÖCK, M. Genotyping of Staphylococcus aureus isolated from humans, bovine subclinical mastitis and food samples in Argentina. Microbiol Res. 163(3):314-22, 2008. Epub 2006 Aug 23.

ROBERSON, J.R.; FOX, L.K.; HANCOCK, D.D.; GAY, J.M.; BESSER, T.E. Ecology of Staphylococcus aureus isolated from various sites on dairy farms. J Dairy Sci. Nov;77(11):335464, 1994.

ROWLAND, S.J.; DYKE, K.G. Tn552, a novel transposable element from Staphylococcus aureus. Mol Microbiol. Jun;4(6):961-75, 1990.

SÁ, M.E.P; CUNHA, M.L.R.S.; ELIAS, A.O.; VICTÓRIA, C. Importância do Staphylococcus aureus nas mastites subclínicas: pesquisa de enterotoxinas e toxina do choque tóxico, e a relação com a contagem de células somáticas. Braz J vet Res anim Sci, v. 41, n.5, p.320-326, 2004.

SAKO, T.; TSUCHIDA, N. Nucleotide sequence of the staphylokinase gene from Staphylococcus aureus. Nucleic Acids Res. v. 11, p. 7679, 1983.

SAKOULAS, G.; ELIOPOULOS, G.M.; MOELLERING， R.C.J.R.; WENNERSTEN， C.; VENKATARAMAN, L.; NOVICK, R.P.; GOLD, H.S. Accessory gene regulator (agr) locus in geographically diverse Staphylococcus aureus isolates with reduced susceptibility to vancomycin. Antimicrob Agents Chemother. May;46(5):1492-502, 2002.

SAMBROOK, J.; FRITSCH, E.F.; MANIATIS, T. Molecular cloning: a laboratory manual, $2^{\text {nd }}$ ed., Vol 3, Appendix B, Cold Spring Harbor Laboratory Press, USA, 1989.

SANTOS, F.G.B.; MOTA, R.A.; SILVEIRA FILHO, S.; MOTA, V.; SOUZA, H.M.; OLIVEIRA, M.B.; JOHNER, J.M.Q.; LEAL, N.C.; ALMEIDA, A.M.P.; BALBINO, T.C.L. Tipagem molecular de Staphylococcus aureus isolados do leite de vacas com mastite subclínica e equipamentos de ordenha procedentes do estado de Pernambuco. Revista Napgama, São Paulo, v. 6, p. 19-23, 2003.

SANTOS, R.A.; MENDONÇA, C.L; AFONSO, J.A.B.; SIMAO, L.C.V. Aspectos clinicos e características do leite em ovelhas com mastite induzida experimentalmente com Staphylococcus aureus. Pesquisa Veterinária Brasileira. v. 27, n. 1, p. 6-12, 2007. 
SCHAD, E.M.; PAPAGEORGIOU, A.C.; SVENSSON, L.A.; ACHARYA, K.R. A structural and functional comparison of staphylococcal enterotoxins A and $\mathrm{C} 2$ reveals remarkable similarity and dissimilarity. J Mol Biol., v.269, p. 270-80, 1997.

SCHMIDT, H., \& HENSEL. M. Pathogenicity islands in bacterial pathogenesis. Clin. Microbiol. Rev. 17:14-56, 2004.

SCHUBERTH, H.J.; KRUEGER, C.; ZERBE, H.; BLCCKMANN, E.; LEIBOLD, W. Characterization of leukocytotoxic and superantigen-like factors produced by Staphylococcus aureus isolates from milk of cows with mastitis. Vet Microbiol 82: 187-199, 2001.

SEARS, P.M. \& MCCARTHY, K.K. Management and treatment of staphylococcal mastitis. Vet Clin North Am Food Anim Pract 19, 171-185, 2003.

SENFT, B.; MEYER, F.; HARTMANN, M.L. Die Bedeutung der Proteine des Strichkanalkeratins im Abwehrsystem der bovinen Milchdruse. Milchwissenschaft, v. 45, p. 295-298, 1990.

SHAFER, W.M.; IANDOLO, J.J. Chromosomal locus for staphylococcal enterotoxin B. Infect Immun., v. 20, p. 273-278, 1978.

SHALITA, Z; HERTMAN, I; SAND, S. Isolation and characterization of a plasmid involved with enterotoxin B production in Staphylococcus aureus. J Bacteriol., v. 129, p. 317-325, 1977.

SILVA, E.R.; BOECHAT, J.U.D.; MARTINS, J.C.D.; FERREIRA, W.P.B.; SIQUEIRA, A.P.; SILVA, N. Hemolysin production by Staphylococcus aureus species isolated from mastitic goat milk in Brazilian dairy herds. Small Ruminant Research, Amsterdam, v. 56, p. 271-275, 2005.

SKINNER S.; MURRAY M.; WALUS T.; KARLOWSKY J.A. Failure of cloxacillin in treatment of a patient with borderline oxacillin-resistant Staphylococcus aureus endocarditis. J Clin Microbiol. Mar;47(3):859-61, 2009. Epub 2008 Dec 30.

SMELTZER, M.S.; GILLASPY, A.F.; PRATT, F.L.J.; THAMES, M.D. \& IANDOLO, J.J. Prevalence and chromosomal map location of Staphylococcus aureus adhesin genes. Gene 196:249-259, 1997.

SMITH, M.C.; SHERMAN, D.M. Mammary gland and milk production. In.: SMITH, M.C. (Ed.). Goat Medicine. Philadelphia: Lea \& Febiger. p. 620, 1994.

SOL, J.; SAMPIMON, O.C; BARKEMA, H.W.; SCHUKKEN, Y.H. Factors associated with cure after therapy of clinical mastitis caused by Staphylococcus aureus. J Dairy Sci. Feb;83(2):278-84, 2000 .

SORDILLO, L.M. \& DALEY, M.J. Role of cytokims in the preventon and treatment of mastitis. In: MEYERS, M.J.; MURTAUGH, M.P. (Ed.). Cytokins in animals health and disease. New York: M. Dekker. P. 389-419, 1995. 
STAALI, L.; MONTEIL, H. \& COLIN, D.A .The staphylococcal pore-forming leukotoxins open $\mathrm{Ca} 2+$ channels in the membrane of human polymorphonuclear neutrophils, J. Membr. Biol. 162 p. 209-216, 1998.

STEPHAN, R.; ANNEMULLER, C.; HASSAN, A.A.; LAMMLER, C. Characterization of enterotoxigenic Staphylococcus aureus strains isolated from bovine mastitis in north-east Switzerland. Vet Microbiol 78, 373-382, 2001.

STOODLEY, P.; CARGO, R.; RUPP, C.J; WILSON, S.; KLAPPER, I. Biofilm material properties as related to shear-induced deformation and detachment phenomena. J Ind Microbiol Biotechnol. Dec;29(6):361-7, 2002.

STOODLEY, P.; SAUER, K.; DAVIES, D.G.; COSTERTON, J.W. Biofilms as complex differentiated communities. Annu Rev Microbiol. 56:187-209, 2002. Epub 2002 Jan 30.

STRUELENS, M.J.; DEPLANO, A.; GODARD, C.; MÃES, N.; SERRUYS, E. Epidemiologic typing and delineation of genetic relatedness of methicillin-resistant Staphylococcus aureus by macrorestriction analysis of genomic DNA by using pulsed-field gel electrophoresis. J Clin Microbiol. .v.30, p. 2599-2605, 1992.

STUTZMANN, P.; ENTENZA, J.M.; VAUDAUX, P.; FRANCIOLI, P.; GLAUSER, M.P.; MOREILLON. Study of Staphylococcus aureus pathogenic genes by transfer and expression in the less virulent organisms Streptococcus gordonii. Infect. Immun. 69: 657-664, 2001.

SUNG, J.M.; LLOYD, D.H.; LINDSAY, J.A. Staphylococcus aureus host specificity: comparative genomics of human versus animal isolates by multi-strain microarray. Microbiology. Jul;154(Pt 7):1949-59, 2008.

SUTRA, L. \& POUTREL, B. Virulence factors involved in the pathogen esis of bovine intramammary infections due to Staphylococcus aureus. J. Med. Microbiol. 40:79-89, 1994.

TAPONEN, S.; JANTUNEN, A.; PYÖRÄLÄ, E.; PYÖRÄLÄ, S. Efficacy of targeted 5-day combined parenteral and intramammary treatment of clinical mastitis caused by penicillinsusceptible or penicillin-resistant Staphylococcus aureus. Acta Vet Scand. 44(1-2):53-62, 2003.

TOLLERSRUD, T.; KENNY, K.; REITZ, A.J.R.; LEE, J.C. Genetic and serologic evaluation of capsule production by bovine mammary isolates of Staphylococcus aureus and other Staphylococcus spp. from Europe and the United States. J Clin Microbiol. Aug;38(8):2998-3003, 2000.

TORMO, M.A., KNECHT, E.; GOTZ, F., LASA, I. \& PENADES, J.R. Bap-dependent biofilm formation by pathogenic species of Staphylococcus: evidence of horizontal gene transfer? Microbiology 151, 2465-2475, 2005. 
TORRES, V., PISHCHANY, G.; HUMAYUU, M.; SCHNEEWIND, O.; SKAAR, E. Staphylococcus aureus IsdB is a hemoglobin receptor required for heme iron utilization. J. Bacteriol. 188:8421-8429, 2006.

TRABULSI, L.R. \& ALTERTHUM, F. Microbiologia. 4a ed., Atheneu, 2004.

TRISTAN, A.; YING, L.; BES, M.; ETIENNE, J.; VANDENESCH, F.; LINA, G. Use of multiplex PCR to identify Staphylococcus aureus adhesins involved in human hematogenous infections. J Clin Microbiol. Sep;41(9):4465-7, 2003.

UBEDA, C.; TORMO, M.A.; CUCARELlA, C.; TROTONDA, P.; FOSTER, T.J.; LASA, I.; PENADÉS, J.R. Sip, an integrase protein with excision, circularization and integration activities, defines a new family of mobile Staphylococcus aureus pathogenicity islands. Mol Microbiol. Jul;49(1):193-210, 2003.

VALLE, J., VADILLO, S.E., PIRIZ, S. \& GOMEZ-LUCIA, E. Toxic shock syndrome toxin one (TSST-1) production by staphylococci isolated from goats and presence of specific antibodies to TSST-1 in serum and milk. Applied and Environmental Microbiology. 57, 889-891, 1991.

VANCRAEYNEST, D.; HERMANS, K.; HAESEBROUCK, F. Genotypic and phenotypic screening of high and low virulence Staphylococcus aureus isolates from rabbits for biofilm formation and MSCRAMMs. Vet Microbiol. Nov 15;103(3-4):241-7, 2004.

VATH, G.M.; EARTHART, C.A.; MONIE, D.D.; LANDOLO, J.J.; SCHLIEVERT, P.M.; OHLENDORF, D.H. The crystal structure of esfoliative toxin B: a superantigen with enzymatic activity, Biochemistry, v. 38, p. 10239-10246, 1999.

VAUTOR, E.; ABADIE, G., PONT, A. \& THIERY, R. Evaluation of the presence of the bap gene in Staphylococcus aureus isolates recovered from human and animals species. Vet Microbiol 127, 407-411, 2008.

VAZ, A.K. Anais do IV encontro de pesquisadores em mastites. FMVZ-UNESP. Botucatu-SP, p. 38-44, 2007.

VUONG, C.; SAENZ, H.L.; GÖTZ, F.; OTTO, M. Impact of the agr quorum-sensing system on adherence to polystyrene in Staphylococcus aureus. J Infect Dis. Dec;182(6):1688-93, 2000. Epub 2000 Oct 13.

WALDRON, D.E \& LINDSAY, J.A. Saul: a novel lineage-specific type 1 restriction-modification system that blocks horizontal gene transfer into Staphylococcus aureus and between S. aureus isolates of different lineages. Bacteriol. 188, 5578-5585, 2006.

WALEV, I., WELLER, U.; STRAUCH, S.; FOSTER, T. \& BHAKDI, S. Selective killing of human monocytes and cytokine release provoked by sphingomyelinase (ß-toxin) of Staphylococcus aureus. Infect. Immun. 64:2974-2979, 1996. 
WANN, E.R.; GURUSIDDAPPA, S. HOOK, M. The fibronectin-binding MSCRAMM FnbpA of Staphylococcus aureus is a bifunctional protein that also binds to fibrinogen. J Biol Chem. May 5;275(18):13863-71, 2000.

WEESE, J. S., ARCHAMBAULT, M., WILLEY, B. M., HEARN, P., KREISWIRTH, B. N., SAIDSALIM, B., MCGEER, A., LIKHOSHVAY, Y., PRESCOTT, J.F. \& LOW, D.E Methicillin resistant Staphylococcus aureus in horses and horse personnel, 2000-2002. Emerg Infect Dis 11, 430-435, 2005.

WELLNITZ, O.; KERR, D.E. Cryopreserved bovine mammary cells to model epithelial response to infection. Vet Immunol Immunopathol. Oct;101(3-4):191-202, 2004.

YAMAZAKI, O.; YAMAGUCHI, T.; SUGAI, M.; CELLIER, C.C.; ARNAUD, F.; VANDENSCH, F.; ETIENNE, J.; LINA, G. Clinical manifestations of staphylococcal scalded skin syndrome dependo n serotypes of exfoliative toxins. J. Clin. Microbiol. v. 43, p. 1890-1893, 2005.

YARWOOD, J.M.; MCCORMICK, J.K.; PAUSTIAN, M.L.; ORWIN, P.M.; KAPUR, V.; SCHLIEVERT, P.M. Characterization and expression analysis of Staphylococcus aureus pathogenicity island 3. Implications for the evolution of staphylococcal pathogenicity islands. Journal of Biological Chemistry, Bethesda, v. 277, p. 13138-13147, 2002.

YARWOOD, J.M.; SCHLIEVERT, P.M. Quorum sensing in Staphylococcus infections. J Clin Invest. Dec;112(11):1620-5, 2003.

ZADOKS, R.N.; VAN LEEUWEN, W.B.; KREFT, D.; FOX, L.K.; BARKEMA, H.W.; SCHUKKEN, Y.H.; VAN BELKUM, A. Comparison of Staphylococcus aureus isolates from bovine and human skin, milking equipment and bovine milk by phage typing, pulsed-field gel electrophoresis and binary typing. Journal of Clinical Microbiology, Washington, v. 11, n. 40, p. 3894-3902, 2002.

ZECCONI, A.; HAHN, G. Staphylococcus aureus in raw milk and human health risk. Bulletin of the International Dairy Federation, Bruxelas, v. 345, p.15-18, 2000.

ZHANG, S.; IANDOLO, J.J; STEWART, G.C. The enterotoxin D plasmid of Staphylococcus aureus encodes a second enterotoxin (sej). FEMS Microbiology Letters, Amsterdam, v. 168, p. 227-233, 1998.

ZSCHÖCK, M., KLOPPERT, B., WOLTER, W., HAMANN, H.P. \& LÄMMLER, C. Patterns of enterotoxin genes seg, seh, sei and sej positive Staphylococcus aureus isolated from bovine mastitis. Vet Microbiol 108, 243-249, 2005. 


\section{Anexo}

\section{A - Soluções e Reagentes}

\section{Proteinase K}

Dissolver 100mg de proteinase K (GibcoBRL, Life Technologies, USA) em 10mM de Tris $\mathrm{HCl} \mathrm{pH} 7,5 ; 20 \mathrm{mM}$ de cloreto de cálcio e $50 \%$ de glicerol. Armazenar a $-20^{\circ} \mathrm{C}$.

\section{Lisostafina}

Solução estoque

Dissolver lmg de lisostafina em $1 \mathrm{ml}$ de tampão de acetato de sódio 20mM pH4,5. Armazenar a $-20^{\circ} \mathrm{C}$.

Solução de uso

Diluir a solução estoque 1:10 em tampão de acetato de sódio $20 \mathrm{mM} \mathrm{pH} \mathrm{4,5.}$

\section{Tampão EC}

Tris $6 \mathrm{mM}$

1,5ml de Tris $1 \mathrm{M}$ pH 8,0

EDTA 0,1M

1,5 mldeTris $1 \mathrm{M}$ pH 7,0

5,0ml de EDTA 0,5M pH 8,0

$\mathrm{NaCl} 1 \mathrm{M}$ 5,0ml de EDTA 0,5M pH 7,0

Brij58 0,5\% $29,22 \mathrm{~g}$

Desoxicolato de sódio $0,2 \%$

$2,5 \mathrm{~g}$

Sarkosyl 0,5\% (N-Laurilsarcosina, sal sódico) $\quad 2,5 \mathrm{~g}$

Volume final: $500 \mathrm{ml}$ com água destilada deionizada.

pH final 7,5.

Esterilização por fíltração. 


\section{Tampão ES}

EDTA 0,4M, pH 9,3

40,0ml de EDTA 625mM pH 9,3

Sarkosyl 1\%

$10,0 \mathrm{ml}$ de sarkosyl a $5 \%$

Preparar no momento do uso.

\section{Tampão CHEF-TE}

Tris $0,1 \mathrm{M} \mathrm{pH} \mathrm{7,5}$

2,5ml de Tris $1 \mathrm{M} \mathrm{pH} \mathrm{8,0}$

EDTA 0,1M pH 7,5

2,5mlde Tris $1 \mathrm{M} \mathrm{pH7,0}$

5,0ml de EDTA 0,5M pH 8,0

5,0ml de EDTA 0,5M pH 7,0

Volume final: $50 \mathrm{ml}$ com água destilada deionizada.

Esterilização a $121^{\circ} \mathrm{C}$ por 15 minutos.

\section{Tampão DNS}

Tris $0,1 \mathrm{M} \mathrm{pH} \mathrm{8,0}$

Cloreto de magnésio 5mM 5,0ml de Tris $1 \mathrm{M} \mathrm{pH} \mathrm{8,0}$

$0,25 \mathrm{ml}$ de cloreto de magnésio $1 \mathrm{M}$

Volume final: 50ml com água destilada deionizada estéril.

Preparar no momento do uso.

\section{Agarose de baixo ponto de fusão a $2 \%$}

Agarose de baixo ponto de fusão

Água destilada deionizada

$2 \mathrm{~g}$

$100 \mathrm{ml}$

Dissolver a agarose em água destilada deionizada em banho de água fervente.

Esterilização a $121^{\circ} \mathrm{C}$ por 15 minutos. 


\section{Tampão Tris-Borato-EDTA (TBE)}

TBE concentrado

Tris base

$121, \lg$

Ácido bórico

$61,8 \mathrm{~g}$

EDTA

$3,7 \mathrm{~g}$

Volume final: 1000ml com água destilada deionizada.

Esterilização a $121^{\circ} \mathrm{C}$ por 15 minutos.

\section{TBE $0,5 X$}

TBE 10x

$50 \mathrm{ml}$

Água destilada deionizada

$950 \mathrm{ml}$

Preparar no momento do uso. 